Prepared in cooperation with the City of Wichita

Regression Relations and Long-Term Water-0uality Constituent Concentrations, Loads, Yields, and Trends in the North Fork Ninnescah River, South-Central Kansas, 1999-2019

Scientific Investigations Report $2021=5006$ 
Cover. Photograph showing North Fork Ninnescah River downstream from the continuous waterquality monitor installation, taken at the North Fork Ninnescah River above Cheney Reservoir (U.S. Geological Survey [USGS] site 07144780) on July 8, 2020, by David Eason (USGS hydrologic technician).

Back cover. Photograph showing sandy channel and streamflow conditions at 150 cubic feet per second upstream from the continuous water-quality monitor installation, taken at the North Fork Ninnescah River above Cheney Reservoir (USGS site 07144780) on November 26, 2018, by USGS personnel. 


\section{Regression Relations and Long-Term Water-Quality Constituent Concentrations, Loads, Yields, and Trends in the North Fork Ninnescah River, South-Central Kansas, 1999-2019}

By Ariele R. Kramer, Brian J. Klager, Mandy L. Stone, and Patrick J. Eslick-Huff

Prepared in cooperation with the City of Wichita

Scientific Investigations Report 2021-5006 


\section{U.S. Geological Survey, Reston, Virginia: 2021}

For more information on the USGS - the Federal source for science about the Earth, its natural and living resources, natural hazards, and the environment—visit https://www.usgs.gov or call 1-888-ASK-USGS.

For an overview of USGS information products, including maps, imagery, and publications, visit https://store.usgs.gov/.

Any use of trade, firm, or product names is for descriptive purposes only and does not imply endorsement by the U.S. Government.

Although this information product, for the most part, is in the public domain, it also may contain copyrighted materials as noted in the text. Permission to reproduce copyrighted items must be secured from the copyright owner.

Suggested citation:

Kramer, A.R., Klager, B.J., Stone, M.L., and Eslick-Huff, P.J., 2021, Regression relations and long-term water-quality constituent concentrations, loads, yields, and trends in the North Fork Ninnescah River, south-central Kansas, 1999-2019: U.S. Geological Survey Scientific Investigations Report 2021-5006, 51 p., https://doi.org/10.3133/ sir20215006.

Associated data for this publication: U.S. Geological Survey, 2020, USGS water data for the Nation: U.S. Geological Survey National Water Information System database, https://doi.org/10.5066/F7P55KJN.

ISSN 2328-0328 (online) 


\section{Acknowledgments}

The authors thank Mike Jacobs, Brooke Bailey, Shawn Maloney, and Scott Macey of the City of Wichita for technical assistance. The authors also thank Terryl Pajor, Vernon Strasser, and the laboratory staff at the City of Wichita Municipal Water and Wastewater Laboratory for laboratory analyses.

The authors thank the U.S. Geological Survey staff who assisted with data collection, analysis, and interpretation, including Jennifer Graham, Trudy Bennett, Thomas Williams, Barbara Dague, Carlen Collins, John Rosendale, David Eason, and Diana Restrepo-Osorio. Karen Ryberg and Liam Schenk of the U.S. Geological Survey provided helpful reviews that contributed to the technical clarity of this report. 



\section{Contents}

Acknowledgments ……...................................................................................................................

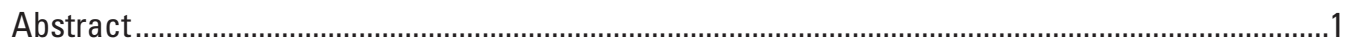

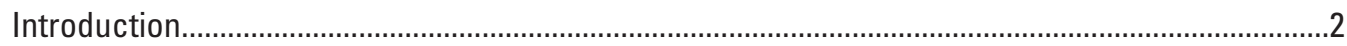

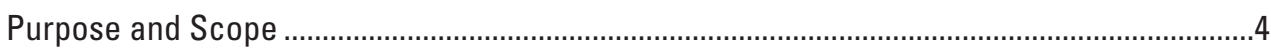

Description of Study Area and Background Information........................................................

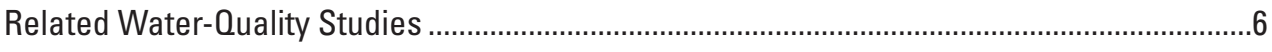

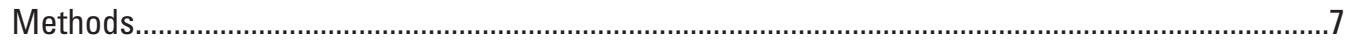

Continuous Water-Quality Monitoring....................................................................................

Discrete Water-Quality Sampling................................................................................................

Quality Assurance and Quality Control .............................................................................

Development of Regression Models to Compute Constituent Concentrations ........................13

Calculation of Annual Constituent Loads and Yields and Streamflow-Separation Point .......13

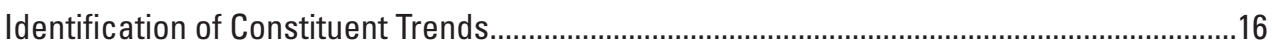

Regression Relations and Water-Quality Trend Results ...........................................................18

Continuously Monitored Water-Quality Variables.................................................................18

Regression Models for Selected Constituents ..................................................................19

Total Suspended Solids and Suspended-Sediment Concentration................................19

Nutrients and Carbon ................................................................................................

Computed Constituent Concentrations, Fluxes, and Yields ..................................................21

Comparison of Total Suspended Solids, Nitrate, and Total Phosphorus

Concentrations with Cheney Reservoir Task Force Goals ..................................25

Weighted Regressions on Time, Discharge, and Season Models...........................................28

Computed Load Comparisons ......................................................................................28

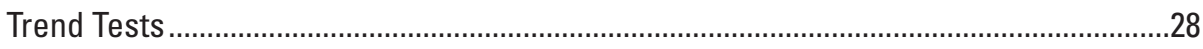

Comparison of Results with Long-Term Water-Quality Goals ..............................................40

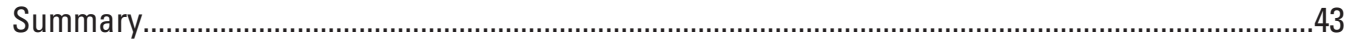

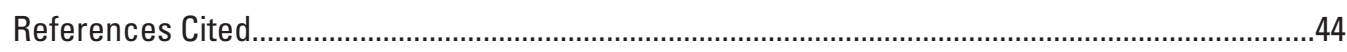

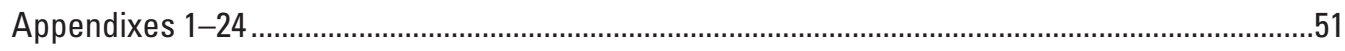

\section{Figures}

1. Map showing location of continuous real-time water-quality monitoring site and land use in the Cheney Reservoir drainage basin, south-central Kansas

2. Graph showing annual precipitation totals, extreme event precipitation totals, and counts of extreme precipitation days for Global Historical Climatology Network station Hutchinson 10 SW, in Hutchinson, Kansas.

3. Graphs showing duration curves for hourly and discretely measured constituents at the North Fork Ninnescah River upstream from Cheney Reservoir, south-central Kansas, 1999 through 2019.

4. Graphs showing computed annual loads for constituents at the North Fork Ninnescah River upstream from Cheney Reservoir, south-central Kansas, 1999 through 2019 
5. Boxplots showing model-computed daily and sampled concentrations for constituents at the North Fork Ninnescah River upstream from Cheney

Reservoir, south-central Kansas.

6. Boxplots showing annual mean computed values during base-flow and runoff streamflow conditions at the North Fork Ninnescah River upstream from Cheney Reservoir, south-central Kansas, 1999 through 2019

7. Graphs showing model-computed load comparisons between Weighted Regressions on Time, Discharge, and Season model and linear regression developed models, 1999 through 2019...

8. Graphs showing annual mean concentrations with flow-normalized concentration trend and 90-percent confidence interval for constituents at the North Fork Ninnescah River upstream from Cheney Reservoir, south-central Kansas, 1999 through 2019.

9. Graphs showing annual mean fluxes with flow-normalized flux trend and 90-percent confidence interval for constituents at the North Fork Ninnescah River upstream from Cheney Reservoir, south-central Kansas, 1999 through 2019 .37

\section{Tables}

1. Cheney Reservoir Task Force mean stream water-quality goals for total suspended solids, dissolved nitrate as nitrogen, and total phosphorus concentrations in Cheney Reservoir drainage basin streams during base-flow, runoff, and long-term streamflow conditions

2. Summary statistics for variables measured continuously at the North Fork Ninnescah River upstream from Cheney Reservoir, south-central Kansas, January 1, 1999, through December 31, 2019.

3. Summary of quality-control replicate results for all discretely collected replicate data, 1999 through 2017

4. Summary of quality-control replicate results for Wichita Municipal Water and Wastewater Laboratory discretely collected replicate data, 1999 through 2017

5. Summary of quality-control replicate results for discretely collected data comparing Wichita Municipal Water and Wastewater Laboratory and National Water Quality Laboratory results, 1999 through 2017.

6. Updated and new regression models and summary statistics for continuous concentration computations for the North Fork Ninnescah River upstream from Cheney Reservoir, south-central Kansas, model validation period 1999 through 2017

7. Summary statistics for discretely collected constituents at the North Fork Ninnescah River upstream from Cheney Reservoir, south-central Kansas, January 1, 1999, through September 30, 2017

8. Summary of daily statistics for selected water-quality constituents computed with updated and newly developed regression models and continuously measured physicochemical constituents at the North Fork Ninnescah River upstream from Cheney Reservoir, south-central Kansas, 1999 through 2019.

9. Computed annual loads and yields for selected constituents at the North Fork Ninnescah River upstream from Cheney Reservoir, south-central Kansas, 1999 through 2019

10. Summary statistics for selected water-quality constituents computed with updated regression models and daily mean values of continuously measured 
physical properties at the North Fork Ninnescah River upstream from Cheney

Reservoir, south-central Kansas, 1999 through 2019.

11. Computed concentrations and flow-normalized concentrations for selected water-quality constituents at the North Fork Ninnescah River upstream from Cheney Reservoir, south-central Kansas, 1999 through 2019

12. Computed constituent flux and flow-normalized flux for selected water-quality constituents at the North Fork Ninnescah River upstream from Cheney Reservoir, south-central Kansas, 1999 through 2019.

13. Definitions for descriptive statements of likelihood of trends for Weighted Regressions on Time, Discharge, and Season bootstrap test as a function of the posterior mean estimate of the probability of an upward trend...

14. Summary of trend likelihood results of Weighted Regressions on Time, Discharge, and Season bootstrap tests for trends in flow-normalized concentrations and fluxes at the North Fork Ninnescah River upstream from Cheney Reservoir, south-central Kansas, 1999 through September 2017.

15. Trend changes for selected water-quality constituents at the North Fork Ninnescah River upstream from Cheney Reservoir, south-central Kansas, 1999 through 2019

\section{Conversion Factors}

U.S. customary units to International System of Units

\begin{tabular}{|c|c|c|}
\hline Multiply & By & To obtain \\
\hline \multicolumn{3}{|c|}{ Length } \\
\hline inch (in.) & 2.54 & centimeter $(\mathrm{cm})$ \\
\hline inch (in.) & 25.4 & millimeter $(\mathrm{mm})$ \\
\hline foot $(\mathrm{ft})$ & 0.3048 & meter $(\mathrm{m})$ \\
\hline mile (mi) & 1.609 & kilometer $(\mathrm{km})$ \\
\hline \multicolumn{3}{|c|}{ Area } \\
\hline acre & 4,047 & square meter $\left(\mathrm{m}^{2}\right)$ \\
\hline acre & 0.4047 & hectare (ha) \\
\hline acre & 0.4047 & square hectometer $\left(\mathrm{hm}^{2}\right)$ \\
\hline acre & 0.004047 & square kilometer $\left(\mathrm{km}^{2}\right)$ \\
\hline square mile $\left(\mathrm{mi}^{2}\right)$ & 259.0 & hectare (ha) \\
\hline square mile $\left(\mathrm{mi}^{2}\right)$ & 2.590 & square kilometer $\left(\mathrm{km}^{2}\right)$ \\
\hline \multicolumn{3}{|c|}{ Volume } \\
\hline acre-foot (acre-ft) & 1,233 & cubic meter $\left(\mathrm{m}^{3}\right)$ \\
\hline acre-foot (acre-ft) & 0.001233 & cubic hectometer $\left(\mathrm{hm}^{3}\right)$ \\
\hline \multicolumn{3}{|c|}{ Flow rate } \\
\hline acre-foot per year (acre-ft/yr) & 1,233 & cubic meter per year $\left(\mathrm{m}^{3} / \mathrm{yr}\right)$ \\
\hline acre-foot per year (acre-ft/yr) & 0.001233 & cubic hectometer per year $\left(\mathrm{hm}^{3} / \mathrm{yr}\right)$ \\
\hline cubic foot per second ( $\left.\mathrm{ft}^{3} / \mathrm{s}\right)$ & 0.02832 & cubic meter per second $\left(\mathrm{m}^{3} / \mathrm{s}\right)$ \\
\hline \multicolumn{3}{|c|}{ Mass } \\
\hline pound, avoirdupois (lb) & 0.4536 & kilogram (kg) \\
\hline
\end{tabular}




\begin{tabular}{lcl}
\hline \multicolumn{1}{c}{ Multiply } & By & \multicolumn{1}{c}{ To obtain } \\
\hline ton, short $(2,000 \mathrm{lb})$ & 0.9072 & metric ton $(\mathrm{t})$ \\
\hline \multicolumn{2}{c}{ Pressure } & \\
\hline pound per square mile $\left(\mathrm{lb} / \mathrm{mi}^{2}\right)$ & 1.717 & kilopascal $(\mathrm{kPa})$ \\
\hline
\end{tabular}

Temperature in degrees Celsius $\left({ }^{\circ} \mathrm{C}\right)$ may be converted to degrees Fahrenheit $\left({ }^{\circ} \mathrm{F}\right)$ as follows: ${ }^{\circ} \mathrm{F}=\left(1.8 \times{ }^{\circ} \mathrm{C}\right)+32$.

Temperature in degrees Fahrenheit $\left({ }^{\circ} \mathrm{F}\right)$ may be converted to degrees Celsius $\left({ }^{\circ} \mathrm{C}\right)$ as follows: ${ }^{\circ} \mathrm{C}=\left({ }^{\circ} \mathrm{F}-32\right) / 1.8$.

\section{Datum}

Vertical coordinate information is referenced to the North American Vertical Datum of 1988 (NAVD 88).

Horizontal coordinate information is referenced to the North American Datum of 1983 (NAD 83). Elevation, as used in this report, refers to distance above the vertical datum.

\section{Supplemental Information}

Specific conductance is given in microsiemens per centimeter at 25 degrees Celsius $(\mu \mathrm{S} / \mathrm{cm}$ at $\left.25^{\circ} \mathrm{C}\right)$.

Concentrations of chemical constituents in water are given in milligrams per liter (mg/L).

Concentrations of nitrogen species in water are given in milligrams per liter as nitrogen.

Concentrations of phosphorus species in water are given in milligrams per liter as phosphorus. 


\section{Abbreviations}

$\begin{array}{ll}\text { BMP } & \text { best management practice } \\ \text { CRP } & \text { Conservation Reserve Program } \\ \text { CRTF } & \text { Cheney Reservoir Task Force } \\ \text { EDS } & \text { Extended Deployment System }\end{array}$

EGRET Exploration and Graphics for RivEr Trends

EGRETci Exploration and Graphics for RivEr Trends Confidence Intervals

EPA U.S. Environmental Protection Agency

FNU formazin nephelometric unit

GHCN Global Historical Climatology Network

KDHE Kansas Department of Health and Environment

MCL maximum contaminant level

MIB 2-methylisoborneol

NWOL National Water Quality Laboratory

OP orthophosphate

OC quality control

RPD relative percentage difference

SSC suspended-sediment concentration

TMDL total maximum daily load

TOC total organic carbon

TP total phosphorus

TSS total suspended solids

USGS U.S. Geological Survey

WBT Weighted Regressions on Time, Discharge, and Season bootstrap test

WMWWL Wichita Municipal Water and Wastewater Laboratory

WRTDS Weighted Regressions on Time, Discharge, and Season 



\title{
Regression Relations and Long-Term Water-Quality Constituent Concentrations, Loads, Yields, and Trends in the North Fork Ninnescah River, South-Central Kansas, 1999-2019
}

\author{
By Ariele R. Kramer, Brian J. Klager, Mandy L. Stone, and Patrick J. Eslick-Huff
}

\section{Abstract}

Cheney Reservoir, in south-central Kansas, is the primary water supply for the city of Wichita, Kansas. The North Fork Ninnescah River is the largest tributary to Cheney Reservoir and contributes about 70 percent of the inflow. The U.S. Geological Survey, in cooperation with the City of Wichita, has been continuously monitoring water quality (including water temperature, specific conductance, $\mathrm{pH}$, dissolved oxygen, and turbidity) on the North Fork Ninnescah River upstream from Cheney Reservoir (U.S. Geological Survey site 07144780) since November 1998. Continued data collection would be beneficial to update and describe changing water-quality conditions in the drainage basin and in the reservoir over time.

Regression models were developed to describe relations between discretely measured constituent concentrations and continuously measured physical properties. The models updated in this report include total suspended solids (TSS), suspended-sediment concentration (SSC), nitrate plus nitrite, nitrate, orthophosphate (OP), total phosphorus (TP), and total organic carbon (TOC).

Daily computed concentrations for TSS, TP, and nitrate plus nitrite during 1999-2019 were compared with Cheney Reservoir Task Force (CRTF) goals for base-flow and runoff conditions. CRTF goals for base-flow concentrations were exceeded more frequently (70 to 99.9 percent of the time) than runoff goals (0 to 11 percent of the time). Except for 2012, annual mean TSS concentrations exceeded the base-flow goal every year. Nitrate plus nitrite and TP annual mean concentrations exceeded the base-flow goals every year. TSS and nitrate plus nitrite annual mean concentrations during runoff conditions never exceeded the CRTF runoff goal. TP annual mean concentrations during runoff conditions only exceeded the CRTF runoff goal during 2002.

Sedimentation is progressively reducing the storage capacity of Cheney Reservoir. During 1999-2019, 55 percent of the computed suspended-sediment load was transported during the top 1 percent of loading days (76 days); 22 percent of the total load was transported in the top 10 loading days, indicating that substantial parts of suspended-sediment loads continue to be delivered during disproportionately small periods in Cheney Reservoir. Successful sediment management efforts necessitate reduction techniques that account for these large load events.

Flow-normalized concentrations and fluxes were computed during 1999 through 2019 using Weighted Regressions on Time, Discharge, and Season (WRTDS) statistical models and WRTDS bootstrap tests. Flow-normalized concentrations of TSS, SSC, OP, TP, and TOC had upward trend probabilities; conversely, nitrate plus nitrite had a downward trend. Flownormalized fluxes for OP, TP, and TOC had an upward trend. No discernible patterns were identified for flow-normalized flux of TSS or suspended sediment. Nitrate plus nitrite flownormalized flux indicated a downward trend.

Flow-normalized concentrations for TSS were less than the CRTF long-term goal of 100 milligrams per liter $(\mathrm{mg} / \mathrm{L})$, but the upward trend indicated the long-term goal may be exceeded if no changes are made. Flow-normalized TP concentrations exceeded the CRTF long-term goal $(0.1 \mathrm{mg} / \mathrm{L})$ and were assigned a very likely upward trend. Flow-normalized nitrate plus nitrite concentrations exceeded the CRTF longterm goal of $1.2 \mathrm{mg} / \mathrm{L}$ during the beginning of the study period, then were less than the CRTF goal for the remainder of the study; however, during 2010-19 flow-normalized concentrations increased by 6 percent.

Linking water-quality changes to causal factors requires consistent monitoring before, during, and after changes; this presents challenges related to length and frequency of data collection and available concomitant land-use and conservation practice data. As such, attribution of water-quality trends to land-use changes or conservation practices was not possible for this study because of a lack of land-use and conservation practice data. Additionally, because precipitation frequency and intensity are projected to continue to increase in the Great Plains region, accounting for extreme episodic events may be an important consideration in future sediment and nutrient load reduction plans. 


\section{Introduction}

Cheney Reservoir (fig. 1), in south-central Kansas, was constructed by the Bureau of Reclamation between 1962 and 1965. The primary purpose of Cheney Reservoir is to provide the city of Wichita, Kansas, with a reliable municipal water supply, downstream flood control, wildlife habitat, and recreation (Bureau of Reclamation, 2016). About 70 percent of Wichita's municipal water supply came from Cheney Reservoir during 1995 through 2013 (Hansen and others, 2014). Water-supply needs and reliance on Cheney Reservoir will continue to increase with ongoing population growth and urban development. Source-water protection is essential to preserving water-quality conditions and ensuring safe and reliable drinking-water supplies in the future.

Cheney Reservoir has a maximum depth of 41 feet (ft), a mean depth of $16.8 \mathrm{ft}$, and a surface area of about 15.5 square miles $\left(\mathrm{mi}^{2}\right)$ at a pool elevation of $1,421 \mathrm{ft}$ above the North American Vertical Datum of 1988 (Kansas Biological Survey, 2012). Thermal and chemical stratification rarely occur in Cheney Reservoir primarily because of the fairly shallow depths and persistent winds (Smith and others, 2002). Cheney Reservoir is eutrophic, and algal growth is predominantly light limited because of sediment resuspension (Smith and others, 2002; Christensen and others, 2006; Graham and

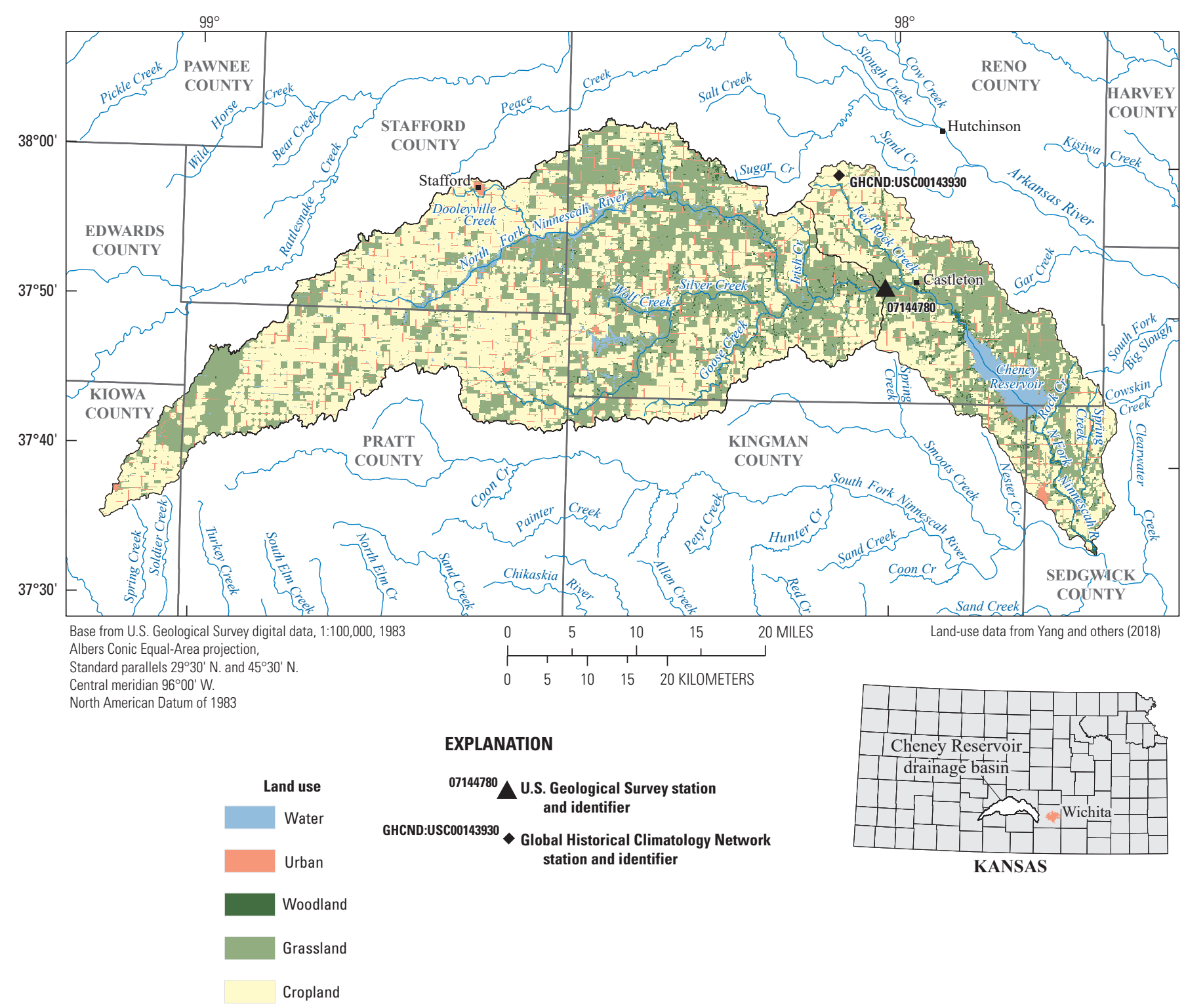

Figure 1. Location of continuous real-time water-quality monitoring site and land use in the Cheney Reservoir drainage basin, south-central Kansas. 
others, 2017). Cheney Reservoir nutrient ratios also indicate the reservoir has been either nitrogen limited or colimited by phosphorus and nitrogen (Kansas Department of Health and Environment, 2015b).

Cheney Reservoir has had persistent cyanobacterial blooms since 1990 that have resulted in increased treatment costs and decreased recreational use (Christensen and others, 2006; Kansas Department of Health and Environment, 2016). Cyanobacterial blooms can be harmful and may result in large concentrations of toxins and taste-and-odor causing compounds. Toxins and taste-and-odor causing compounds are a public health concern and may cause substantial economic effects, especially in lakes, reservoirs, and rivers that are used for drinking-water supply and recreation (Graham and others, 2008). Taste-and-odor occurrences are a concern to drinking-water suppliers because of customer dissatisfaction with unpalatable drinking water and increased treatment costs to remove taste-and-odor causing compounds (Taylor and others, 2005). Excessive nutrients also may cause cyanobacterial blooms. Sedimentation decreases reservoir life, may have a negative effect on benthic organisms, and creates lower light conditions (Graham and others, 2008). Sediment and nutrient transport reduction may ameliorate taste-and-odor problems in Cheney Reservoir by decreasing cyanobacterial abundance.

Cyanobacterial blooms in Cheney Reservoir during 1990 and 1991 caused severe taste-and-odor events and prompted the formation of the Cheney Reservoir Task Force (CRTF) in 1992. The CRTF consisted of members of the Reno and Sedgwick County Conservation Districts; Reno County Health Department; Wichita Water and Sewer Department; and other local, State, and Federal agencies. The CRTF identified nutrients and sediment as primary pollutants of concern in the Cheney Reservoir drainage basin because of their effects on water quality and quantity and their relation to cyanobacterial blooms. The CRTF prepared a water-quality plan to abate the transport of total suspended solids (TSS), nutrients, and pesticides into the reservoir (Cheney Reservoir Task Force, 1994).

The CRTF identified TSS and total phosphorus (TP) as primary pollutants of concern and established stream waterquality goals for TSS, nitrate, and TP during base-flow, runoff, and long-term streamflow conditions (table 1; Cheney Reservoir Task Force, 1994). TP and TSS concentration goals were established to reduce pollution and extend the life of
Cheney Reservoir from 130 to 200 years (Cheney Reservoir Task Force, 1994). To achieve these goals, about 1,500 contracts were established for the implementation of best management practices (BMPs) in the Cheney Reservoir drainage basin and Conservation Reserve Program (CRP) land increased by about 20,475 acres (Stone and others, 2013a).

The Kansas Department of Health and Environment (KDHE) defined designated uses for several streams within the Cheney Reservoir drainage basin (fig. 1; Kansas Department of Health and Environment, 2018). Domestic water supply, food procurement (obtaining edible aquatic life for human consumption), groundwater recharge, industrial water supply, irrigation, and livestock watering are designated uses for parts of the North Fork Ninnescah River, Red Rock Creek, and Silver Creek. Food procurement, groundwater recharge, irrigation, and livestock watering are designated uses for Dooleyville Creek and Goose Creek. Domestic water supply, groundwater recharge, industrial water supply, irrigation, and livestock watering are designated uses for Rock Creek, Spring Creek, and Wolf Creek (fig. 1).

KDHE has listed Cheney Reservoir and one stream in the drainage basin as impaired waterways under section 303(d) of the 1972 Clean Water Act (Kansas Department of Health and Environment, 2018). In the North Fork Ninnescah River near Castleton, Kans., $\mathrm{pH}$ is listed as an impairment for aquatic life. In Cheney Reservoir, siltation is listed as an impairment to water supply, and eutrophication and $\mathrm{pH}$ are listed as impairments to aquatic life. The Cheney Reservoir total maximum daily load (TMDL) allocation for sediment is a 10-percent reduction (Kansas Department of Health and Environment, 2000). The phase II Cheney Lake TMDL for $\mathrm{TP}$ is 40,184 pounds per year (about 20 tons per year; Kansas Department of Health and Environment, 2015b).

The "Cheney Lake WRAPs—9 Element Watershed Plan Summary" lists BMPs based on local acceptance and adoption rate. This summary includes buffers, no-till agriculture encouragement, retention of CRP contracts, cropland to grass conversion, streambank stabilization, reduced tillage for sediment reduction and buffers, nutrient management plan preparation, terraces and grassed waterways, fertilizer/manure incorporation, and relocation of feeding operations and sites for phosphorus reduction (Kansas Department of Health and Environment, 2011).

Table 1. Cheney Reservoir Task Force mean stream water-quality goals for total suspended solids, dissolved nitrate as nitrogen, and total phosphorus concentrations in Cheney Reservoir drainage basin streams during base-flow, runoff, and long-term streamflow conditions (Cheney Reservoir Task Force, 1994).

\begin{tabular}{lccc}
\hline \multirow{2}{*}{ Water-quality constituent } & \multicolumn{2}{c}{ Mean water-quality goal (milligrams per liter) } \\
\cline { 2 - 4 } & Base flow & Runoff & Long term \\
\hline Total suspended solids & 20 & 550 & 100 \\
Dissolved nitrate as nitrogen & 0.25 & 6.60 & 1.20 \\
Total phosphorus & 0.05 & 0.40 & 0.10 \\
\hline
\end{tabular}


The U.S. Geological Survey (USGS), in cooperation with the City of Wichita, has continuously monitored water quality at the North Fork Ninnescah River upstream from Cheney Reservoir (USGS site 07144780) (hereafter referred to as the "inflow site") since November 1998 (fig. 1). Streamflow has been measured continuously at the inflow site since July 1965. Water-quality monitoring at the inflow site provides hourly measures of water temperature, specific conductance, $\mathrm{pH}$, dissolved oxygen, and turbidity. Numerous discrete water-quality samples (about 100) have been collected at the inflow site and have been used to develop regression models establishing relations between continuously monitored water-quality physicochemical parameters and water-quality constituents of interest that are not monitored continuously. Streamflow and water-quality data collected at USGS site 07144780 are available at U.S. Geological Survey (2020). Streamflow and waterquality data are used for concentration, load, and yield model computations. These models are useful for quantification and characterization of water-quality constituents of interest and allow for comparison with water-quality criteria and computation of loads and yields to quantify constituent transport in the drainage basin.

\section{Purpose and Scope}

The purpose of this report is to update previously published (Christensen and others, 2006; Stone and others, 2013a) regression models that establish relations between continuous and discrete water-quality data and to assess and quantify water-quality concentrations, loads, and trends during 1999 through 2019 at the inflow site (fig. 1) for the following waterquality constituents of interest: TSS, suspended-sediment concentration (SSC), TP, nitrate, nitrate plus nitrite, and total organic carbon (TOC). These constituents were selected for their relation to water-supply and water-quality issues in the reservoir including reservoir storage, nutrient transport, drinking-water treatment, taste-and-odor events, and harmful algal blooms. The Cheney Reservoir inflow long-term dataset (U.S. Geological Survey, 2020) presented a unique opportunity for long-term data analyses. Water-quality monitoring is essential to assess effects of conservation efforts, measure nutrient load changes, maintain modeled relations, and deliver data to the public in real time. The water-quality information presented in this report is important to the City of Wichita because it quantifies and characterizes potential pollutants, including nutrients and sediment, transported into Cheney Reservoir. In addition, the methods and results used in this study contribute to understanding the effects of agricultural land-use practices on surface-water resources and could be applied to other sites regionally, nationally, and globally.

\section{Description of Study Area and Background Information}

The Cheney Reservoir drainage basin, in south-central Kansas (fig. 1), has a contributing drainage area of $933 \mathrm{mi}^{2}$. The North Fork Ninnescah River is the largest tributary into Cheney Reservoir and contributes about 70 percent of the inflow (Christensen and others, 2006). The inflow site streamgage (USGS site 07144780) has a drainage area of $744 \mathrm{mi}^{2}$. Land use in the Cheney Reservoir drainage basin is predominantly rural; less than 1 percent of the land use in the drainage basin is classified as urban (fig. 1). Drainage basin land use primarily consists of about 51 percent cropland, 26 percent grassland, and about 18 percent CRP land (Peterson and others, 2010).

The reservoir basin is underlain by consolidated rocks of Permian age that are covered by unconsolidated fluvial and eolian deposits of the Pleistocene age (Zeller, 1968). Topographically, the basin is typified by a land surface that is flat to gently sloping (Stone and others, 2015). Soils in the basin are mostly fine sandy loam and loamy fine sand (Rockers and others, 1966; Horsch and others, 1968; Dodge and others, 1978).

The closest daily Global Historical Climatology Network $(\mathrm{GHCN})$ station with a precipitation and temperature record during the analysis period is Hutchinson $10 \mathrm{SW}$ (GHCN station GHCND:USC00143930; Menne and others, 2012b). The GHCN station is 5.6 miles north of the inflow site. The historical mean annual temperature (1959-2019) at the Hutchinson GHCN station was 55.79 degrees Fahrenheit $\left({ }^{\circ} \mathrm{F}\right)$ and was about the same for the analysis period during 1999-2019 (55.77 ${ }^{\circ} \mathrm{F}$; Menne and others, 2012a). Historical mean annual precipitation during 1954 through 2019 at the Hutchinson GHCN station was 29.16 inches (in.) and averaged 30.14 in. for the analysis period during 1999 through 2019. Annual precipitation during the analysis period ranged from 17.79 (2011) to 39.78 in. (2018) (fig. 2).

Extreme precipitation events over a short period of time can cause flooding and increased runoff of nutrients and sediment. Extreme events can have many definitions, making it difficult to directly compare different studies of extreme precipitation events (Barlow and others, 2019). Extreme precipitation can be defined as the top 1 percent of daily station precipitation observations (Agel and others, 2018, 2019). The top 1 percent of daily station precipitation observations during the period of record (1954-2019) at the Hutchinson GHCN station would be any 24-hour period with precipitation totals greater than or equal to 1.69 in. (hereinafter, "extreme precipitation"). During the analysis period, the annual number of days with extreme precipitation ranged from 0 to 10 days per year with the total annual extreme precipitation ranging from 0 to 20.67 in. (fig. 2). The annual precipitation percentage accumulated during extreme precipitation events ranged from 0 to 56 percent with a mean of 32 percent. In some years, a large 


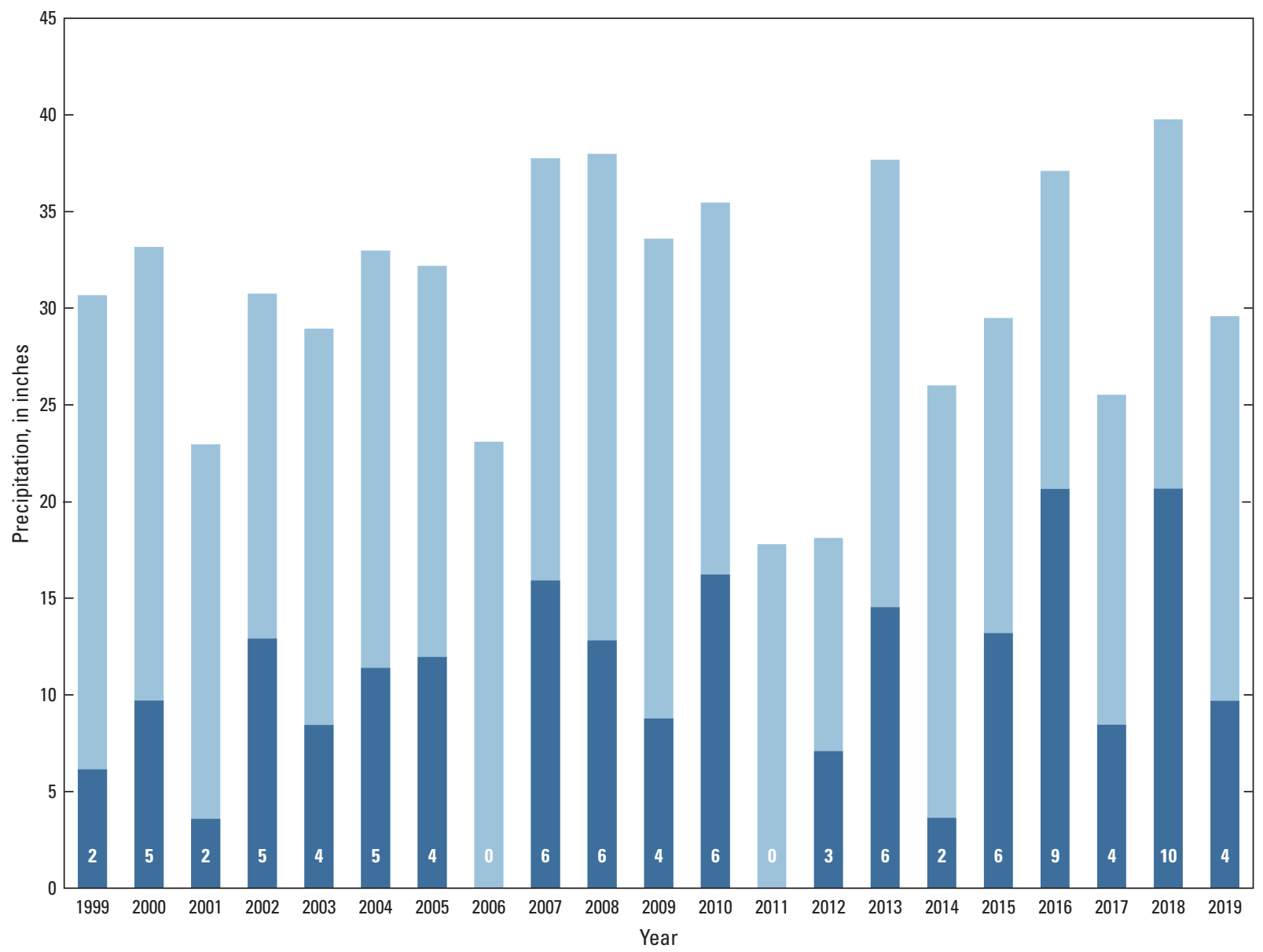

EXPLANATION

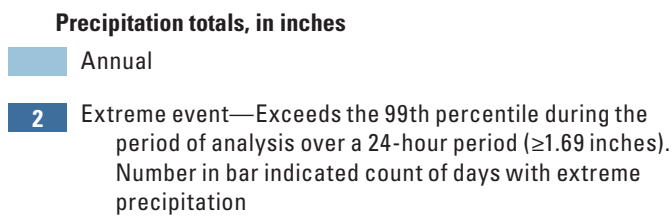

Figure 2. Annual precipitation totals, extreme event precipitation totals, and counts of extreme precipitation days for Global Historical Climatology Network station Hutchinson 10 SW, in Hutchinson, Kansas (GHCND:USC00143930; Menne and others, 2012a; National Oceanic and Atmospheric Administration, 2018).

part of the total annual precipitation occurred during extreme precipitation events when increased runoff of nutrients and sediment was more likely.

Stream ecosystem structure and function are largely affected by streamflow (Allan and Castillo, 2007).

Continuously measured streamflow is important for understanding, measuring, and modeling transport of stream waterquality constituents. Sediment is a primary aquatic impairment in the Nation (U.S. Environmental Protection Agency, 2017), including Kansas (Kansas Department of Health and Environment, 2018). Sediment transport into Cheney Reservoir is a concern because it degrades water quality and progressively decreases water-storage capacity. Cheney Reservoir has been identified as impaired under section 303(d) of the Federal Clean Water Act for siltation (Kansas
Department of Health and Environment, 2018). Suspended sediment in streams decreases light penetration and photosynthesis, smothers benthic habitats, and interferes with feeding activities (Wetzel, 2001). Suspended sediments are usually the result of erosion and subsequent transport of land-surface soils and channel banks. Suspended particulates also promote sorption of nutrients, organic compounds, and other potential contaminants such as bacteria.

Nutrients, primarily nitrogen and phosphorus, are leading causes of water-quality degradation in Kansas and the Nation (U.S. Environmental Protection Agency, 2000, 2016a, b; Kansas Department of Health and Environment, 2004; Dubrovsky and others, 2010). Nutrients are necessary for plant and animal growth, but excessive nutrients can lead to adverse human-health and ecological effects. Excess nutrients can lead 
to eutrophication, harmful algal blooms, low dissolved-oxygen concentrations, taste-and-odor issues, increased turbidity, fish kills, and depletion of flora and fauna (Wetzel, 2001). Point sources of nutrients include municipal and industrial wastewater effluent and storm sewer discharge; nonpoint sources include livestock, crop fertilizers, and urban runoff. Nutrients in the Cheney Reservoir drainage basin generally originate from nonpoint sources and are likely related to agriculture (Christensen and Pope, 1997). Cheney Reservoir is listed as an impaired waterbody under section 303(d) of the Federal Clean Water Act for eutrophication, resulting from excess total nitrogen and TP (Kansas Department of Health and Environment, 2015b).

Nitrogen is present as ammonia, nitrate, nitrite, and part of organic compounds. Most algae use dissolved forms of inorganic nitrogen (Hem, 1985); of those, nitrate is the form of nitrogen most easily used by plants and algae and is the most common ion in many oxygen-rich waters because the nitrite ion is more unstable than nitrate and is easily oxidized to nitrate. Large nitrate concentrations (greater than 10 milligrams per liter $[\mathrm{mg} / \mathrm{L}]$ as nitrogen) in drinking water can cause adverse health effects for humans, such as methemoglobinemia, a condition also known as "blue baby syndrome" (Walton, 1951). This condition restricts the oxygen-carrying capacity of the blood in infants and may be fatal (Walton, 1951; Camargo and Alonso, 2006; U.S. Environmental Protection Agency, 2009). Consumption of nitrate and nitrite in drinking water also has been implicated in other humanhealth problems, including specific cancers and reproductive problems; however, more research is needed to confirm associations (Ward and others, 2005; Dubrovsky and others, 2010).

\section{Related Water-Quality Studies}

Since 1996, the USGS, in cooperation with the City of Wichita, has completed studies in the Cheney Reservoir drainage basin to measure and describe water-quality conditions. Occasional taste-and-odor events have occurred at Cheney Reservoir since the onset of sampling efforts in 2001 (Graham and others, 2017). Initial studies determined subbasin sources of contaminants, chemical loading into and out of Cheney Reservoir, changes in reservoir sediment quality over time, and drainage basin sources of phosphorus (for example, Christensen and Pope, 1997; Pope and Milligan, 2000; Pope and others, 2002). Later studies focused on real-time computations of water-quality constituent concentrations and mass transport from the drainage basin and the description of reservoir conditions that may result in the occurrence of cyanobacteria and associated compounds (for example, Christensen and others, 2006; Stone and others, 2013a, b; Graham and others, 2017). These studies have assisted in development, implementation, maintenance, and assessment of drainage-basinmanagement goals and plans to maintain Cheney Reservoir as a public-water supply and recreational resource. Key findings from these studies include the following:
1. Phosphorus transport from the drainage basin has been increasing over time. Median concentrations of natural TP were 166 milligrams per kilogram in 8-in. soil cores from 43 sites in the drainage basin. Agricultural activities, likely related to fertilizer application, within the drainage basin have increased TP concentrations in soil to about three times natural concentrations, and agricultural activities have accounted for about 65 percent of the phosphorus transported to Cheney Reservoir. Estimates of mean TP concentrations in two of five sampled streams in the drainage basin do not meet the long-term CRTF water-quality goal $(0.10 \mathrm{mg} / \mathrm{L})$ under natural conditions (Pope, 1998; Mau, 2001; Pope and others, 2002).

2. At the North Fork Ninnescah River, the long-term goal for TSS $(100 \mathrm{mg} / \mathrm{L})$ was not exceeded, the long-term goal for nitrate $(1.2 \mathrm{mg} / \mathrm{L})$ was occasionally exceeded, and the long-term goal for phosphorus $(0.10 \mathrm{mg} / \mathrm{L})$ was commonly exceeded during 1999 through 2012. Base-flow goals for these constituents were commonly exceeded at the North Fork Ninnescah River and other streams in the Cheney Reservoir drainage basin (Pope and others, 2002; Christensen and others, 2006; Stone and others, 2013a).

3. Sediment accumulation in Cheney Reservoir was less than expected. As of 2001, only 4 percent of the original storage capacity of Cheney Reservoir was lost because of sedimentation (Mau, 2001). A substantial amount of the sediment load delivered to Cheney Reservoir occurs during short periods. A total of 41 percent of the sediment load transported to Cheney Reservoir during 1966 through 2013 was delivered during eight 24-hour periods (Stone and others, 2015).

4. Cyanobacteria, rather than actinomycetes bacteria, are the likely producers of the taste-and-odor compounds geosmin and 2-methylisoborneol (MIB) in Cheney Reservoir. Anabaena sp. was identified as the likely producer of Geosmin and an unresolved member of the order Oscillatoriales is the likely producer of MIB. Geosmin is common in Cheney Reservoir whereas MIB is less common (Christensen and others, 2006; Stone and others, 2013b; Otten and others, 2016).

5. There are broad seasonal patterns in cyanobacteria and associated compound occurrences in Cheney Reservoir; however, event timing and magnitude vary among years. There is generally a small winter peak in cyanobacteria associated with geosmin and a larger summer peak associated with the cyanotoxin microcystin. Microcystis sp. was identified as the likely producer of microcystin. Large inflow events to the reservoir may disrupt typical seasonal patterns (Otten and others, 2016; Graham and others, 2017). 
Other similar studies have used a statistical approach based on weighted regressions to study changes in flownormalized annual concentrations and fluxes in water-quality constituents in rivers, streams, and tributaries in drainage basins across the Nation (Hirsch and others, 2010; Medalie and others, 2012; Moyer and others; 2012; Murphy and others, 2013; Hirsch and De Cicco, 2015; Hickman and Hirsch, 2017). Exploration and Graphics for RivEr Trends (EGRET), an $\mathrm{R}$ package that processes and shows water-quality trend information (available at https://www.usgs.gov/software/ exploration-and-graphics-river-trends-egret; Hirsch and De Cicco, 2015), contains a Weighted Regressions on Time, Discharge, and Season (WRTDS) module for analysis of long-term flow-normalized water-quality concentrations and flux trends removing year-to-year variation because of time, streamflow, and season. In addition to flow normalization, the WRTDS module also allows for the trend results to be analyzed in smaller periods of time to determine if there are different trends during subsets of the analysis period. Medalie and others (2012) and Murphy and others (2013) were able to identify reversals or reduction in magnitude of trends for TP, total nitrogen, and nitrate during different times of the analysis period other than just an overall trend.

A large study evaluated nearly 12,000 trends in concentration, load, and ecology metrics for water quality including sites near Cheney Reservoir and the North Fork Ninnescah River (Oelsner and others, 2017). Trends in the Little Arkansas River (not shown) and Arkansas River indicated primarily upward trends in nutrients (nitrate, orthophosphate [OP], and TP) during analysis periods 1992-2012 and 2002-12. TSS and SSC in the Little Arkansas River indicted primarily downward trends during 2002-12. Most sites in the State of Kansas analyzed as part of this study also indicated upward trends in nutrients from 2002 to 2012, although there were mixed trends in TSS (Oelsner and others, 2017). Interpretation of the trend results, such as causal analysis, were not included in the scope of the report.

\section{Methods}

Continuous and discrete water-quality data were collected at the inflow site during November 1998 through 2019 over a range of streamflow conditions (U.S. Geological Survey, 2020). These data were used to update existing and develop new linear regression models, compute constituent loads and yields, and identify and examine trends during 1999 through 2019.

\section{Continuous Water-Quality Monitoring}

Continuous (1-hour maximum interval) water-quality and streamflow data were collected at the inflow site (fig. 1). Daily mean values were computed using an aggregated time-weighted average approach. Streamflow was measured since July 1965 using standard USGS methods (Sauer and Turnipseed, 2010; Turnipseed and Sauer, 2010; Painter and Loving, 2015). Continuous water-quality data were collected at the inflow site during November 1998 through 2019. Monitors were installed near the centroid of the stream cross section to best represent conditions across the width of the stream and were maintained using standard USGS procedures (Wagner and others, 2006; Bennett and others, 2014; Rasmussen and others, 2014; Wilde, variously dated). Continuous streamflow and water-quality data are available from the USGS National Water Information System database at https://doi.org/10.5066/F7P55KJN (U.S. Geological Survey, 2020).

Advancements and changes in sensor technology led to changes in deployed water-quality sensors during the analysis period. During November 1998 through November 2015, the inflow site was equipped with a YSI 6600 Extended Deployment System (EDS) water-quality monitor that measured water temperature, specific conductance (an indirect measure of dissolved solids in water [Hem, 1985]), $\mathrm{pH}$, dissolved oxygen (YSI Clark cell or optical dissolvedoxygen sensors), and turbidity (YSI model 6026 or 6136 optical turbidity sensors) (YSI Incorporated, 2007, 2012a). The YSI Clark cell dissolved-oxygen sensor was deployed November 1998 through March 2008. The YSI optical dissolved-oxygen sensor was used March 2008 through November 2015.

Turbidity is a measure of the optical properties of water that decrease the passage of light, and it is caused by suspended and dissolved material such as clay, silt, finely divided organic material, plankton and other microscopic organisms, organic acids, and dyes (ASTM International, 2003; Anderson, 2005). Different turbidity sensors can provide different readings because of differences in the optical properties of the individual sensors (Rasmussen and others, 2009). The YSI model 6026 turbidity sensor was deployed November 1998 through November 2010. The YSI model 6136 turbidity sensor was deployed October 2009 through November 2015. There was a period of side-by-side turbidity data collection between the YSI model 6026 and model 6136 sensors from October 2009 through November 2010. Stone and others (2013a) document comparison data between the YSI model 6026 and model 6136 sensors. In addition to documenting differences in sensor readings, Stone and others (2013a) applied a conversion factor developed using the side-by-side comparison data to the YSI model 6026 dataset. That approach was not used in this report, and each dataset was considered and analyzed independently.

A Xylem YSI EXO water-quality monitor replaced the YSI 6600 EDS water-quality monitor in November 2015 and measured the same properties (YSI Incorporated, 2019). No comparison data were collected between the YSI 6600 EDS water-quality monitor and the YSI EXO water-quality monitor when the replacement occurred in 2015; therefore, a YSI 6600 EDS water-quality monitor was briefly redeployed during April through June in 2017 to collect comparison data at the 
inflow site. The range of streamflow and side-by-side turbidity values collected was not adequate to describe differences in sensor performance at the inflow site. Side-by-side data collection between the YSI 6600 and the YSI EXO monitors was completed as part of a different study at a nearby site and indicated YSI EXO turbidity sensor measurements were about 6 percent smaller than the YSI 6136 turbidity sensor measurements (Stone and others, 2019). Additionally, the manufacturer of the sensors also reported there can be a slight discontinuity in field readings taken with different sensors and readings can vary by as much as 10 percent at the site when transitioning, and EXO readings generally are lower in value (YSI Incorporated, 2012b). No conversion or correction was applied to the YSI EXO turbidity data to relate them to the previous sensors, and the dataset was considered and analyzed as reported. As equipment was upgraded to new sensors, the newest sensor was considered the primary dataset in the continuous record even if the data overlapped with the previous sensor.

\section{Discrete Water-Quality Sampling}

Discrete water-quality samples used for model development and calibration were collected over a range of streamflow conditions from January 1999 through September 2017 using primarily depth- and width-integrated sample collection techniques (U.S. Geological Survey, 2006). Discrete waterquality samples collected during 2018-19 were not included for model development because of time constraints related to laboratory reporting. During ice, extreme cold, or extreme low-flow conditions, samples ( 32 percent of total samples collected) were collected using single vertical, multiple vertical, or grab sample methods (U.S. Geological Survey, 2006). Samples collected using single vertical, multiple vertical, or grab sample collection techniques were reviewed and compared to cross-section water-quality field readings measured during the sample and other samples collected during similar conditions to determine if the sample and approach were representative of the mean chemical composition of the stream cross-sectional area. If a sample was determined to not be representative of the cross section, it was excluded from the dataset (detailed in appendixes 1 through 18). Discrete water-quality data are available from the USGS National Water Information System database at https://doi.org/10.5066/ F7P55KJN (U.S. Geological Survey, 2020).

Samples were analyzed for TSS and SSC, nutrients (nitrate plus nitrite, nitrate, OP, and TP), and TOC. TSS, nutrients, and TOC were analyzed by the Wichita Municipal Water and Wastewater Laboratory (WMWWL) in Wichita, Kans., according to standard methods (American Public Health Association and others, 1995). Selected nutrient and replicate samples were sent to the USGS National Water Quality Laboratory (NWQL) in Lakewood, Colorado, and analyzed according to methods presented in Fishman and Friedman
(1989). SSC was analyzed at the USGS Iowa Sediment Laboratory in Iowa City, Iowa, using methods described in Guy (1969).

TSS and SSC are two analytes typically used to describe concentrations of suspended solid-phase material in surface water, and although the terms are sometimes used interchangeably, the laboratory analytical methods differ; as such, the measured concentrations differ as well, particularly when samples contain sand-sized material (Gray and others, 2000). TSS represents solid suspended materials, which may consist of organic or inorganic materials. These materials can come from a variety of sources including algae, decaying vegetation, agricultural and urban runoff, municipal and industrial discharges, and physical degradation of geologic formations. TSS is reported as the measurement of the dry weight of the organic and inorganic solids filtered from a subsample of the original sample. SSC is the measure of the dry weight of the organic and inorganic sediment in a full sample volume of a water-sediment mixture (Guy, 1969). Suspended sediment may consist of clay, silt, sand, or organic material. SSCs were included in the analysis because they are generally considered to be more reliable than TSS for quantifying solids in natural water (Gray and others, 2000).

\section{Quality Assurance and Quality Control}

Continuously measured water-quality data are routinely reviewed and approved according to standard USGS methods (Wagner and others, 2006; Bennett and others, 2014; Rasmussen and others, 2014; Wilde, variously dated). Water temperature, specific conductance, $\mathrm{pH}$, and dissolved-oxygen sensor maxima were not exceeded during the analysis period. Individual turbidity sensors vary in maximum readings. The operational limit for the YSI model 6026 and YSI model 6136 turbidity sensors of 1,000 formazin nephelometric units (FNU) was exceeded 0.2 and 0.002 percent of the time, respectively, and exceedances were retained in the dataset. The Xylem YSI EXO turbidity sensor never exceeded the maximum operational limit of 4,000 FNU during the analysis period.

Time-series measurements occasionally were missing or deleted from the dataset because of equipment malfunction, excessive fouling caused by environmental conditions, extreme low- or no-flow conditions, or temporary removal of equipment because of ice. During January 1999 through December 2019, about 9 percent of the hourly streamflow record, 8 percent of the water temperature record, 2.2 percent of the specific conductance record, 9 percent of the $\mathrm{pH}$ record, 12 percent of the dissolved-oxygen record, 8 percent of the YSI model 6026 turbidity record, 25 percent of the YSI model 6136 turbidity record, and 14 percent of the Xylem YSI EXO turbidity record were missing or deleted from NWIS (table 2), largely because of low-flow or icy conditions and occasionally because of sensor fouling (Wagner and others, 2006; Bennett and others, 2014; U.S. Geological Survey, 2020). 
Quality-control (QC) samples routinely were collected to identify, quantify, and document bias and variability in data that resulted from collecting, processing, and analyzing samples (U.S. Geological Survey, 2006). QC samples included replicate, blank, and standard reference samples for discretely collected water-quality samples. Relative percentage difference (RPD) was used to evaluate analyte concentration differences between replicates. The RPD was calculated by dividing the absolute difference between replicate pairs by the mean and multiplying that value by 100 . RPDs were not calculated for replicate pairs that had consistent nondetections (both values in the replicate pair were censored) or inconsistent detections (one value in the replicate pair was a detected value and the other value was censored; Mueller and others, 2015).

About 10 percent of discrete water-quality samples collected during 1999-2017 were QC samples. Sequential, split, and concurrent replicate water-quality samples were collected during the analysis period over a range of streamflow conditions. Replicate comparisons included 18 TSS pairs (comparing WMWWL analysis pairs); 11 SSC pairs (comparing USGS Iowa Sediment Laboratory analysis pairs); 40 nitrate plus nitrite, nitrate, OP, and TP pairs (comparing $18 \mathrm{WMWWL}$ and $22 \mathrm{WMWWL} / \mathrm{NWQL}$ analysis pairs); and 17 TOC pairs (comparing $11 \mathrm{WMWWL}$ and $6 \mathrm{WMWWL/NWQL}$ analysis pairs) (tables 3, 4, and 5). TP and TOC included sequential replicates that were analyzed by the WMWWL and NWQL for laboratory comparison. Replicate pairs with an RPD within 10 percent were considered acceptable for TSS and SSC. Replicate pairs with an RPD within 20 percent were considered acceptable for nutrients and TOC. Replicate pair RPDs were not calculated for pairs that had consistent nondetections or inconsistent detections. OP had 3 consistent nondetections and 4 inconsistent detection replicate pairs. Median TSS and SSC replicate RPDs were less than or equal to 10 percent ( 7 and 10 percent, respectively). Median replicate RPDs were less than 20 percent for nutrients and TOC: median nitrate plus nitrite and nitrate RPDs were 4 percent, median OP RPD was 19 percent, and median TOC RPD was 6 percent.

Blank samples were collected to measure the magnitude of contaminant concentration that may have been introduced to samples because of sampling, processing, or analytical procedures (U.S. Geological Survey, 2006). Blank samples consisted of deionized water, inorganic blank water, or organic blank water, depending on the analysis. During 1999 through 2017, 12 blank samples were collected and analyzed for TSS, nitrate plus nitrite, nitrate, OP, and TOC. TSS, nitrate plus nitrite, and nitrate were not detected in blank samples. OP and

Table 2. Summary statistics for variables measured continuously at the North Fork Ninnescah River upstream from Cheney Reservoir (U.S. Geological Survey site 07144780), south-central Kansas, January 1, 1999, through December 31, 2019.

[Continuous real-time water-quality data are available on the U.S. Geological Survey National Real-Time Water Quality website (https://nrtwq.usgs.gov/ks); $n$, number of measurements; $\mathrm{ft} 3 / \mathrm{s}$, cubic foot per second; $\mu \mathrm{S} / \mathrm{cm}$, microsiemens per centimeter at 25 degrees Celsius; FNU, formazin nephelometric unit; <, less than; ${ }^{\circ} \mathrm{C}$, degree Celsius; $\mathrm{mg} / \mathrm{L}$, milligram per liter]

\begin{tabular}{|c|c|c|c|c|c|c|}
\hline Continuous variable & $n$ & Minimum & Maximum & Mean & Median & $\begin{array}{c}\text { Percent } \\
\text { missing } \\
\text { data }\end{array}$ \\
\hline \multicolumn{7}{|c|}{ Daily mean measurements } \\
\hline Streamflow (ft3/s) 1965-2019 & 19,907 & 0 & 9,140 & 135 & 76 & 0 \\
\hline Streamflow $\left(\mathrm{ft}^{3} / \mathrm{s}\right)$ 1999-2019 & 7,670 & 0 & 8,250 & 128 & 77 & 0 \\
\hline Specific conductance $(\mu \mathrm{S} / \mathrm{cm})$ & 6,883 & 167 & 1,840 & 1,160 & 1,190 & 10 \\
\hline Turbidity (26136, FNU) & 3,146 & $<1.0$ & 396 & 23 & 15 & 16 \\
\hline \multicolumn{7}{|c|}{ Hourly measurements } \\
\hline Streamflow & 260,098 & 0.0 & 9,630 & 133 & 75 & 9 \\
\hline Water temperature $\left({ }^{\circ} \mathrm{C}\right)$ & 193,377 & -0.2 & 39.8 & 15.3 & 15.3 & 8 \\
\hline Turbidity $(16026$, FNU) & 96,483 & $<1.0$ & 1,700 & 45.8 & 27 & 8 \\
\hline Turbidity (26136, FNU) & 43,838 & $<1.0$ & 1,160 & 23.7 & 16 & 25 \\
\hline Turbidity $\left(\mathrm{EXO}^{3}, \mathrm{FNU}\right)$ & 38,633 & 3.2 & 750 & 22.1 & 13 & 14 \\
\hline
\end{tabular}

${ }^{1}$ YSI model 6026 turbidity sensor installed November 9, 1998, through October 16, 2009.

2YSI model 6136 turbidity sensor installed October 17, 2009, through November 12, 2015.

3YSI Xylem EXO turbidity sensor installed November 13, 2015, through December 31, 2019. 
Table 3. Summary of quality-control replicate results for all discretely collected replicate data, 1999 through 2017.

[QC, quality control; ISL, Iowa Sediment Laboratory; mg/L, milligram per liter; USGS, U.S. Geological Survey; pcode, parameter code; RPD, relative percentage difference; <, less than]

\begin{tabular}{|c|c|c|c|c|c|c|c|}
\hline \multirow[b]{2}{*}{ OC summary statistics } & \multicolumn{6}{|c|}{ All replicate pairs } & \multirow[b]{2}{*}{$\begin{array}{c}\text { ISL } \\
\text { Suspended-sediment } \\
\text { concentration, } \\
\text { mg/L } \\
\text { (USGS } \\
\text { pcode 80154) }\end{array}$} \\
\hline & $\begin{array}{l}\text { Total suspended } \\
\text { solids, water, } \\
\text { unfiltered, mg/L } \\
\text { (USGS } \\
\text { pcode 00530) }\end{array}$ & $\begin{array}{l}\text { Nitrate plus nitrite, } \\
\text { water, filtered, } \\
\text { mg/L as nitrogen } \\
\text { (USGS } \\
\text { pcode 00631) }\end{array}$ & $\begin{array}{c}\text { Nitrate, } \\
\text { water, filtered, } \\
\text { mg/L as nitrogen } \\
\text { (USGS } \\
\text { pcode 00618) }\end{array}$ & $\begin{array}{l}\text { Orthophosphate, } \\
\text { water, filtered, } \\
\text { mg/L as phosphorus } \\
\text { (USGS } \\
\text { pcode 00671) }\end{array}$ & $\begin{array}{c}\text { Phosphorus, } \\
\text { water, unfiltered, } \\
\text { mg/L as phosphorus } \\
\text { (USGS } \\
\text { pcode 00665) }\end{array}$ & $\begin{array}{l}\text { Organic carbon, } \\
\text { water, unfiltered, } \\
\text { mg/L } \\
\text { (USGS } \\
\text { pcode 00680) }\end{array}$ & \\
\hline Total number of replicate pairs & 18 & 40 & 40 & 40 & 40 & 17 & 11 \\
\hline $\begin{array}{l}\text { Number of inconsistent nondetect } \\
\text { replicate pairs }{ }^{1}\end{array}$ & 0 & 0 & 0 & 4 & 0 & 0 & 0 \\
\hline $\begin{array}{l}\text { Number of consistent nondetect } \\
\text { replicate pairs }{ }^{1}\end{array}$ & 0 & 0 & 0 & 3 & 0 & 0 & 0 \\
\hline $\begin{array}{l}\text { Number of replicate pairs used } \\
\text { for RPD statistics }\end{array}$ & 18 & 40 & 40 & 33 & 40 & 17 & 11 \\
\hline Minimum RPD & $<1.0$ & 0 & 0 & 0 & 0 & $<1.0$ & 0 \\
\hline Maximum RPD & 47 & 182 & 117 & 153 & 32 & 95 & 116 \\
\hline Mean RPD & 11 & 14 & 9 & 28 & 11 & 13 & 20 \\
\hline Median RPD & 7 & 4 & 4 & 19 & 9 & 6 & 10 \\
\hline
\end{tabular}

${ }^{1}$ Inconsistent and consistent nondetect replicate pairs were not used for RPD statistics. 
Table 4. Summary of quality-control replicate results for Wichita Municipal Water and Wastewater Laboratory discretely collected replicate data, 1999 through 2017.

[QC, quality control; WMWWL, Wichita Municipal Water and Wastewater Laboratory; mg/L, milligram per liter; USGS, U.S. Geological Survey; pcode, parameter code; RPD, relative percentage difference; $<$, less than]

\begin{tabular}{|c|c|c|c|c|c|c|}
\hline \multirow[b]{2}{*}{ QC summary statistics } & \multicolumn{6}{|c|}{ WMWWL replicate analysis } \\
\hline & $\begin{array}{l}\text { Total suspended solids, } \\
\text { water, unfiltered, } \\
\text { mg/L } \\
\text { (USGS } \\
\text { pcode 00530) }\end{array}$ & $\begin{array}{l}\text { Nitrate plus nitrite, } \\
\text { water, filtered, } \\
\text { mg/L as nitrogen } \\
\text { (USGS } \\
\text { pcode 00631) }\end{array}$ & $\begin{array}{c}\text { Nitrate, } \\
\text { water, filtered, } \\
\text { mg/L as nitrogen } \\
\text { (USGS } \\
\text { pcode 00618) }\end{array}$ & $\begin{array}{c}\text { Orthophosphate, } \\
\text { water, filtered, } \\
\text { mg/L as phosphorus } \\
\text { (USGS } \\
\text { pcode 00671) }\end{array}$ & $\begin{array}{c}\text { Phosphorus, } \\
\text { water, unfiltered, } \\
\text { mg/L as phosphorus } \\
\text { (USGS } \\
\text { pcode 00665) }\end{array}$ & $\begin{array}{c}\text { Organic carbon, } \\
\text { water, unfiltered, } \\
\text { mg/L } \\
\text { (USGS } \\
\text { pcode 00680) }\end{array}$ \\
\hline Total number of replicate pairs & 18 & 18 & 18 & 18 & 18 & 11 \\
\hline $\begin{array}{l}\text { Number of inconsistent nondetect } \\
\text { replicate pairs }{ }^{1}\end{array}$ & 0 & 0 & 0 & 0 & 0 & 0 \\
\hline $\begin{array}{l}\text { Number of consistent nondetect } \\
\text { replicate pairs }{ }^{1}\end{array}$ & 0 & 0 & 0 & 3 & 0 & 0 \\
\hline $\begin{array}{l}\text { Number of replicate pairs used for } \\
\text { RPD statistics }\end{array}$ & 18 & 18 & 18 & 15 & 18 & 11 \\
\hline Minimum RPD & $<1.0$ & 0 & 0 & 0 & 0 & $<1.0$ \\
\hline Maximum RPD & 47 & 5 & 6 & 153 & 32 & 11 \\
\hline Mean RPD & 11 & 1 & 1 & 27 & 10 & 4 \\
\hline Median RPD & 7 & 0 & 1 & 15 & 10 & 3 \\
\hline
\end{tabular}

${ }^{1}$ Inconsistent and consistent nondetect replicate pairs were not used for RPD statistics. 
Table 5. Summary of quality-control replicate results for discretely collected data comparing Wichita Municipal Water and Wastewater Laboratory and National Water Quality Laboratory results, 1999 through 2017.

[QC, quality control; WMWWL, Wichita Municipal Water and Wastewater Laboratory; NWQL, National Water Quality Laboratory; mg/L, milligram per liter; USGS, U.S. Geological Survey; pcode, parameter code; RPD, relative percentage difference; $<$, less than]

\begin{tabular}{|c|c|c|c|c|c|}
\hline \multirow[b]{2}{*}{ OC summary statistics } & \multicolumn{5}{|c|}{ WMWWL/NWOL replicate comparison } \\
\hline & $\begin{array}{l}\text { Nitrate plus nitrite, } \\
\text { water, filtered, } \\
\text { mg/L as nitrogen } \\
\text { (USGS } \\
\text { pcode 00631) }\end{array}$ & $\begin{array}{c}\text { Nitrate, } \\
\text { water, filtered, } \\
\text { mg/L as nitrogen } \\
\text { (USGS } \\
\text { pcode 00618) }\end{array}$ & $\begin{array}{c}\text { Orthophosphate, } \\
\text { water, filtered, } \\
\text { mg/L as phosphorus } \\
\text { (USGS } \\
\text { pcode 00671) }\end{array}$ & $\begin{array}{c}\text { Phosphorus, } \\
\text { water, unfiltered, } \\
\text { mg/L as phosphorus } \\
\text { (USGS } \\
\text { pcode 00665) }\end{array}$ & $\begin{array}{c}\text { Organic carbon, } \\
\text { water, unfiltered, } \\
\text { mg/L } \\
\text { (USGS } \\
\text { pcode 00680) }\end{array}$ \\
\hline Total number of replicate pairs & 22 & 22 & 22 & 22 & 6 \\
\hline Number of inconsistent nondetect replicate pairs ${ }^{1}$ & 0 & 0 & 4 & 0 & 0 \\
\hline Number of consistent nondetect replicate pairs 1 & 0 & 0 & 0 & 0 & 0 \\
\hline Number of replicate pairs used for RPD statistics & 22 & 22 & 18 & 22 & 6 \\
\hline Minimum RPD & 0 & 0 & 0 & 0 & $<1.0$ \\
\hline Maximum RPD & 182 & 117 & 102 & 30 & 95 \\
\hline Mean RPD & 25 & 15 & 28 & 11 & 30 \\
\hline Median RPD & 12 & 7 & 22 & 8 & 21 \\
\hline
\end{tabular}

IInconsistent and consistent nondetect replicate pairs were not used for RPD statistics. 
TP were detected in one sample and TOC was detected in four samples; all detections were at or near the analytical detection limit.

Standard reference samples were analyzed by the WMWWL and submitted to the USGS Branch of Quality Systems at least annually and oftentimes biannually (10 out of 15 years since beginning in 2003) for laboratory-performance evaluation. RPDs between the WMWWL value and the Branch of Quality Systems most probable value were computed. Reported values usually were within 10 percent of the most probable value during the analysis period. Median RPDs for the analysis period for TSS, nitrate plus nitrite, nitrate, OP, and TP were 7, 6, 5, 4, and 5 percent, respectively. Median percentage differences between WMWWL results and most probable values indicated that laboratory data generally were consistent and unbiased.

\section{Development of Regression Models to Compute Constituent Concentrations}

Stepwise regression analysis was done using $\mathrm{R}$ programming language (R Core Team, 2019) to relate discretely measured constituent concentrations to concomitant continuously measured water-quality physical properties (Rasmussen and others, 2005; Rasmussen and others, 2008; Rasmussen and others, 2009; Helsel and others, 2020). Discrete samples used for the model calibration dataset were collected during 1999 through 2017. Concomitant continuously measured water-quality values were time interpolated to the time of the discretely collected water-quality sample. If concomitant continuous data were not available ( 2 or more hours of values bracketing the sample collection time were missing) because of fouling, changes in equipment, or unsuitable site conditions, the secondary monitor (field monitor) value measured during sampling was substituted. If no continuous water-quality data were available, the sample was not included in the model calibration dataset.

Linear regression models were developed for TSS, SSC, nitrate plus nitrite, nitrate, OP, TP, and TOC using R version 3.5.3 (R Core Team, 2019). The ordinary least squares estimation method was used to fit linear models for constituents without censored data (results less than the minimum reporting laboratory value; TSS, SSC, TOC) (Rasmussen and others, 2009). Tobit regression methods were used for fitting linear models for constituents that had one or more censored results in the model calibration dataset using the absolute maximum likelihood estimation approach (nitrate plus nitrite, nitrate, OP, TP) (Hald, 1949; Cohen, 1950; Tobin, 1958; Helsel and others, 2020). Untransformed and logarithm base $10\left(\log _{10}\right)$ transformations were used for continuously measured water-quality constituents and discrete sample concentrations.

Each model was evaluated using methods for development and quantification of uncertainty as described in Rasmussen and others (2009), Stone and others (2013b), and
Helsel and others (2020). Explanatory variables were evaluated individually and in combination and included streamflow, water temperature, specific conductance, $\mathrm{pH}$, dissolved oxygen, and turbidity. Seasonal components (sine and cosine variables) were also evaluated as explanatory variables to identify potential cyclical patterns because of seasonality. For each modeled constituent, a streamflow-only based model was developed to compute concentrations and loads during periods when concomitant water-quality physical parameters were unavailable. The streamflow-based models do not perform as well as their water-quality-based model counterparts and were only developed and used to compute a complete historical dataset.

Separate models were developed for different turbidity sensors (YSI model 6026 and YSI model 6136) because of previously described differences in sensor readings. No models were developed using YSI EXO turbidity sensor data because of inadequate sample size for model calibration. Discrete sample data collected during the deployment of the YSI EXO turbidity sensor were not included in the model calibration datasets for turbidity-based models described in this report.

Regression model equations and periods of application for each individual model are detailed in table 6. Details and model diagnostics of regression models developed in this study and previously published model equations are presented in appendixes 1 through 18 . Models described in this report supersede all prior models used during the analysis period.

\section{Calculation of Annual Constituent Loads and Yields and Streamflow-Separation Point}

Daily concentrations of TSS, SSC, nitrate plus nitrite, nitrate, OP, TP, and TOC were computed using the newly developed regression models and water-quality or streamflow daily mean values for the period January 1, 1999, through December 31, 2019. Daily mean values were used to compute concentrations and loads for the analysis period because of missing instantaneous streamflow data and periods of missing water-quality data. If 15-minute or hourly streamflow data were missing within a 24-hour period, daily mean values were estimated, reviewed, and approved following Turnipseed and Sauer (2010) and Painter and Loving (2015). For continuous water-quality data, including 24-hour periods missing less than 25 percent of data because of extreme weather, waterquality monitor malfunction, or routine maintenance visits, daily mean values were computed using an aggregated timeweighted average and were reviewed and approved according to USGS methods (U.S. Geological Survey, 2006; Wagner and others, 2006; Bennett and others, 2014; Wilde, variously dated). If more than 25 percent of continuous water-quality data are missing or if daily maximum or minimum values were not accurately represented, a daily mean value was not computed. 
Table 6. Updated and new regression models and summary statistics for continuous concentration computations for the North Fork Ninnescah River upstream from Cheney Reservoir (U.S. Geological Survey site 07144780), south-central Kansas, model validation period 1999 through 2017.

$\left[R^{2}\right.$, coefficient of determination; RMSE, root mean square error; RSE, residual standard error; $n$, number of discrete samples; $\%$, percent; log, logarithm base 10 ; TBY 6026 , turbidity from YSI sensor 6026 , in formazin nephelometric units; sin, sine; $D$, decimal day of year; cos, cosine; App., Appendix; --, no data or not calculated; TBY 6136 , turbidity from YSI sensor 6136, in formazin nephelometric units; Q, streamflow in cubic feet per second; <, less than; SPC, specific conductance in microsiemens per centimeter at 25 degrees Celsius]
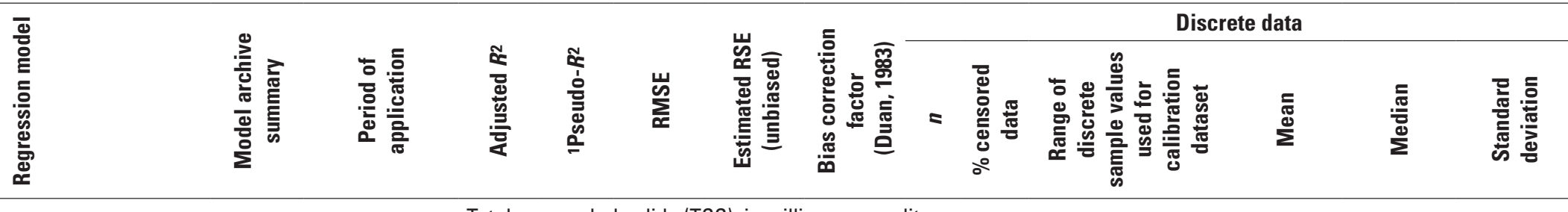

\begin{tabular}{|c|c|c|c|c|c|c|c|c|c|c|c|c|c|}
\hline \multicolumn{14}{|c|}{ Total suspended solids (TSS), in milligrams per liter } \\
\hline $\begin{array}{l}\log (T S S)=0.806 \log \left(T B Y_{6026}\right) \\
+0.135 \sin (2 \pi D)-0.0463 \cos (2 \pi D)+0.408\end{array}$ & App. 1 & $\begin{array}{l}1 / 1 / 1999 \\
10 / 16 / 2009\end{array}$ & 0.89 & -- & 0.1530 & 0.1551 & 1.06 & 77 & 0 & $\begin{array}{l}\text { TSS: } 8.4-696 \\
\text { TBY }_{6026}: 12.4-960\end{array}$ & $\begin{array}{l}155 \\
144\end{array}$ & $\begin{array}{l}120 \\
110\end{array}$ & $\begin{array}{l}140 \\
159\end{array}$ \\
\hline $\log (T S S)=0.964 \log \left(T B Y_{6136}\right)+0.26$ & App. 2 & $\begin{array}{r}10 / 17 / 2009 \\
12 / 31 / 2019\end{array}$ & 0.84 & -- & 0.1750 & 0.1750 & 1.08 & 30 & 0 & $\begin{array}{l}\text { TSS: } 10-381 \\
\text { TBY }_{6136}: 6.5-230\end{array}$ & $\begin{array}{r}120 \\
72\end{array}$ & $\begin{array}{l}91 \\
66\end{array}$ & $\begin{array}{l}97 \\
54\end{array}$ \\
\hline $\log (T S S)=0.464 \log (Q)+0.877$ & App. 3 & $\begin{array}{l}21 / 1 / 1999 \\
12 / 31 / 2019\end{array}$ & 0.44 & -- & 0.3430 & 0.3430 & 1.35 & 101 & 0 & $\begin{array}{l}\text { TSS: } 8.4-696 \\
\text { Q: } 5.29-8,220\end{array}$ & $\begin{array}{l}143 \\
643\end{array}$ & $\begin{array}{l}112 \\
205\end{array}$ & $\begin{array}{r}130 \\
1,220\end{array}$ \\
\hline \multicolumn{14}{|c|}{ Suspended-sediment concentration (SSC), in milligrams per liter } \\
\hline $\begin{array}{l}\log (S S C)=0.471 \log (Q)+0.626 \log \left(T B Y_{6026}\right) \\
\quad-0.0555\end{array}$ & App. 4 & $\begin{array}{l}1 / 1 / 1999- \\
10 / 16 / 2009\end{array}$ & 0.88 & -- & 0.2060 & 0.2075 & 1.12 & 69 & 0 & $\begin{array}{l}\text { SSC: } 15-2,690 \\
\text { Q: } 14.2-8,220 \\
\text { TBY }_{6026}: 12.4-960\end{array}$ & $\begin{array}{l}452 \\
799 \\
143\end{array}$ & $\begin{array}{l}208 \\
255 \\
113\end{array}$ & $\begin{array}{r}586 \\
1,410 \\
152\end{array}$ \\
\hline $\log (S S C)=1.13 \log \left(T B Y_{6136}\right)+0.365$ & App. 5 & $\begin{array}{r}10 / 17 / 2009 \\
12 / 31 / 2019\end{array}$ & 0.73 & -- & 0.2820 & 0.2820 & 1.21 & 30 & 0 & $\begin{array}{l}\text { SSC: } 10-2,390 \\
\text { TBY }_{6136}: 6.5-230\end{array}$ & $\begin{array}{r}361 \\
72\end{array}$ & $\begin{array}{r}216 \\
66\end{array}$ & $\begin{array}{r}442 \\
54\end{array}$ \\
\hline $\log (S S C)=0.752 \log (Q)+0.488$ & App. 6 & $\begin{array}{l}\text { 21/1/1999- } \\
12 / 31 / 2019\end{array}$ & 0.70 & -- & 0.3140 & 0.3140 & 1.29 & 94 & 0 & $\begin{array}{l}\text { SSC: } 10-2,690 \\
\text { Q: } 5.29-8,220\end{array}$ & $\begin{array}{l}393 \\
677\end{array}$ & $\begin{array}{l}208 \\
214\end{array}$ & $\begin{array}{r}520 \\
1,260\end{array}$ \\
\hline \multicolumn{14}{|c|}{ Nitrate plus nitrite $\left(\mathrm{NO}_{3} \mathrm{NO}_{2}\right)$, in milligrams per liter as nitrogen } \\
\hline $\begin{array}{l}\mathrm{NO}_{3} \mathrm{NO}_{2}=0.000399(S P C)+0.0224 \sin (2 \pi D) \\
\quad+0.563 \cos (2 \pi D)+0.533\end{array}$ & App. 7 & $\begin{array}{r}1 / 1 / 1999 \\
12 / 31 / 2019\end{array}$ & -- & 0.60 & -- & 0.3099 & -- & 123 & 1.6 & $\begin{array}{l}\mathrm{NO}_{3} \mathrm{NO}_{2}:<0.01-2.38 \\
\text { SPC: } 156-1,462\end{array}$ & $\begin{array}{l}0.66 \\
889\end{array}$ & $\begin{array}{l}0.52 \\
974\end{array}$ & $\begin{array}{l}0.48 \\
360\end{array}$ \\
\hline $\begin{array}{l}\mathrm{NO}_{3} \mathrm{NO}_{2}=-0.216 \log (Q)+0.0996 \sin (2 \pi D) \\
\quad+0.600 \cos (2 \pi D)+1.39\end{array}$ & App. 8 & $\begin{array}{l}21 / 1 / 1999 \\
12 / 31 / 2019\end{array}$ & -- & 0.59 & -- & 0.3090 & -- & 109 & 0.9 & $\begin{array}{l}\mathrm{NO}_{3} \mathrm{NO}_{2}:<0.01-2.38 \\
\text { Q: } 5.3-8,217\end{array}$ & $\begin{array}{l}0.67 \\
608\end{array}$ & $\begin{array}{l}0.53 \\
181\end{array}$ & $\begin{array}{l}0.47 \\
1,190\end{array}$ \\
\hline \multicolumn{14}{|c|}{ Nitrate $\left(\mathrm{NO}_{3}\right)$, in milligrams per liter as nitrogen } \\
\hline $\begin{array}{l}\mathrm{NO}_{3}=0.00037(S P C)+0.0265 \sin (2 \pi D) \\
\quad+0.538 \cos (2 \pi D)+0.532\end{array}$ & App. 9 & $\begin{array}{r}1 / 1 / 1999 \\
12 / 31 / 2019\end{array}$ & -- & 0.58 & -- & 0.2947 & -- & 109 & 0.9 & $\begin{array}{l}\mathrm{NO}_{3}:<0.01-2.38 \\
\text { SPC: } 156-1,433\end{array}$ & $\begin{array}{l}0.63 \\
849\end{array}$ & $\begin{array}{l}0.50 \\
897\end{array}$ & $\begin{array}{l}0.45 \\
348\end{array}$ \\
\hline
\end{tabular}


Table 6. Updated and new regression models and summary statistics for continuous concentration computations for the North Fork Ninnescah River upstream from Cheney Reservoir (U.S. Geological Survey site 07144780), south-central Kansas, model validation period 1999 through 2017._-Continued

$\left[R^{2}\right.$, coefficient of determination; RMSE, root mean square error; RSE, residual standard error; $n$, number of discrete samples; $\%$, percent; log, logarithm base 10 ; TBY 6026 , turbidity from YSI sensor 6026 , in formazin nephelometric units; sin, sine; $D$, decimal day of year; cos, cosine; App., Appendix; --, no data or not calculated; TBY 6136 , turbidity from YSI sensor 6136, in formazin nephelometric units; Q, streamflow in cubic feet per second; <, less than; SPC, specific conductance in microsiemens per centimeter at 25 degrees Celsius]
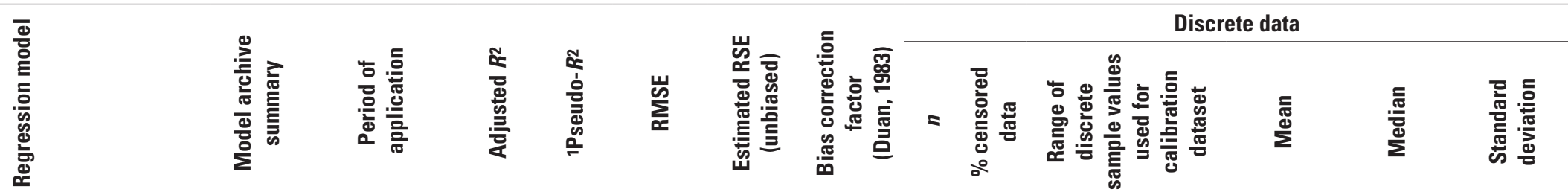

Nitrate $\left(\mathrm{NO}_{3}\right)$, in milligrams per liter as nitrogen-Continued

\begin{tabular}{|c|c|c|c|c|c|c|c|c|c|c|c|c|c|}
\hline $\begin{array}{l}\mathrm{NO}_{3}=-0.1987 \log (Q)+0.0929 \sin (2 \pi D) \\
\quad+0.604 \cos (2 \pi D)+1.34\end{array}$ & App. 10 & $\begin{array}{l}21 / 1 / 1999- \\
12 / 31 / 2019\end{array}$ & -- & 0.59 & -- & 0.2990 & -- & 100 & 1 & $\begin{array}{l}\mathrm{NO}_{3}:<0.01-2.38 \\
\mathrm{Q}: 5.3-8,217\end{array}$ & $\begin{array}{l}0.65 \\
648\end{array}$ & $\begin{array}{l}0.52 \\
214\end{array}$ & $\begin{array}{l}0.46 \\
1,240\end{array}$ \\
\hline \multicolumn{14}{|c|}{ Orthophosphate (OP), in milligrams per liter as phosphorus } \\
\hline $\log (O P)=-0.00144(S P C)-0.196$ & App. 11 & $\begin{array}{l}1 / 1 / 1999 \\
12 / 31 / 2019\end{array}$ & -- & 0.68 & -- & 0.3457 & 1.33 & 108 & 32.4 & $\begin{array}{l}\text { OP: }<0.01-0.23 \\
\text { SC: } 156-1,433\end{array}$ & $\begin{array}{l}0.06 \\
846\end{array}$ & $\begin{array}{l}0.05 \\
897\end{array}$ & $\begin{array}{l}0.09 \\
348\end{array}$ \\
\hline $\log (O P)=0.804 \log (Q)-3.346$ & App. 12 & $\begin{array}{l}21 / 1 / 1999 \\
12 / 31 / 2019\end{array}$ & -- & 0.70 & -- & 0.3488 & 1.32 & 99 & 34.3 & $\begin{array}{l}\text { OP: }<0.01-0.23 \\
\text { Q: } 5.3-8,217\end{array}$ & $\begin{array}{l}0.05 \\
654\end{array}$ & $\begin{array}{c}0.04 \\
223\end{array}$ & $\begin{array}{l}0.09 \\
1,240\end{array}$ \\
\hline \multicolumn{14}{|c|}{ Total phosphorus (TP), in milligrams per liter as phosphorus } \\
\hline $\log (T P)=0.524 \log \left(T B Y_{6026}\right)-1.705$ & App. 13 & $\begin{array}{l}1 / 1 / 1999- \\
10 / 16 / 2009\end{array}$ & -- & 0.60 & -- & 0.2052 & 1.09 & 94 & 1.1 & $\begin{array}{l}\text { TP: }<0.03-0.73 \\
\text { TBY }_{6026}: 12.4-1,386\end{array}$ & $\begin{array}{l}0.27 \\
164\end{array}$ & $\begin{array}{l}0.26 \\
114\end{array}$ & $\begin{array}{l}0.16 \\
199\end{array}$ \\
\hline $\log (T P)=0.717 \log \left(T B Y_{6136}\right)-1.938$ & App. 14 & $\begin{array}{r}10 / 17 / 2009 \\
12 / 31 / 2019\end{array}$ & -- & 0.76 & -- & 0.1682 & 1.07 & 30 & 3.3 & $\begin{array}{l}\text { TP: }<0.03-0.57 \\
\text { TBY }_{6136}: 6.5-230\end{array}$ & $\begin{array}{l}0.24 \\
72\end{array}$ & $\begin{array}{l}0.24 \\
66\end{array}$ & $\begin{array}{l}0.14 \\
55\end{array}$ \\
\hline $\log (T P)=0.327 \log (Q)-0.147$ & App. 15 & $\begin{array}{l}\text { 21/1/1999- } \\
12 / 31 / 2019\end{array}$ & -- & 0.39 & -- & 0.2593 & 1.17 & 118 & 1.7 & $\begin{array}{l}\text { TP: }<0.03-0.73 \\
\text { Q: } 5.3-8,217\end{array}$ & $\begin{array}{l}0.26 \\
674\end{array}$ & $\begin{array}{l}0.26 \\
249\end{array}$ & $\begin{array}{l}0.16 \\
1,180\end{array}$ \\
\hline \multicolumn{14}{|c|}{ Total organic carbon (TOC), in milligrams per liter } \\
\hline $\log (T O C)=0.421 \log \left(T B Y_{6026}\right)+0.138$ & App. 16 & $\begin{array}{l}1 / 1 / 1999- \\
10 / 16 / 2009\end{array}$ & 0.65 & -- & 0.1490 & 0.1490 & 1.05 & 60 & 0 & $\begin{array}{l}\text { TOC: } 2.50-22.5 \\
\text { TBY }_{6026}: 12.4-960\end{array}$ & $\begin{array}{r}11 \\
168\end{array}$ & $\begin{array}{r}11 \\
120\end{array}$ & $\begin{array}{r}5 \\
170\end{array}$ \\
\hline $\log (T O C)=0.381 \log \left(T B Y_{6136}\right)+0.296$ & App. 17 & $\begin{array}{r}10 / 17 / 2009 \\
12 / 31 / 2019\end{array}$ & 0.48 & -- & 0.1590 & 0.1590 & 1.06 & 30 & 0 & $\begin{array}{l}\text { TOC: } 2.30-18.1 \\
\text { TBY }_{6136}: 6.5-230\end{array}$ & $\begin{array}{l}10 \\
72\end{array}$ & $\begin{array}{l}10 \\
66\end{array}$ & $\begin{array}{r}4 \\
54\end{array}$ \\
\hline $\log (T O C)=0.257 \log (Q)+0.331$ & App. 18 & $\begin{array}{l}21 / 1 / 1999- \\
12 / 31 / 2019\end{array}$ & 0.47 & -- & 0.1780 & 0.1780 & 1.08 & 84 & 0 & $\begin{array}{l}\text { TOC: } 2.30-22.5 \\
\text { Q: } 5.29-8,220\end{array}$ & $\begin{array}{r}10 \\
742\end{array}$ & $\begin{array}{r}10 \\
241\end{array}$ & $\begin{array}{r}5 \\
1,320\end{array}$ \\
\hline
\end{tabular}

1Pseudo- $R^{2}$ is computed using the McKelvey-Zavoina (1975) method. For uncensored data, it is equal to the $R^{2}$ value for ordinary least squares.

2Flow-based models (Q) are considered secondary models and were only used when primary model data (continuous water-quality data) were missing for concentration and load computation. 
Constituent concentrations were computed using a combination of developed models. The streamflow-based regression models were used to compute constituent concentrations when continuous water-quality data were unavailable because daily mean streamflow values are available for the entire analysis period. The streamflow-based computed constituent concentrations were shifted to align with the primary waterquality surrogate-regression model-computed values directly preceding and following the streamflow-based computed concentrations, similar to methods described in Porterfield (1972), to better align computed concentration differences among model types.

The load (also referred to as the flux; the term flux is used in this report when referencing WRTDS output because that term is the output term from the WRTDS package) of a riverborne constituent is the amount (mass) that passes a given point on the river over a given period. The yield of a riverborne constituent is the flux per unit drainage area. Constituent loads, in tons per day, were calculated from January 1, 1999, through December 31, 2019, by multiplying computed daily concentrations (in milligrams per liter) by daily streamflow (in cubic feet per second) and a unit conversion factor (0.0027 to calculate the load in tons per day). Annual loads, in tons, were calculated by summing the daily loads. Annual yields (in pounds per square mile) were calculated by dividing the annual loads (converted to pounds) by the contributing drainage area at the inflow site $\left(744 \mathrm{mi}^{2}\right)$.

Additional YSI EXO turbidity sensor specific models were not developed for constituents that used turbidity as an explanatory variable (TSS, SSC, TP, and TOC) because of inadequate sample size. In the absence of this YSI EXO turbidity-specific model, the YSI EXO turbidity daily values were used for computations with the model developed using the YSI model 6136 turbidity data. YSI EXO turbidity sensors can be lower in value compared to YSI model 6136 sensors (YSI Incorporated, 2012b; Stone and others, 2019), and it is likely that constituent concentration and load computations using YSI EXO turbidity data (November 2015 through December 2019) could be biased low.

A streamflow-separation point was defined for base-flow and runoff constituent concentrations for comparing waterquality conditions and CRTF goals for TSS, nitrate, and TP (table 1). A 10-percent streamflow-separation point, determined by the discharge duration curve for the analysis period (fig. $3 A$ ), was used to define base-flow and runoff conditions using methods described in Stone and others (2013a) that followed KDHE's TMDL curve methodology for characterizing flood conditions (Kansas Department of Health and Environment, [undated]). Duration curves are cumulative distribution functions and were constructed using hourly streamflow values to evaluate frequency and magnitude characteristics. Duration curves indicate either the percentage of time that specified conditions were equaled or exceeded or the frequency of exceedance (Maidment, 1993). The Weibull formula (Helsel and others, 2020) was used for calculating plotting position. Streamflow and water-quality constituent duration curves for the inflow site are available for the period of record on the USGS National Real-Time Water Quality website https://nrtwq.usgs.gov/ks/. Water-quality criteria exceedances were determined using duration curves. Because of uncertainty associated with quantifying criteria exceedances based on duration curves, the exceedances in this report should be considered as approximations.

\section{Identification of Constituent Trends}

Trends in TSS, SSC, nitrate plus nitrite, OP, TP, and TOC water-quality data were analyzed using EGRET, an R package that processes and shows water-quality trend information (Hirsch and De Cicco, 2015). Nitrite only contributed a small percentage (2.4 percent on average) to nitrate plus nitrite concentrations in discrete samples. Because the nitrate plus nitrite dataset was more robust than the nitrate dataset and contributions from nitrite were minimal, only the nitrate plus nitrite dataset was used for EGRET analysis. The EGRET package contains a WRTDS module for analysis of long-term, flownormalized water-quality concentration and flux computations and trends (Hirsch and others, 2010; Hirsch and De Cicco, 2015). In this report, WRTDS models also include the use of the WRTDS bootstrap test (WBT; Hirsch and others, 2015).

Benefits of WRTDS analysis include detecting temporal trends that may not conform to linear forms and suitability for use with irregularly spaced data. WRTDS analysis does not assume the discharge/concentration relation is uniform, the concentration residuals are homoscedastic, or that seasonal patterns remain the same throughout the period of analysis. Flow-normalization computation is another benefit of WRTDS because it removes the effect of streamflow on the loads and allows the user to evaluate the effect of management actions on the trends of constituents of interest.

To provide a method for a common description of trends to accompany statements of statistical significance, including confidence intervals, Hirsch and others (2015) developed a set of definitions for descriptive statements partly based on terminology and language used by the Intergovernmental Panel on Climate Change (Mastrandrea and Mach, 2011). This allows for a set of likelihood statements that can be treated as a continuum ranging from a strong indication that there is a trend (highly likely) to a conclusion that the likelihood of a trend is virtually equal to the opposite trend (highly unlikely). Thus, this approach may be more suitable to the types of decisions that need to be made with respect to water quality (Hirsch and others, 2015).

The WBT within the Exploration and Graphics for RivEr Trends Confidence Intervals (EGRETci) R package was used on WRTDS analysis results to quantify the uncertainty in the direction and likelihood of trends. For this report, concentrations, flow-normalized concentrations, fluxes, and flownormalized fluxes were computed annually, and changes in annual flow-normalized concentrations and fluxes between selected years were computed for the analysis period (1999 

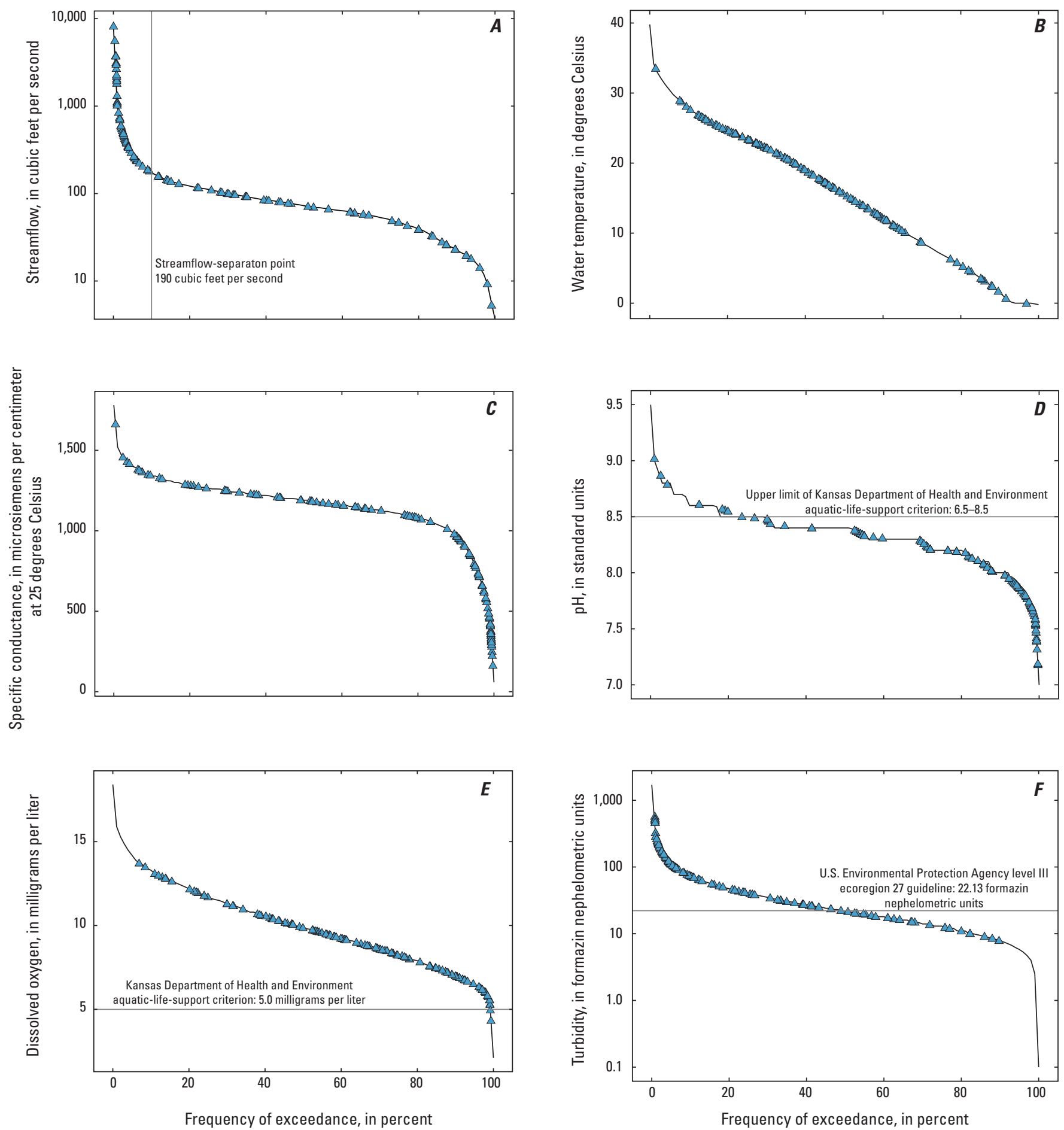

\section{EXPLANATION}

Duration curve of continuously monitored data

$\triangle \quad$ Discrete measurements

Figure 3. Duration curves for hourly and discretely measured constituents at the North Fork Ninnescah River upstream from Cheney Reservoir (U.S. Geological Survey site 07144780), south-central Kansas, 1999 through 2019. $A$, streamflow; $B$, water temperature; $C$, specific conductance; $D, \mathrm{pH} ; E$, dissolved oxygen; $F$, turbidity (multiple turbidity sensor data combined). 
through 2019). The analysis period was divided equally into two periods in addition to the full analysis period (1999-2009, 2009-19, and 1999-2019) to better examine trend changes for concentration and flux for each of the modeled constituents. The final analysis step in this method was determining if changes in flow-normalized concentrations and fluxes constituted a trend. Because discrete samples used in this analysis are only available through 2017, the WBT analysis was not able to extrapolate trends and trend magnitudes beyond the conclusion of the model calibration dataset. Indepth interpretation of the trend results, such as causal analysis, are outside the scope of this report.

\section{Regression Relations and Water-Quality Trend Results}

Annual differences in streamflow in the Cheney Reservoir drainage basin can be attributed to precipitation (Stone and others, 2013a). At the inflow site, continuous streamflow ranged from 0 to 9,630 cubic feet per second ( $\left.\mathrm{ft}^{3} / \mathrm{s}\right)$ during 1999 through 2019 and daily mean streamflow ranged from 0 to $8,250 \mathrm{ft}^{3} / \mathrm{s}$ (table 2). There was a period of 8 days in July and August 2012 when there was no streamflow because of drought conditions. Daily mean streamflow for the analysis period was $128 \mathrm{ft}^{3} / \mathrm{s}$, which was about $7 \mathrm{ft}^{3} / \mathrm{s}$ less than the daily mean streamflow for the period of record (July 1965-December 2019; table 2) and $1 \mathrm{ft} 3 / \mathrm{s}$ less than mean streamflow during 1999-2012 as reported in Stone and others (2013a). The 10-percent streamflow-separation point, determined by the discharge duration curve, was used to differentiate between base-flow and runoff conditions and occurred at $190 \mathrm{ft}^{3} / \mathrm{s}$ (fig. $3 A$ ), which was $18 \mathrm{ft}^{3} / \mathrm{s}$ less than the streamflowseparation point calculated for 1999-2012 in Stone and others (2013a).

\section{Continuously Monitored Water-Quality Variables}

Continuously measured water temperature ranged from -0.2 to 39.8 degrees Celsius $\left({ }^{\circ} \mathrm{C}\right)$, which was the range previously reported, and had a mean of $15.3^{\circ} \mathrm{C}$ (table 2, fig. $3 B$; Stone and others, 2013a). Continuously measured specific conductance ranged from 58 to 1,870 microsiemens per centimeter $(\mu \mathrm{S} / \mathrm{cm})$ at 25 degrees Celsius and had a mean value of $1,160 \mu \mathrm{S} / \mathrm{cm}$ during 1999 through 2019 (table 2, fig. 3C), which exceeded the maximum $(1,760 \mu \mathrm{S} / \mathrm{cm})$ and mean $(1,144 \mu \mathrm{S} /$ $\mathrm{cm}$ ) values previously reported for the period 1999-2012 (Stone and others, 2013a). The specific conductance daily values in the 95th percentile and larger (greater than $1,380 \mu \mathrm{S} / \mathrm{cm}$ ) are typically seen during low-flow conditions (mean of $81 \mathrm{ft} 3 / \mathrm{s}$ ) and are likely the results of groundwater seepage with fairly high dissolved concentrations affected by the Salt Plain Formation and the Ninnescah Shale (not shown) that underlies the southcentral part of the study area (Gillespie and Hargadine, 1994).

The $\mathrm{pH}$ value is a measure of the effective hydrogen ion concentration and is often used to evaluate aquatic chemical and biological reactions (Stumm and Morgan, 1996). Kansas aquatic-life-support criteria require that $\mathrm{pH}$ values in streams not measure less than 6.5 or more than 8.5 standard units (Kansas Department of Health and Environment, 2015a). Continuously measured $\mathrm{pH}$ ranged from 7 to 9.5 and had a median of 8.4 during the analysis period (table 2). Measured $\mathrm{pH}$ was never lower than 6.5 but exceeded 8.5 about 28 percent of the time during 1999 through 2019 (fig. 3D). Exceedances primarily occurred during low-flow conditions during spring and summer months and likely were caused by increased algal photosynthesis in the stream (Graham and others, 2010). Exceedances of $\mathrm{pH}$ occurred about 19 percent of the time during 1999 through 2012 (Stone and others, 2013a).

Continuously measured dissolved-oxygen concentrations ranged from 2.1 to $18.4 \mathrm{mg} / \mathrm{L}$ during 1999 through 2019, as previously reported in Stone and others (2013a), and had a mean of $10.0 \mathrm{mg} / \mathrm{L}$ during the analysis period (table 2). Kansas aquaticlife-support criteria require that dissolved-oxygen concentrations are not less than $5.0 \mathrm{mg} / \mathrm{L}$ (Kansas Department of Health and Environment, 2015a). Dissolved-oxygen concentrations were less than the minimum aquatic-life-support criterion less than 1 percent of the time during 1999 through 2019 (fig. 3E). Dissolved-oxygen concentrations of less than $5 \mathrm{mg} / \mathrm{L}$ occurred during May through October and generally during periods of increased water temperatures (greater than $20^{\circ} \mathrm{C}$ ) and seasonal low flows. Dissolved oxygen is an important factor for the survival of aquatic organisms, and concentrations in surface water are related primarily to photosynthesis, respiration, atmospheric reaeration, and water temperature (Wilde, 2008).

Continuously measured turbidity (YSI model 6026) during January 1999 through October 2009 ranged from less than 1.0 to $1,700 \mathrm{FNU}$ and had a mean of $45.8 \mathrm{FNU}$; turbidity (YSI model 6136) during October 2009 through November 2015 ranged from less than 1.0 to $1,160 \mathrm{FNU}$ and had a mean of 23.7 FNU; and turbidity (YSI Xylem EXO) during November 2015 through December 2019 ranged from 3.2 to $750 \mathrm{FNU}$ and had a mean of 22.1 FNU (table 2). As discussed previously, sensor technology differences can cause a discontinuity in field readings taken with the different sensors with each new sensor generally being lower in value to its predecessor. The U.S. Environmental Protection Agency (EPA) guidelines for turbidity (based on reference conditions) list 22.13 FNU for level III ecoregion 27 (Central Great Plains) streams, which includes the North Fork Ninnescah River (U.S. Environmental Protection Agency, 2001). Guidelines are nonenforceable goals developed for the protection of water quality, aquatic life, and human health. Continuously measured turbidity exceeded the EPA guideline of $22.13 \mathrm{FNU}$ about 48 percent of the time during 1999 through 2019; exceedances occurred across a range of streamflows (fig. $3 F$ ). 


\section{Regression Models for Selected Constituents}

Previously published linear regression models by Christensen and others (2006) and Stone and others (2013a) for TSS, SSC, nitrate plus nitrite, nitrate, OP, TP, and TOC were updated or developed using discrete sample data collected from 1999 through 2017. Summary statistics of data used for the development of these models and their application periods are provided in table 7, and model archive summaries, including previous model versions, are provided in appendixes 1-18. Updated and new regression models are provided in table 6.

TSS, SSC, TP, and TOC models include turbidity as an explanatory variable, and concentrations and loads for these constituents were continuously computed using daily mean turbidity values when they were available ( 88 percent of analysis period; table 6 ). When turbidity daily mean values were unavailable, the streamflow-based models (table 6) were used for concentration and load computations. Additionally, because a YSI EXO turbidity-specific model was not developed, the YSI EXO turbidity daily values were used in the YSI model 6136 turbidity calibrated model computations. This approach could bias computations low for the EXO deployment period (November 2015 through December 2019).

Nitrate plus nitrite, nitrate, and OP models include specific conductance as an explanatory variable, and concentrations and loads for these constituents were continuously computed using daily mean specific conductance values when they were available (90 percent of analysis period; table 6). When specific conductance daily mean values were unavailable, streamflow-based models (table 6) were used for concentration and load computations.

There are limitations to comparing computed concentrations and loads in this report to previously published computations (Christensen and others, 2006; Stone and others, 2013a). The previously developed models had unique model calibration datasets (turbidity data conversion factors, and so on) and had varying levels of uncertainty. Additionally, Stone and others (2013a) computed concentrations using continuous water-quality data whereas this report uses daily mean values because of limitations from missing continuous data. Using daily mean values smooths some of the inherent variability that is detected in the denser continuous datasets. Comparisons to previously published concentrations and loads are included in this report, but variance should be expected and considered accordingly.

\section{Total Suspended Solids and Suspended-Sediment Concentration}

The range of discretely sampled TSS concentrations was 8.4 to $696 \mathrm{mg} / \mathrm{L}$ and was similar to previously published ranges (table 7; Christensen and others, 2006; Stone and others, 2013a). Turbidity was an explanatory variable for TSS in both previously published models and the updated models; the updated models explained 89 percent and 84 percent of the variance for the YSI 6026 and YSI 6136 turbidity sensor models, respectively (table 6; appendixes 1-2). The updated YSI 6026 turbidity sensor model also included seasonality as an explanatory variable likely because of seasonal patterns in agricultural land-use practices, precipitation, and subsequent runoff. The updated streamflow-based TSS model explained 44 percent of the variance in TSS concentrations (appendix 3), which was about 40-45 percent less variance than the turbidity-based models for the YSI 6026 and YSI 6136 turbidity sensors, respectively (table 6), and 15-19 percent less variance than the previously published streamflow-based models. The large decrease in variance explained from previously published streamflow-based models is likely due to the larger range of streamflow values in the new model calibration dataset.

Turbidity was used as a surrogate for SSC in previously published and updated models. The range of discretely sampled SSC was 10 to $2,690 \mathrm{mg} / \mathrm{L}$ and was similar to the range reported for 1999 through 2012 (table 7; Stone and others, 2013a). The updated YSI 6026 turbidity sensor model also included streamflow as an explanatory variable and explained 88 percent of the variance in SSC (table 6; appendix 4). The updated SSC model using YSI 6136 turbidity sensor data explained 73 percent of the variance in SSC (table 6; appendix 5). The updated streamflow-based SSC model explained 3-18 percent less variance than the turbidity-based models (table 6; appendix 6).

Turbidity is a physical property related to TSS and is an indicator of sediment and other solid material transported in streams (Anderson, 2005). Turbidity is often used as a surrogate measure for TSS and SSC and has previously been used as a surrogate for models in this drainage basin (Christensen and others, 2006; Rasmussen and others, 2009; Stone and others, 2013a).

\section{Nutrients and Carbon}

The range of discretely sampled nitrate plus nitrite concentrations was less than 0.01 to $2.38 \mathrm{mg} / \mathrm{L}$ (table 7). Nitrate plus nitrite models were developed using specific conductance and seasonality as explanatory variables along with a streamflow-based model using streamflow and seasonality (table 6; appendixes 7,8). The specific conductance-andseasonality-based model explained 60 percent of the variance and the streamflow-and-seasonality-based model explained 59 percent of the variance in nitrate plus nitrite concentrations (table 6). The range of discretely sampled nitrate concentrations was also less than 0.01 to $2.38 \mathrm{mg} / \mathrm{L}$ and was similar to previously published ranges (table 7; Stone and others, 2013a). The updated nitrate model also includes specific conductance and seasonality as explanatory variables (table 6; appendix 9), whereas the model developed in Stone and others (2013a) used turbidity and seasonality as explanatory variables. The updated specific conductance-and-seasonality-based model explained 58 percent of the variance in nitrate concentrations. 
Table 7. Summary statistics for discretely collected constituents at the North Fork Ninnescah River upstream from Cheney Reservoir (U.S. Geological Survey site 07144780), south-central Kansas, January 1, 1999, through September 30, 2017. Data from U.S. Geological Survey (2020).

[mg/L, milligram per liter; USGS, U.S. Geological Survey; pcode, parameter code; $n$, number of discrete samples; <, less than; \%, percent; --, no data or not calculated]

\begin{tabular}{|c|c|c|c|c|c|c|c|}
\hline Summary statistic & $\begin{array}{l}\text { Total suspended } \\
\text { solids, water, } \\
\text { unfiltered, } \\
\text { mg/L } \\
\text { (USGS } \\
\text { pcode 00530) }\end{array}$ & $\begin{array}{l}\text { Suspended- } \\
\text { sediment } \\
\text { concentration, } \\
\text { mg/L } \\
\text { (USGS } \\
\text { pcode 80154) }\end{array}$ & $\begin{array}{l}\text { Nitrate plus nitrite, } \\
\text { water, filtered, } \\
\text { mg/L as nitrogen } \\
\text { (USGS } \\
\text { pcode 00631) }\end{array}$ & $\begin{array}{l}\text { Nitrate, water, } \\
\text { filtered, } \\
\text { mg/L as nitrogen } \\
\text { (USGS } \\
\text { pcode 00618) }\end{array}$ & $\begin{array}{l}\text { Orthophosphate, } \\
\text { water filtered, } \\
\text { mg/L as phosphorus } \\
\text { (USGS } \\
\text { pcode 00671) }\end{array}$ & $\begin{array}{c}\text { Phosphorus, } \\
\text { water, unfiltered, } \\
\text { mg/L as phosphorus } \\
\text { (USGS } \\
\text { pcode 00665) }\end{array}$ & $\begin{array}{c}\text { Organic } \\
\text { carbon, water, } \\
\text { unfiltered, mg/L } \\
\text { (USGS } \\
\text { pcode 00680) }\end{array}$ \\
\hline$n$ & 108 & 101 & 123 & 109 & 107 & 127 & 91 \\
\hline Minimum & 8.4 & 10 & $<0.01$ & $<0.01$ & $<0.01$ & $<0.03$ & 2.3 \\
\hline Mean1 & 154 & 425 & 0.66 & 0.63 & 0.06 & 0.27 & 11 \\
\hline Median & 113 & 226 & 0.52 & 0.5 & 0.05 & 0.26 & 11 \\
\hline Maximum & 696 & 2,690 & 2.38 & 2.38 & 0.24 & 0.77 & 23 \\
\hline$\%$ censored data & -- & -- & 1.6 & 0.9 & 32 & 1.9 & -- \\
\hline Censored value threshold & -- & -- & $<0.01-<0.02$ & $<0.01$ & $<0.01-<0.04$ & $<0.03$ & -- \\
\hline
\end{tabular}

${ }^{1}$ Statistic calculated using absolute maximum likelihood estimation for constituents with censored data (Helsel and Cohn, 1988; Helsel, 2012) 
The streamflow-and-seasonality-based nitrate model was also updated from Stone and others (2013a), and the updated model explained 59 percent of the variance in nitrate concentrations (table 6; appendix 10). The seasonal component enhances the model likely because stream nitrate concentrations are groundwater affected (Stone and others, 2013a), and nitrate concentrations tend to be higher during lower flow conditions in the fall and winter than during runoff conditions. This could also be partially because of seasonal agricultural practices such as fertilizer application in the spring and fall during planting season.

The range of discretely sampled OP concentrations was less than 0.01 to $0.24 \mathrm{mg} / \mathrm{L}$ and was similar to previously published ranges (table 7; Christensen and others, 2006; Stone and others, 2013a). Specific conductance was the explanatory variable in previously developed OP models (Christensen and others, 2006; Stone and others, 2013a) and the updated OP model for this report (table 6; appendix 11). The updated OP model explained 68 percent of the variance (table 6). A new OP model using streamflow as the only explanatory variable was also developed for this report and explained 70 percent of the variance in OP concentrations (table 6; appendix 12).

The range of discretely sampled TP concentrations was less than 0.03 to $0.77 \mathrm{mg} / \mathrm{L}$ and was larger than previously published ranges (table 7; Christensen and others, 2006; Stone and others, 2013a). Turbidity was an explanatory variable in previously developed TP models (Christensen and others, 2006; Stone and others, 2013a) and the updated TP models, likely because phosphorus is bound to suspended sediment and other particulate material (Wetzel, 2001). The updated YSI 6026 turbidity sensor model explained 60 percent of the variance in TP concentrations (table 6; appendix 13). The YSI 6136 turbidity sensor TP model explained 16 percent more ( 76 percent) of the variance in TP concentrations than the YSI 6026 turbidity sensor model (table 6; appendix 14). The difference in variance is likely due to the YSI 6136 model having a smaller range of values for discrete sample concentrations and turbidity conditions. The updated streamflowbased TP model explained 39 percent of the variance in TP concentrations, which is a decrease of 17 percent from the Stone and others (2013a) model, likely because of the larger range of streamflow and concentrations in the model calibration dataset (table 6; appendix 15).

Turbidity was used as a surrogate for the previously published TOC model at the inflow site (Stone and others, 2013a, b) and the updated model, likely because organic material is a major component of suspended solids (Hem, 1985; Juracek and Rasmussen, 2008). The updated YSI 6026 and YSI 6136 turbidity sensor models explained 65 and 48 percent of the variance in TOC concentrations, respectively (table 6, appendixes 16,17 ). The newly developed streamflow-based TOC model explained 47 percent of the variance in TOC concentrations (table 6, appendix 18).

\section{Computed Constituent Concentrations, Fluxes, and Yields}

Computed daily TSS concentrations ranged from less than 1 to $1,220 \mathrm{mg} / \mathrm{L}$ and had a mean of $49 \mathrm{mg} / \mathrm{L}$ during the analysis period (table 8). The mean TSS concentration for the analysis period (based on computed daily values) was 8 percent smaller than the mean concentration reported in Stone and others (2013a) for the period of 1999-2012 (based on computed hourly values; $54 \mathrm{mg} / \mathrm{L}$ ). Annual mean TSS concentrations were largest during 2001 and smallest in 2012. The smallest annual mean TSS concentration $(20 \mathrm{mg} / \mathrm{L})$ also corresponded to the smallest annual mean streamflow $(43.6 \mathrm{ft} 3 / \mathrm{s})$.

The TSS load during 1999 through 2019 was about 292,000 tons (table 9). The smallest annual load was 1,570 tons in 2011 (less than 1 percent of total load), and the largest annual load was 30,700 tons in 2010 (10 percent of total load; fig. 4B). These loads corresponded to the second smallest annual streamflow and the second largest annual streamflow (41,700 acre-feet [acre-ft] and 150,000 acre-ft), respectively (table 9; fig. 4A). Smallest and largest annual TSS load years were the same as reported in Stone and others (2013a) but were about 8 and 30 percent larger, respectively, and could be partially due to differences in model calibration and data computations. The TSS load computed using models developed for this report during 1999 through 2012 was about 215,000 tons and about 23 percent larger than the load reported for the same period in Stone and others (2013a; 174,031 tons).

SSC ranged from less than 1 to $3,580 \mathrm{mg} / \mathrm{L}$ and had a mean of $100 \mathrm{mg} / \mathrm{L}$ during the analysis period based on computed daily concentrations (table 8). Mean SSC for the analysis period (based on computed daily values) was 14 percent larger than the mean concentration reported in Stone and others (2013a) for the period of 1999-2012 (based on computed hourly values; $88 \mathrm{mg} / \mathrm{L}$ ). Annual mean SSC was largest during 2010 and smallest in 2012.

Suspended-sediment load during 1999 through 2019 totaled about 817,000 tons (table 9). The smallest annual load was 3,690 tons in 2011 (less than 1 percent of total load), and the largest annual load was 101,000 tons in 2010 (12 percent of total load; fig. $4 B$ ). These loads corresponded to the second smallest annual streamflow and the second largest annual streamflow years $(41,700$ acre- $\mathrm{ft}$ and 150,000 acre-ft), respectively (table 9; fig. 4A). Smallest and largest annual suspendedsediment load years were the same as reported in Stone and others (2013a) for the analysis period during 1999-2012 but were about 50 percent larger and 12 percent smaller, respectively, and could be partially due to differences in model calibration and data computations.

Suspended-sediment load computed using models developed for this report during 1999 through 2012 was about 593,000 tons and about 14 percent larger than the load reported for the same period in Stone and others (2013a; 518,321 tons). Suspended-sediment load computed using turbidity- and streamflow-based models developed for this report during 1999 through 2013 was about 631,000 and about 
Table 8. Summary of daily statistics for selected water-quality constituents computed with updated and newly developed regression models and continuously measured physicochemical constituents at the North Fork Ninnescah River upstream from Cheney Reservoir (U.S. Geological Survey site 07144780), south-central Kansas, 1999 through 2019.

[Continuous real-time water-quality data are available on the U.S. Geological Survey National Real-Time Water Quality website (https://nrtwq.usgs.gov/ks); $n$, number of measurements; $\mathrm{mg} / \mathrm{L}$, milligram per liter; <, less than]

\begin{tabular}{|c|c|c|c|c|c|}
\hline Water-quality constituent & $n$ & Minimum & Maximum & Mean & Median \\
\hline Total suspended solids, water, unfiltered (mg/L) & 7,670 & $<1$ & 1,220 & 49 & 32 \\
\hline Suspended-sediment concentration (mg/L) & 7,670 & $<1$ & 3,580 & 100 & 58 \\
\hline Nitrate, water, filtered (mg/L as nitrogen) & 7,670 & 0.06 & 1.73 & 0.97 & 0.96 \\
\hline Orthophosphate, water, filtered (mg/L as phosphorus) & 7,670 & $<0.01$ & 0.49 & 0.02 & 0.02 \\
\hline
\end{tabular}

22 percent smaller than the load reported for the same period in Stone and others (2015) using a streamflow-based model (804,287 tons; about 15 percent of the total load for the period 1966-2013 [5,254,281 tons]). Turbidity model-computed loads are different in part because the turbidity-based model had a better fit (lower predicted residual error sum of squares value) than the streamflow-based model and because the loads were computed based on different time series data (daily versus hourly). This further highlights the importance of continued collection of high-quality continuous water-quality data to appropriately measure and predict water-quality conditions in the drainage basin.

The largest annual streamflow was in 2019 , but corresponding TSS and suspended-sediment loads were substantially smaller than 2010 loads (second largest annual streamflow). Model development data limitations and the use of YSI EXO turbidity data for input into the YSI 6136 turbiditycalibrated model for TSS computations likely affected computed 2019 loads.

Sedimentation is progressively reducing the storage capacity of Cheney Reservoir. Substantial parts of suspendedsediment loads are delivered to Cheney Reservoir during short periods associated with extreme flood events: 41 percent of the sediment load transported to the reservoir during 1966 through 2013 occurred during 8 days (Stone and others, 2015). Similarly, during 1999-2019, 55 percent of the suspendedsediment load was transported during the top 1 percent of loading days (76 days); 22 percent of the total load during 1999-2019 was transported in the top 10 loading days. Successful sediment management efforts necessitate reduction techniques that account for these large load events.

Nitrate plus nitrite and nitrate concentrations during the analysis period ranged from 0.04 to $1.82 \mathrm{mg} / \mathrm{L}$ (mean: $1.00 \mathrm{mg} / \mathrm{L}$ ) and 0.06 to $1.73 \mathrm{mg} / \mathrm{L}$ (mean: $0.97 \mathrm{mg} / \mathrm{L}$ ), respectively, based on computed daily concentrations (table 8 ). The mean nitrate concentration for the analysis period was 10 percent smaller than the mean concentration reported in Stone and others (2013a) for the period of 1999-2012 (1.08 mg/L).
Annual mean nitrate plus nitrite and nitrate concentrations were largest during 2012 and smallest in 2009, corresponding to the largest and smallest mean annual specific conductances, respectively. The Federal maximum contaminant level (MCL) for nitrate in drinking water is $10 \mathrm{mg} / \mathrm{L}$ as nitrogen (U.S. Environmental Protection Agency, 2009). An MCL is the highest permissible level (on an annual basis) of a contaminant in water delivered to public-water system users. The $10 \mathrm{mg} / \mathrm{L}$ MCL was never exceeded during 1999 through 2019 (table 8).

The nitrate plus nitrite load was about 2,180 tons and the nitrate load was about 2,120 tons during 1999 through 2019 (table 9). The smallest annual loads for nitrate plus nitrite and nitrate were during 2012 (52 and 50 tons, respectively), and the largest annual loads for nitrate plus nitrite and nitrate were during 2018 (159 and 154 tons, respectively; table 9; fig. 4C). These loads corresponded to the smallest annual streamflow and the fourth largest annual streamflow (31,600 acre-ft and 126,000 acre-ft), respectively (table 9 ; fig. $4 A$ ). The nitrate load computed using models developed for this report during 1999 through 2012 was about 1,410 tons and about 13 percent smaller than the load reported for the same period in Stone and others (2013a; 1,631 tons).

Nitrate plus nitrite and nitrate annual loads were largest in 2018 despite it having the fourth largest annual streamflow. During October through December 2018, 30 percent of the annual streamflow and about 65 percent of total annual nitrate plus nitrite and nitrate loads occurred. The total streamflow in October through December 2018 was, on average, 7 times larger (range: 2.8-22.5 times larger) than the total streamflow during this period of any other year during the study period. In this region, winter wheat is planted during September through October. During this period, 48 percent of the local winter wheat crop was planted by October 9, 2018, and 91 percent had been planted by November 19, 2018 (U.S. Department of Agriculture, 2018a, b). Fertilizer is generally applied at planting (September-October) and again between December and February following recommended planting practices (Paulsen, 1997). If large precipitation and runoff events occur before 
Table 9. Computed annual loads and yields for selected constituents at the North Fork Ninnescah River upstream from Cheney Reservoir (U.S. Geological Survey site 07144780), south-central Kansas, 1999 through 2019.

[All loads and yields are computed using linear regression models and streamflow data. With the exception of streamflow, loads are expressed in tons and yields are expressed in pounds per square mile. Streamflow is expressed in acre-feet and acre-feet per acre for loads and yields, respectively. Yield is calculated using short tons (U.S. customary unit) and the contributing drainage area in the drainage basin upstream from the location of site 07144780,744 square miles]

\begin{tabular}{|c|c|c|c|c|c|c|c|c|c|c|c|c|c|c|c|c|}
\hline \multirow[t]{2}{*}{ Year } & \multicolumn{2}{|c|}{ Streamflow } & \multicolumn{2}{|c|}{$\begin{array}{c}\text { Total suspended } \\
\text { solids } \\
\end{array}$} & \multicolumn{2}{|c|}{ Suspended sediment } & \multicolumn{2}{|c|}{ Nitrate plus nitrite } & \multicolumn{2}{|c|}{ Nitrate } & \multicolumn{2}{|c|}{ Orthophosphate } & \multicolumn{2}{|c|}{$\begin{array}{c}\text { Total } \\
\text { phosphorus }\end{array}$} & \multicolumn{2}{|c|}{$\begin{array}{c}\text { Total organic } \\
\text { carbon }\end{array}$} \\
\hline & Load & Yield & Load & Yield & Load & Yield & Load & Yield & Load & Yield & Load & Yield & Load & Yield & Load & Yield \\
\hline 1999 & 87,600 & 0.18 & 13,600 & 36,600 & 31,400 & 84,500 & 106 & 285 & 103 & 277 & 5.9 & 16 & 25 & 67 & 1,030 & 2,780 \\
\hline 2000 & 91,300 & 0.19 & 19,200 & 51,600 & 61,500 & 165,000 & 124 & 333 & 121 & 325 & 9.6 & 26 & 32 & 86 & 1,270 & 3,400 \\
\hline 2001 & 97,000 & 0.20 & 21,000 & 56,500 & 46,500 & 125,000 & 116 & 312 & 113 & 304 & 8.7 & 23 & 32 & 86 & 1,320 & 3,540 \\
\hline 2002 & 59,600 & 0.13 & 10,800 & 29,000 & 20,800 & 55,900 & 78 & 209 & 75 & 202 & 4.1 & 11 & 19 & 51 & 760 & 2,040 \\
\hline 2003 & 82,100 & 0.17 & 30,200 & 81,200 & 76,400 & 205,000 & 103 & 276 & 100 & 269 & 7.7 & 21 & 34 & 91 & 1,290 & 3,460 \\
\hline 2004 & 95,500 & 0.20 & 14,400 & 38,700 & 36,900 & 99,100 & 107 & 288 & 104 & 280 & 8.2 & 22 & 26 & 71 & 1,100 & 2,950 \\
\hline 2005 & 110,000 & 0.23 & 14,700 & 39,400 & 43,900 & 118,000 & 115 & 310 & 112 & 302 & 13 & 35 & 29 & 78 & 1,220 & 3,280 \\
\hline 2006 & 41,300 & 0.09 & 2,810 & 7,540 & 3,800 & 10,200 & 61 & 165 & 59 & 159 & 1.1 & 3 & 6.9 & 19 & 326 & 877 \\
\hline 2007 & 120,000 & 0.25 & 19,300 & 51,800 & 64,200 & 173,000 & 114 & 307 & 111 & 298 & 17 & 45 & 34 & 91 & 1,430 & 3,850 \\
\hline 2008 & 113,000 & 0.24 & 14,100 & 37,800 & 37,900 & 102,000 & 131 & 352 & 127 & 342 & 8.7 & 23 & 28 & 75 & 1,210 & 3,260 \\
\hline 2009 & 144,000 & 0.30 & 20,700 & 55,500 & 60,100 & 162,000 & 157 & 422 & 153 & 411 & 13 & 34 & 38 & 102 & 1,670 & 4,480 \\
\hline 2010 & 150,000 & 0.31 & 30,700 & 82,400 & 101,000 & 272,000 & 121 & 325 & 118 & 317 & 32 & 86 & 58 & 156 & 2,090 & 5,610 \\
\hline 2011 & 41,700 & 0.09 & 1,570 & 4,230 & 3,690 & 9,930 & 68 & 182 & 65 & 176 & 0.9 & 2 & 4.8 & 13 & 322 & 865 \\
\hline 2012 & 31,600 & 0.07 & 1,690 & 4,550 & 4,410 & 11,900 & 52 & 140 & 50 & 135 & 0.6 & 2 & 4.6 & 12 & 267 & 719 \\
\hline 2013 & 106,000 & 0.22 & 13,000 & 34,900 & 38,100 & 102,000 & 87 & 234 & 85 & 230 & 20 & 53 & 29 & 78 & 1,260 & 3,390 \\
\hline 2014 & 55,600 & 0.12 & 4,760 & 12,800 & 13,100 & 35,200 & 73 & 196 & 71 & 191 & 1.4 & 4 & 12 & 32 & 584 & 1,570 \\
\hline 2015 & 51,200 & 0.11 & 5,090 & 13,700 & 14,300 & 38,500 & 67 & 180 & 65 & 176 & 1.7 & 5 & 12 & 32 & 565 & 1,520 \\
\hline 2016 & 78,600 & 0.17 & 9,420 & 25,300 & 28,000 & 75,200 & 83 & 224 & 81 & 217 & 9.0 & 24 & 21 & 56 & 898 & 2,410 \\
\hline 2017 & 85,700 & 0.18 & 7,590 & 20,400 & 21,100 & 56,600 & 107 & 288 & 104 & 280 & 4.8 & 13 & 18 & 48 & 894 & 2,400 \\
\hline 2018 & 126,000 & 0.26 & 16,900 & 45,400 & 50,700 & 136,000 & 159 & 427 & 154 & 414 & 23 & 61 & 36 & 97 & 1,520 & 4,070 \\
\hline 2019 & 180,000 & 0.38 & 20,800 & 55,800 & 59,600 & 160,000 & 153 & 411 & 150 & 403 & 36 & 98 & 47 & 126 & 2,120 & 5,700 \\
\hline $\begin{array}{c}1999- \\
2019\end{array}$ & $1,950,000$ & 4.09 & 292,000 & 785,000 & 817,000 & $2,200,000$ & 2,180 & 5,870 & 2,120 & 5,710 & 226 & 607 & 546 & 1,470 & 23,100 & 62,200 \\
\hline
\end{tabular}



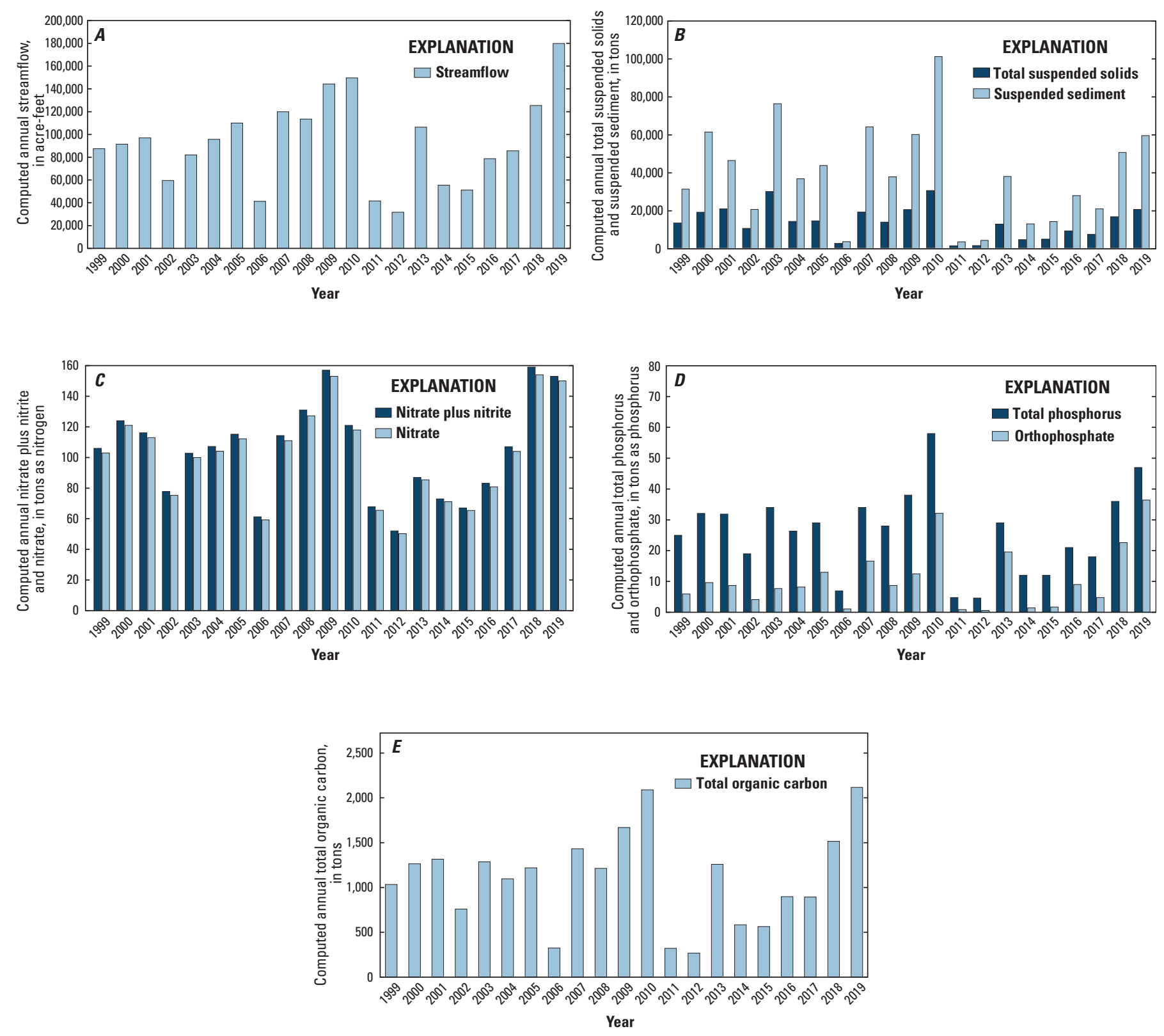

Figure 4. Computed annual loads for constituents at the North Fork Ninnescah River upstream from Cheney Reservoir (U.S. Geological Survey site 07144780), south-central Kansas, 1999 through 2019. $A$, streamflow; $B$, total suspended solids and suspended sediment; $C$, nitrate plus nitrite and nitrate; $D$, total phosphorus and orthophosphate; $E$, total organic carbon.

fertilizer absorption, large nutrient runoff may occur. Greater than average precipitation continued into the spring of 2019 , and about 78 percent of the total nitrate plus nitrite and nitrate load occurred during the first half of the year (January through June). Residual soil nitrate also likely contributed to increased nitrate loads. Agricultural practices, including fertilizer application, likely contributed to nitrate plus nitrite and nitrate loads computed at the inflow site.
$\mathrm{OP}$ and TP concentrations during the study period ranged from less than 0.01 to $0.49 \mathrm{mg} / \mathrm{L}$ (mean: $0.02 \mathrm{mg} / \mathrm{L}$ ) and less than 0.01 to $0.98 \mathrm{mg} / \mathrm{L}$ (mean: $0.12 \mathrm{mg} / \mathrm{L}$ ), respectively, based on computed daily concentrations (table 8 ). The mean TP concentration was 14 percent smaller than the mean concentration reported in Stone and others (2013a) for the period of 1999-2012 (0.14 mg/L) and could be partially due to differences in model calibration data, models, and time series data. Annual mean OP concentrations were largest during 2010 and smallest in 2012. Annual mean TP concentrations were largest 
in 2001 and smallest in 2012, corresponding to years with the second largest and smallest annual mean turbidities (fig. 4D). The EPA TP guideline for level III ecoregion 27 streams is $0.09 \mathrm{mg} / \mathrm{L}$ (U.S. Environmental Protection Agency, 2002) and was exceeded about 60 percent of the time during the study period.

The OP load was about 226 tons and the TP load was about 546 tons during 1999 through 2019 (table 9). The smallest annual load for OP and TP was during 2012 ( 0.6 ton and 4.6 tons, respectively), and the largest annual load for OP and TP was during 2019 and 2010, respectively ( 36 tons and 58 tons, respectively; table 9; fig. 4D). These loads corresponded to the smallest, largest, and second largest annual streamflows (31,600 acre-feet per year [acre-ft/ $\mathrm{yr}], 180,000 \mathrm{acre}-\mathrm{ft} / \mathrm{yr}$, and 150,000 acre-ft/yr), respectively (table 9; fig. 4A). The TP load computed using models developed for this report during 1999 through 2012 was 372 tons and about 15 percent larger than the load previously reported for the same period (328 tons; Stone and others, 2013a).

Surface-water TOC drives ecosystem energy balance and food webs, is important in the mobilization and transport of contaminants, and is associated with carcinogen formation during drinking-water treatment. TOC is a constituent of interest for Cheney Reservoir because of its role in trihalomethane formation during the water-treatment process. Trihalomethanes are disinfection byproducts that are formed when naturally existing organic materials in water react with the disinfectant's chlorine and chloramine. Trihalomethanes can cause liver, kidney, and central nervous system problems and are cancer-causing agents (U.S. Environmental Protection Agency, 2005).

Daily computed TOC concentrations ranged from less than 0.1 to $30.5 \mathrm{mg} / \mathrm{L}$ and had a mean of $6.3 \mathrm{mg} / \mathrm{L}$ during the analysis period (table 8). Annual mean TOC concentrations were largest during 2001 and smallest in 2012, corresponding to the largest and smallest annual mean turbidities. The smallest annual mean TOC concentration $(4.7 \mathrm{mg} / \mathrm{L})$ also corresponded to the smallest annual mean streamflow $\left(43.6 \mathrm{ft}^{3} / \mathrm{s}\right)$. The TOC load during 1999 through 2019 was about 23,100 tons (table 9). The smallest annual load was 267 tons in 2012, and the largest annual load was 2,120 tons in 2019 (fig. $4 E$ ). These loads corresponded to the smallest annual streamflow and the largest annual streamflow $(31,600$ acre-ft and 180,000 acre-ft), respectively (table 9; fig. 4A).

\section{Comparison of Total Suspended Solids, Nitrate, and Total Phosphorus Concentrations with Cheney Reservoir Task Force Goals}

The CRTF established base-flow and runoff goals for TSS, nitrate, and TP concentrations (Cheney Reservoir Task Force, 1994; table 1). Updated linear regression models were used to compute daily concentrations of TSS, nitrate plus nitrite, and TP to compare continuous water-quality conditions at the North Fork Ninnescah River inflow site to the
CRTF goals. Discretely sampled TSS, nitrate plus nitrite, and TP concentrations included most of the range of computed values (fig. $5 A-C$ ). Computed TSS, nitrate plus nitrite, and TP concentration data were separated into base-flow and runoff flow class conditions using the streamflow-separation point of $190 \mathrm{ft}^{3} / \mathrm{s}$.

The discrete nitrate plus nitrite dataset sample size was larger than the nitrate discrete sample dataset because of differences in available laboratory analyses at the time of sample collection (table 7). Nitrite contributed about 2.4 percent, on average, to nitrate plus nitrite in discrete samples. Because the dataset for nitrate plus nitrite was larger, had a wider range, and had a substantially larger sample collection frequency than the nitrate dataset, nitrate plus nitrite concentrations were used for comparison to CRTF goals for nitrate.

The CRTF base-flow goals were $20 \mathrm{mg} / \mathrm{L}$ for TSS, $0.25 \mathrm{mg} / \mathrm{L}$ for nitrate, and $0.05 \mathrm{mg} / \mathrm{L}$ for TP (table 1). TSS base-flow concentrations ranged from less than 1 to $916 \mathrm{mg} / \mathrm{L}$, had a mean value of $40 \mathrm{mg} / \mathrm{L}$, and exceeded the CRTF baseflow goal 70 percent of the time during base-flow conditions (table 10). Base-flow nitrate plus nitrite concentrations ranged from 0.20 to $1.82 \mathrm{mg} / \mathrm{L}$, had a mean value of $1.04 \mathrm{mg} / \mathrm{L}$, and exceeded the CRTF goal 99.9 percent of the time during base-flow conditions (table 10). TP base-flow concentrations ranged from less than 0.01 to $0.75 \mathrm{mg} / \mathrm{L}$, had a mean value of $0.11 \mathrm{mg} / \mathrm{L}$, and exceeded the CRTF goal 91 percent of the time during base-flow conditions (table 10). TSS, nitrate plus nitrite, and TP base-flow percentage exceedances for the analysis period were similar (less than a 10-percent difference): 9 percent smaller, nearly equal to, and 4 percent smaller, respectively, than those reported for the period 1999-2012 in Stone and others (2013a).

The CRTF runoff goals were $550 \mathrm{mg} / \mathrm{L}$ for TSS, $6.6 \mathrm{mg} / \mathrm{L}$ for nitrate, and $0.4 \mathrm{mg} / \mathrm{L}$ for TP (table 1). TSS runoff concentrations ranged from 14.9 to $1,220 \mathrm{mg} / \mathrm{L}$, had a mean value of $138 \mathrm{mg} / \mathrm{L}$, and exceeded the CRTF runoff goal about 1.4 percent of the time during runoff conditions (table 10). Nitrate plus nitrite runoff concentrations ranged from 0.04 to $1.71 \mathrm{mg} / \mathrm{L}$, had a mean value of $0.70 \mathrm{mg} / \mathrm{L}$, and never exceeded the CRTF runoff goal (table 10). TP runoff concentrations ranged from 0.06 to $0.98 \mathrm{mg} / \mathrm{L}$, had a mean value of $0.25 \mathrm{mg} / \mathrm{L}$, and exceeded the CRTF runoff goal 11 percent of the time during runoff conditions (table 10). TSS, nitrate plus nitrite, and TP runoff percentage exceedances for the study period were similar to previous exceedances: 1.6 percent smaller, equal to, and 5 percent smaller, respectively, than those reported for the period 1999-2012 (Stone and others, 2013a).

Annual mean TSS, nitrate plus nitrite, and TP concentrations for base-flow and runoff streamflow conditions were also compared to CRTF goals. Except for 2012, annual mean TSS concentrations during base-flow conditions exceeded the base-flow goal $(20 \mathrm{mg} / \mathrm{L})$ every year. Annual mean TSS concentrations during runoff conditions never exceeded the CRTF runoff goal of $550 \mathrm{mg} / \mathrm{L}$ (fig. $6 B$ ) during the analysis period or previously reported periods (1997 through 2012; 

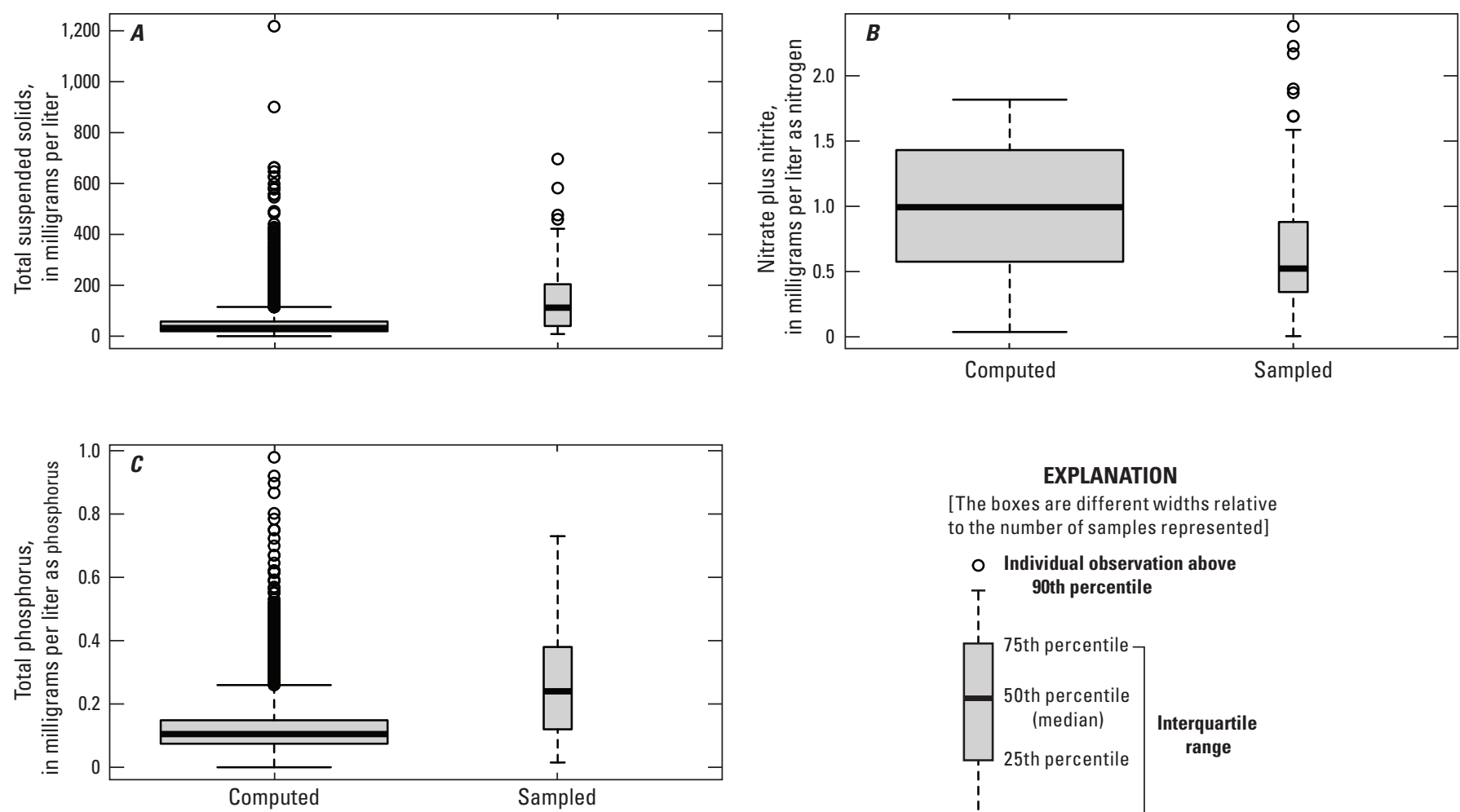

EXPLANATION

[The boxes are different widths relative to the number of samples represented]

○ Individual observation above

T 90th percentile

1

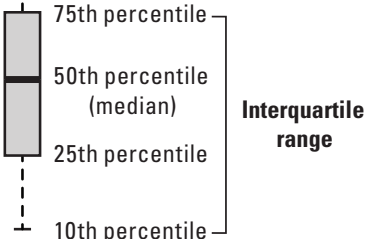

Figure 5. Model-computed daily (1999-2019) and sampled concentrations (1999-2017) for constituents at the North Fork Ninnescah River upstream from Cheney Reservoir (U.S. Geological Survey site 07144780), south-central Kansas. $A$, total suspended solids; $B$, nitrate plus nitrite; $C$, total phosphorus.

Table 10. Summary statistics for selected water-quality constituents computed with updated regression models and daily mean values of continuously measured physical properties at the North Fork Ninnescah River upstream from Cheney Reservoir (U.S. Geological Survey site 07144780), south-central Kansas, 1999 through 2019.

[Continuous real-time water-quality data and daily values are available on the U.S. Geological Survey National Real-Time Water Quality website (https://nrtwq.usgs.gov/ks); $n$, number of measurements; mg/L, milligram per liter; $<$, less than]

\begin{tabular}{|c|c|c|c|c|c|}
\hline \multirow[b]{2}{*}{ Water-quality constituent } & \multicolumn{5}{|c|}{ Flow condition } \\
\hline & $n$ & Range & Mean & Median & $\begin{array}{c}\text { Frequency of exceedance of } \\
\text { Cheney Reservoir Task Force } \\
\text { goal', in percent }\end{array}$ \\
\hline \multicolumn{6}{|c|}{ Base flow } \\
\hline Total suspended solids (mg/L) & 6,901 & $<1-916$ & 40 & 29 & 70 \\
\hline Nitrate plus nitrite (mg/L) & 6,901 & $0.20-1.82$ & 1.04 & 1.04 & 99.9 \\
\hline \multicolumn{6}{|c|}{ Runoff } \\
\hline Total suspended solids (mg/L) & 769 & $14.9-1,220$ & 138 & 108 & 1.4 \\
\hline Nitrate plus nitrite (mg/L) & 769 & $0.04-1.71$ & 0.70 & 0.59 & 0 \\
\hline Total phosphorus (mg/L) & 769 & $0.06-0.98$ & 0.25 & 0.22 & 11 \\
\hline
\end{tabular}

${ }^{1}$ Cheney Reservoir Task Force, 1994. 

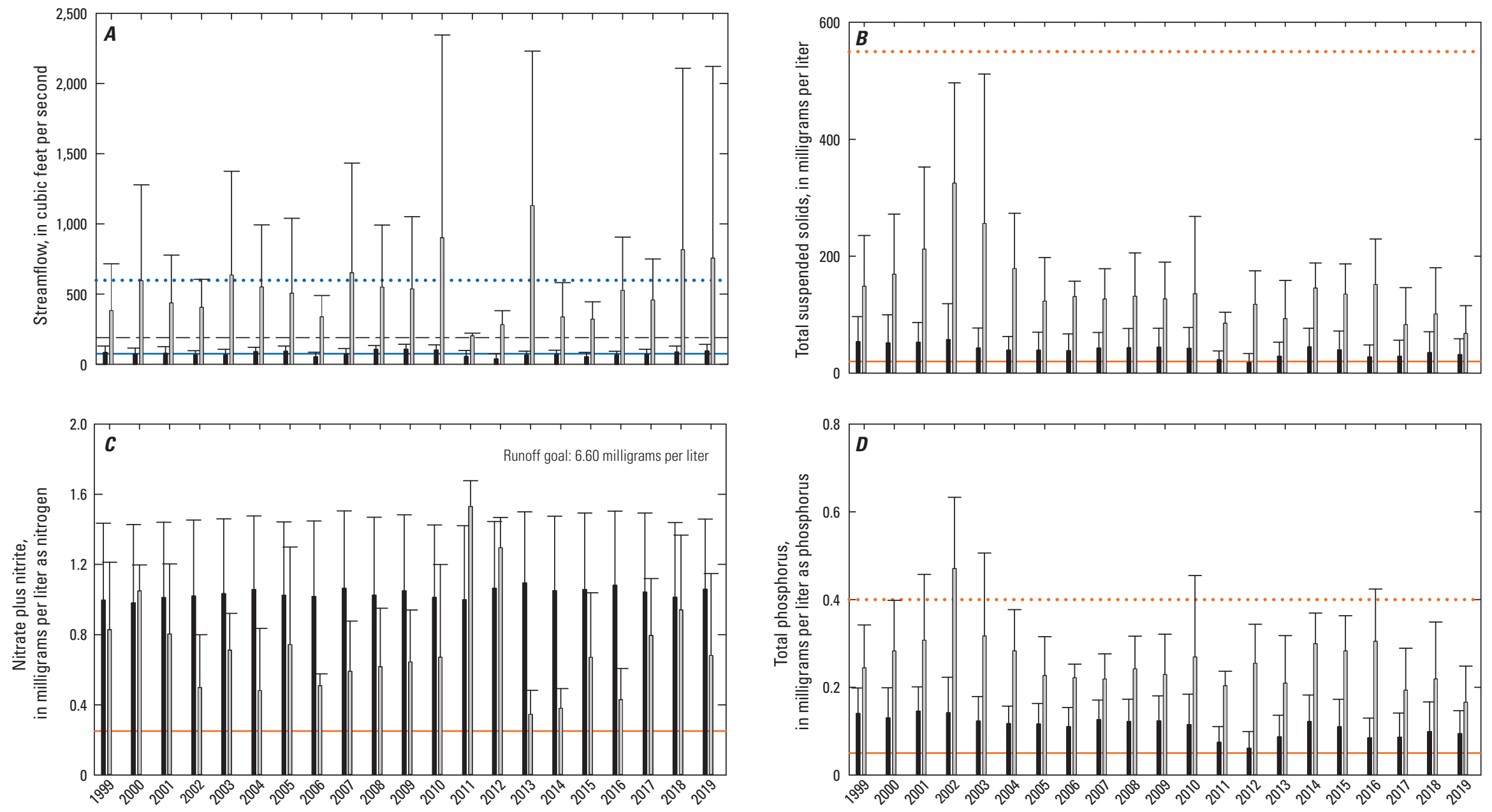

\section{EXPLANATION}
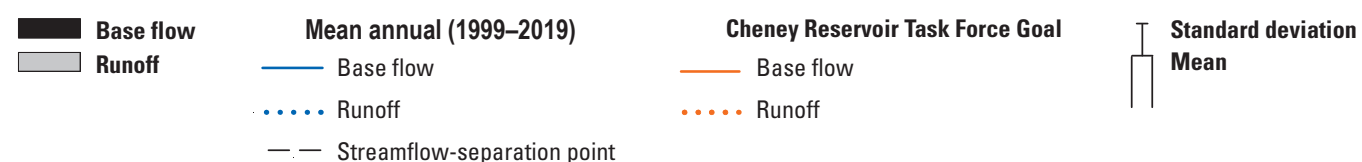

Figure 6. Annual mean computed values during base-flow and runoff streamflow conditions at the North Fork Ninnescah River upstream from Cheney Reservoir (U.S. Geological Survey site 07144780), south-central Kansas, 1999 through 2019. $A$, streamflow; $B$, computed total suspended solids; $C$, computed nitrate plus nitrite; $D$, computed total phosphorus concentrations. 
Stone and others, 2009, 2013a). Annual mean nitrate plus nitrite concentrations during base-flow conditions exceeded the base-flow goal $(0.25 \mathrm{mg} / \mathrm{L})$ every year by $3.5-4.5$ times during the study (fig. 6C), indicating that the base-flow goal may not be attainable. Previously reported annual mean nitrate plus nitrite concentrations exceeded the base-flow goal each year during 1999 through 2012 by about four to five times (Stone and others, 2013a). The nitrate runoff goal $(6.60 \mathrm{mg} / \mathrm{L})$ was never exceeded during this study (table 10$)$. Nitrate plus nitrite concentrations at the inflow site seem to be diluted by increased streamflow during runoff conditions because the annual mean nitrate plus nitrite concentrations were larger during base-flow conditions rather than during runoff conditions (fig. 6C). In 2011 and 2012, the two years with lowest annual mean streamflow, mean runoff nitrate plus nitrite concentrations were larger than mean base-flow concentrations. In these years, runoff events occurred during winter and spring months (2011, February and December; 2012, February and March). Nitrate plus nitrite concentrations were consistently largest during October through March and smallest during April through September. Annual mean TP concentrations during base-flow conditions exceeded the CRTF base-flow goal $(0.05 \mathrm{mg} / \mathrm{L})$ every year of this study by about two to three times, which was consistent with previously reported annual mean TP concentrations (Stone and others, 2009, 2013a). The runoff TP goal $(0.40 \mathrm{mg} / \mathrm{L})$ was exceeded only in 2002 (fig. $6 D$ ), a year with larger annual mean turbidity.

Base-flow goals for TSS, nitrate plus nitrite, and TP were exceeded more frequently than runoff goals (70 to 99.9 percent of the time compared to 0 to 12 percent of the time). Natural background phosphorus and groundwater nitrate concentrations likely cause exceedances for established base-flow goals even during extremely dry years, indicating base-flow goals may continue to be unattainable or substantially more or different types of BMPs may need to be implemented to meet them (Pope and others, 2002; Stone and others, 2009, 2013a).

\section{Weighted Regressions on Time, Discharge, and Season Models}

The North Fork Ninnescah River sediment and nutrient temporal trends have not been evident largely because of hydrologic variability (Stone and others, 2009, 2013a, 2015; Graham and others, 2017). Statistical procedures using the WRTDS approach within the EGRET R package allow for model creation to examine concentration behavior as a function of time, discharge, and season (Hirsch and De Cicco, 2015). WRTDS can be used to estimate annual or seasonal mean water-quality constituent concentrations and fluxes and to describe long-term water-quality constituent trends.

The WBT in the EGRETci R package estimates waterquality trends and quantifies WRTDS estimate uncertainty (Hirsch and others, 2015). TSS, SSC, nitrate plus nitrite, OP,
TP, and TOC concentration and flux estimates; long-term trends; and uncertainty were analyzed using EGRET and EGRETci R packages. WRTDS model evaluation and WBT output for each constituent are provided in appendixes 19-24. Cheney Reservoir inflow long-term trends using this statistical approach for TSS, nitrate plus nitrite, and TP were compared to the CRTF long-term goals (Cheney Reservoir Task Force, 1994; table 1).

\section{Computed Load Comparisons}

Annual concentration computations, flow-normalized concentrations, flux, and flow-normalized flux are shown in tables 11 and 12. Flow-based flux computations using WRTDS models for TSS, SSC, nitrate plus nitrite, OP, TP, and TOC during 1999 through 2019 had mean RPDs ranging from -3 to 25 percent from the loads computed using linear regression models (fig. 7). Total computed flux values from the flowbased models were generally greater than the loads computed using linear regression models except for OP and TOC, which were slightly smaller over the analysis period (fig. 7).

There were limitations using linear regression models for water-quality constituent computations because of changes in sensor technology during the study period and resultant sample sizes. Computed concentrations and loads using YSI EXO turbidity sensor data (November 2015 through December 2019) may be underestimated. This was a concern for computed loads in 2019, which had the highest annual streamflow, yet most of the modeled constituent loads (using linear regression models) were larger in 2010 (the year with second largest annual streamflow). The WRTDS computed loads were larger than linear regression model-computed loads for every constituent in 2019 and most were substantially larger in alignment with what would be expected during a year with above-normal flooding.

\section{Trend Tests}

Annual flow-normalized concentration (fig. 8) and flow-normalized flux (fig. 9) plots with trendlines and 90-percent confidence intervals were produced for all modeled constituents. The flow-normalized concentration and flux uncertainty bands can widen at the end of temporal plots or during periods throughout the analysis period because a linear relation is not assumed; therefore, the confidence interval can diverge much more substantially than with linear regression. Confidence interval divergences could be indicative of changes that increase inherent variability (for example, process changes, changes in sample density, changes in drainage basin management, and so on; Hirsch and others, 2015). Some annual estimates plot outside the confidence band because of large annual streamflow variability (Hirsch and others, 2015). 
Table 11. Computed concentrations and flow-normalized concentrations for selected water-quality constituents at the North Fork Ninnescah River upstream from Cheney Reservoir (U.S. Geological Survey site 07144780), south-central Kansas, 1999 through 2019

[Computations for annual concentrations are from Weighted Regressions on Time, Discharge, and Season models; ft3/s, cubic foot per second; mg/L, milligram per liter]

\begin{tabular}{|c|c|c|c|c|c|c|c|c|c|c|c|c|c|}
\hline \multirow[b]{2}{*}{ 离 } & \multirow{2}{*}{ 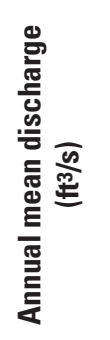 } & \multicolumn{2}{|c|}{$\begin{array}{l}\text { Total suspended solids } \\
\text { (mg/L) }\end{array}$} & \multicolumn{2}{|c|}{$\begin{array}{c}\text { Suspended-sediment } \\
\text { concentration } \\
(\mathrm{mg} / \mathrm{L})\end{array}$} & \multicolumn{2}{|c|}{$\begin{array}{l}\text { Nitrate plus nitrite } \\
\text { (mg/L) }\end{array}$} & \multicolumn{2}{|c|}{$\begin{array}{l}\text { Orthophosphate } \\
\text { (mg/L) }\end{array}$} & \multicolumn{2}{|c|}{$\begin{array}{l}\text { Total phosphorus } \\
\text { (mg/L) }\end{array}$} & \multicolumn{2}{|c|}{$\begin{array}{l}\text { Total organic carbon } \\
(\mathrm{mg} / \mathrm{L})\end{array}$} \\
\hline & & 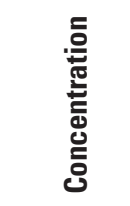 & 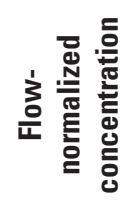 & 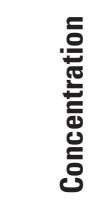 & 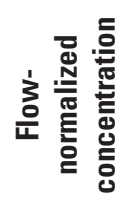 & 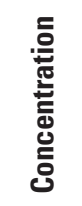 & 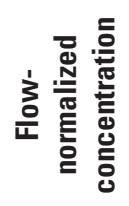 & 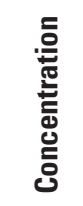 & 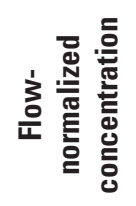 & 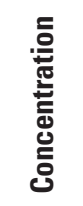 & 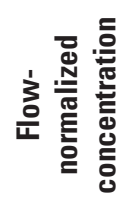 & 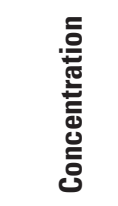 & 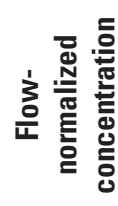 \\
\hline 1999 & 121 & 72.9 & 66.4 & 114 & 115 & 1.35 & 1.34 & 0.02 & 0.02 & 0.13 & 0.13 & 5.29 & 4.94 \\
\hline 2000 & 126 & 64.9 & 66.3 & 135 & 116 & 1.22 & 1.30 & 0.02 & 0.02 & 0.13 & 0.13 & 5.50 & 5.08 \\
\hline 2001 & 134 & 73.8 & 66.2 & 129 & 118 & 1.25 & 1.26 & 0.02 & 0.02 & 0.14 & 0.13 & 5.59 & 5.23 \\
\hline 2002 & 82.5 & 54.0 & 66.4 & 88 & 119 & 1.27 & 1.24 & 0.01 & 0.02 & 0.12 & 0.14 & 4.94 & 5.44 \\
\hline 2003 & 113 & 60.3 & 66.7 & 104 & 120 & 1.21 & 1.20 & 0.02 & 0.02 & 0.13 & 0.14 & 5.37 & 5.61 \\
\hline 2004 & 132 & 77.1 & 67.1 & 132 & 122 & 1.20 & 1.18 & 0.03 & 0.02 & 0.16 & 0.14 & 6.28 & 5.81 \\
\hline 2005 & 152 & 82.8 & 68.4 & 146 & 123 & 1.17 & 1.14 & 0.03 & 0.02 & 0.17 & 0.15 & 6.75 & 6.04 \\
\hline 2006 & 57.2 & 44.3 & 69.8 & 64 & 125 & 1.09 & 1.09 & 0.01 & 0.02 & 0.11 & 0.15 & 5.09 & 6.27 \\
\hline 2007 & 166 & 78.9 & 69.6 & 146 & 127 & 1.10 & 1.05 & 0.02 & 0.02 & 0.16 & 0.15 & 6.89 & 6.43 \\
\hline 2008 & 156 & 88.9 & 69.8 & 167 & 129 & 1.04 & 1.04 & 0.02 & 0.02 & 0.18 & 0.15 & 7.56 & 6.52 \\
\hline 2009 & 200 & 98.1 & 70.6 & 202 & 132 & 1.02 & 1.04 & 0.02 & 0.02 & 0.20 & 0.15 & 7.96 & 6.48 \\
\hline 2010 & 207 & 87.8 & 72.7 & 172 & 136 & 1.08 & 1.06 & 0.03 & 0.03 & 0.18 & 0.16 & 7.26 & 6.41 \\
\hline 2011 & 57.6 & 49.1 & 75.1 & 78 & 141 & 1.00 & 1.08 & 0.01 & 0.03 & 0.12 & 0.16 & 5.10 & 6.29 \\
\hline 2012 & 43.6 & 38.4 & 76.6 & 61 & 147 & 0.93 & 1.10 & 0.01 & 0.03 & 0.10 & 0.16 & 4.40 & 6.18 \\
\hline 2013 & 147 & 67.5 & 78.2 & 139 & 153 & 1.17 & 1.11 & 0.03 & 0.03 & 0.15 & 0.16 & 5.58 & 6.03 \\
\hline 2014 & 76.7 & 70.3 & 80.1 & 123 & 159 & 1.18 & 1.11 & 0.02 & 0.03 & 0.14 & 0.16 & 5.36 & 5.91 \\
\hline 2015 & 70.8 & 63.1 & 81.2 & 117 & 165 & 1.13 & 1.11 & 0.02 & 0.03 & 0.13 & 0.16 & 5.09 & 5.81 \\
\hline 2016 & 109 & 75.5 & 82.6 & 155 & 171 & 1.21 & 1.12 & 0.03 & 0.03 & 0.15 & 0.16 & 5.30 & 5.71 \\
\hline 2017 & 188 & 86.2 & 83.7 & 178 & 177 & 1.15 & 1.12 & 0.03 & 0.03 & 0.16 & 0.16 & 5.64 & 5.58 \\
\hline 2018 & 174 & 89.6 & 84.8 & 234 & 184 & 1.08 & 1.12 & 0.04 & 0.03 & 0.18 & 0.16 & 5.68 & 5.50 \\
\hline 2019 & 248 & 111 & 86.8 & 265 & 193 & 1.08 & 1.12 & 0.05 & 0.03 & 0.20 & 0.16 & 6.46 & 5.42 \\
\hline
\end{tabular}


Table 12. Computed constituent flux and flow-normalized flux for selected water-quality constituents at the North Fork Ninnescah River upstream from Cheney Reservoir (U.S. Geological Survey site 07144780), south-central Kansas, 1999 through 2019.

[Estimations in annual flux are from Weighted Regressions on Time, Discharge, and Season models; $\mathrm{ft}^{3} / \mathrm{s}$, cubic foot per second; yr, year]

\begin{tabular}{|c|c|c|c|c|c|c|c|c|c|c|c|c|c|}
\hline \multirow{2}{*}{ Year } & \multirow{2}{*}{$\begin{array}{c}\text { Annual } \\
\text { mean } \\
\text { discharge } \\
\left(\mathrm{ft}^{3} / \mathrm{s}\right)\end{array}$} & \multicolumn{2}{|c|}{$\begin{array}{c}\text { Total suspended solids } \\
\text { (tons/yr) }\end{array}$} & \multicolumn{2}{|c|}{$\begin{array}{c}\text { Suspended-sediment } \\
\text { concentration } \\
\text { (tons/yr) }\end{array}$} & \multicolumn{2}{|c|}{$\begin{array}{c}\text { Nitrate plus nitrite } \\
\text { (tons/yr) }\end{array}$} & \multicolumn{2}{|c|}{$\begin{array}{l}\text { Orthophosphate } \\
\text { (tons/yr) }\end{array}$} & \multicolumn{2}{|c|}{$\begin{array}{l}\text { Total phosphorus } \\
\text { (tons/yr) }\end{array}$} & \multicolumn{2}{|c|}{$\begin{array}{l}\text { Total organic carbon } \\
\text { (tons/yr) }\end{array}$} \\
\hline & & Flux & $\begin{array}{l}\text { Flow- } \\
\text { normalized } \\
\text { flux }\end{array}$ & Flux & $\begin{array}{l}\text { Flow- } \\
\text { normalized } \\
\text { flux }\end{array}$ & Flux & $\begin{array}{l}\text { Flow- } \\
\text { normalized } \\
\text { flux }\end{array}$ & Flux & $\begin{array}{l}\text { Flow- } \\
\text { normalized } \\
\text { flux }\end{array}$ & Flux & $\begin{array}{l}\text { Flow- } \\
\text { normalized } \\
\text { flux }\end{array}$ & Flux & $\begin{array}{l}\text { Flow- } \\
\text { normalized } \\
\text { flux }\end{array}$ \\
\hline 1999 & 121 & 14,500 & 8,600 & 29,500 & 58,500 & 135 & 128 & 4.49 & 7.99 & 21.4 & 27.7 & 837 & 970 \\
\hline 2000 & 126 & 19,500 & 18,100 & 85,500 & 57,800 & 134 & 126 & 6.39 & 8.27 & 30.1 & 28.1 & 964 & 992 \\
\hline 2001 & 134 & 18,900 & 17,800 & 44,200 & 57,700 & 138 & 124 & 6.64 & 8.56 & 27.5 & 28.6 & 1,080 & 1,020 \\
\hline 2002 & 82.5 & 7,200 & 17,500 & 15,400 & 57,300 & 101 & 122 & 2.63 & 8.83 & 14.1 & 29.2 & 495 & 1,050 \\
\hline 2003 & 113 & 18,000 & 17,200 & 61,600 & 57,100 & 111 & 121 & 6.12 & 9.12 & 26.4 & 29.8 & 994 & 1,080 \\
\hline 2004 & 132 & 16,800 & 16,900 & 41,900 & 56,600 & 127 & 119 & 7.90 & 9.41 & 29.0 & 30.2 & 1,110 & 1,110 \\
\hline 2005 & 152 & 19,400 & 16,900 & 48,200 & 56,500 & 139 & 116 & 11.7 & 9.65 & 35.3 & 30.9 & 1,390 & 1,150 \\
\hline 2006 & 57.2 & 3,340 & 16,700 & 5,030 & 56,000 & 69.5 & 111 & 0.99 & 9.91 & 7.07 & 31.2 & 319 & 1,190 \\
\hline 2007 & 166 & 26,200 & 16,300 & 80,500 & 55,600 & 119 & 110 & 15.1 & 9.90 & 44.6 & 31.2 & 1,820 & 1,210 \\
\hline 2008 & 156 & 18,900 & 15,900 & 50,300 & 54,800 & 137 & 109 & 10.2 & 9.88 & 36.7 & 31.4 & 1,470 & 1,230 \\
\hline 2009 & 200 & 28,600 & 15,700 & 82,700 & 54,400 & 159 & 109 & 15.6 & 9.90 & 52.8 & 31.6 & 2,090 & 1,220 \\
\hline 2010 & 207 & 24,800 & 15,900 & 106,000 & 54,100 & 140 & 110 & 26.1 & 10.0 & 59.1 & 32.1 & 2,230 & 1,220 \\
\hline 2011 & 57.6 & 3,890 & 16,100 & 6,600 & 54,100 & 77.8 & 111 & 0.82 & 10.2 & 7.28 & 32.6 & 318 & 1,200 \\
\hline 2012 & 43.6 & 3,100 & 16,100 & 5,490 & 54,200 & 57.8 & 112 & 0.63 & 10.5 & 5.43 & 32.9 & 234 & 1,180 \\
\hline 2013 & 147 & 15,000 & 16,200 & 71,500 & 54,800 & 93.5 & 113 & 19.8 & 10.7 & 46.6 & 33.4 & 1,480 & 1,170 \\
\hline 2014 & 76.7 & 6,620 & 16,300 & 13,000 & 55,300 & 87.2 & 113 & 2.70 & 10.9 & 12.9 & 33.8 & 471 & 1,150 \\
\hline 2015 & 70.8 & 6,780 & 16,200 & 14,800 & 55,700 & 76.9 & 113 & 2.69 & 11.1 & 12.3 & 34.2 & 457 & 1,140 \\
\hline 2016 & 109 & 11,600 & 16,200 & 34,400 & 56,000 & 94.3 & 113 & 9.09 & 11.4 & 27.9 & 34.5 & 863 & 1,130 \\
\hline 2017 & 188 & 16,400 & 16,200 & 42,300 & 56,700 & 112 & 113 & 7.39 & 11.6 & 28.8 & 34.9 & 972 & 1,110 \\
\hline 2018 & 174 & 17,700 & 16,100 & 139,000 & 57,300 & 126 & 112 & 22.8 & 11.9 & 56.2 & 35.3 & 1,520 & 1,100 \\
\hline 2019 & 248 & 38,200 & 16,200 & 168,000 & 58,100 & 161 & 112 & 38.7 & 12.2 & 91.5 & 35.7 & 2,840 & 1,090 \\
\hline
\end{tabular}



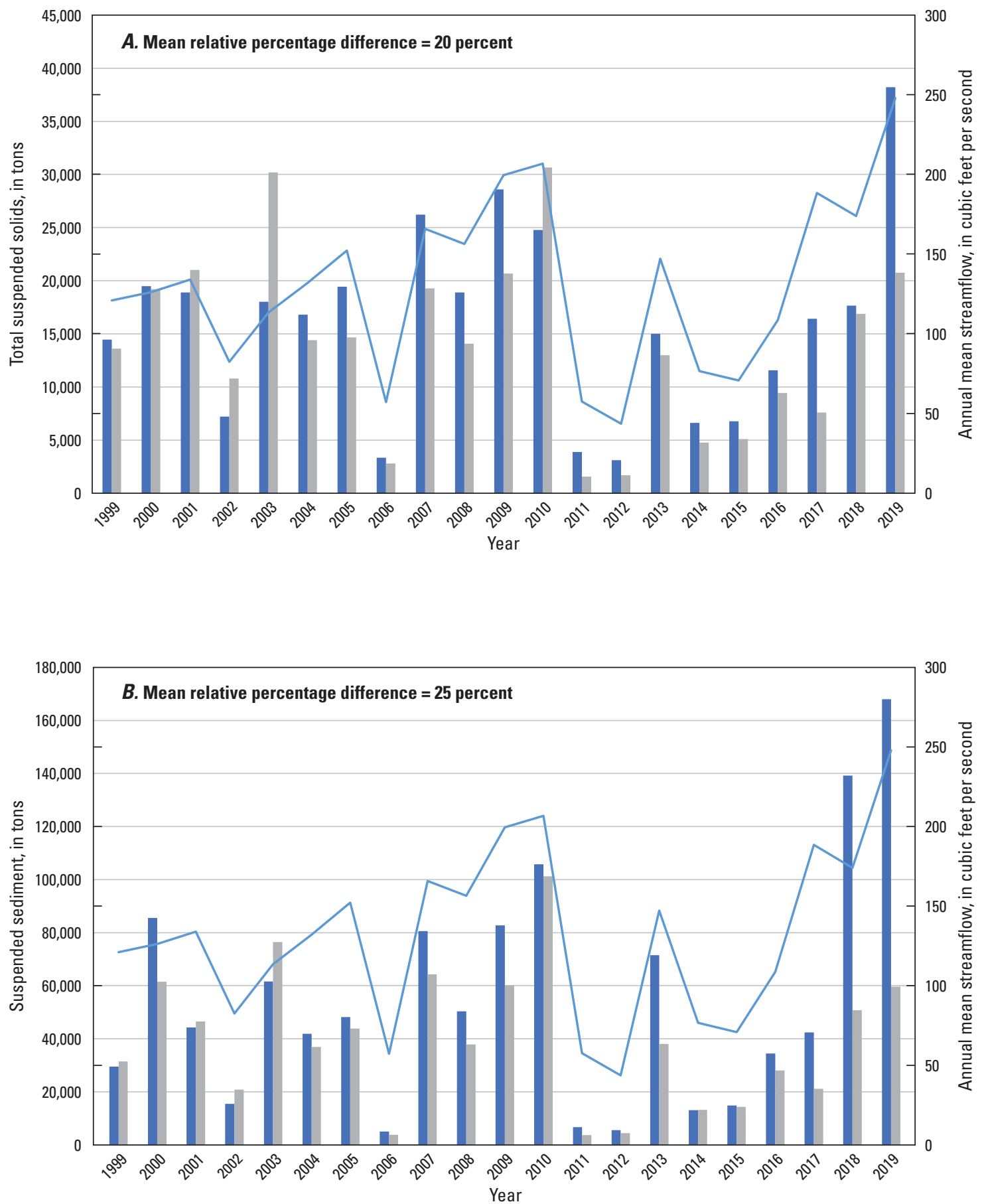

EXPLANATION

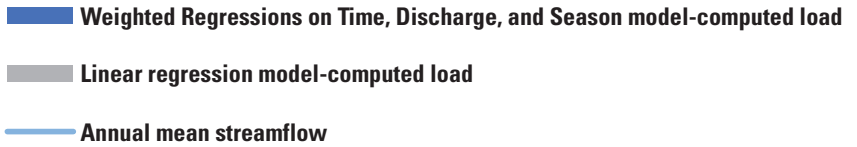

Figure 7. Model-computed load comparisons between Weighted Regressions on Time, Discharge, and Season model and linear regression developed models, 1999 through 2019. $A$, total suspended solids; $B$, suspended sediment; $C$, nitrate plus nitrite; $D$, orthophosphate; $E$, total phosphorus; $F$, total organic carbon. 

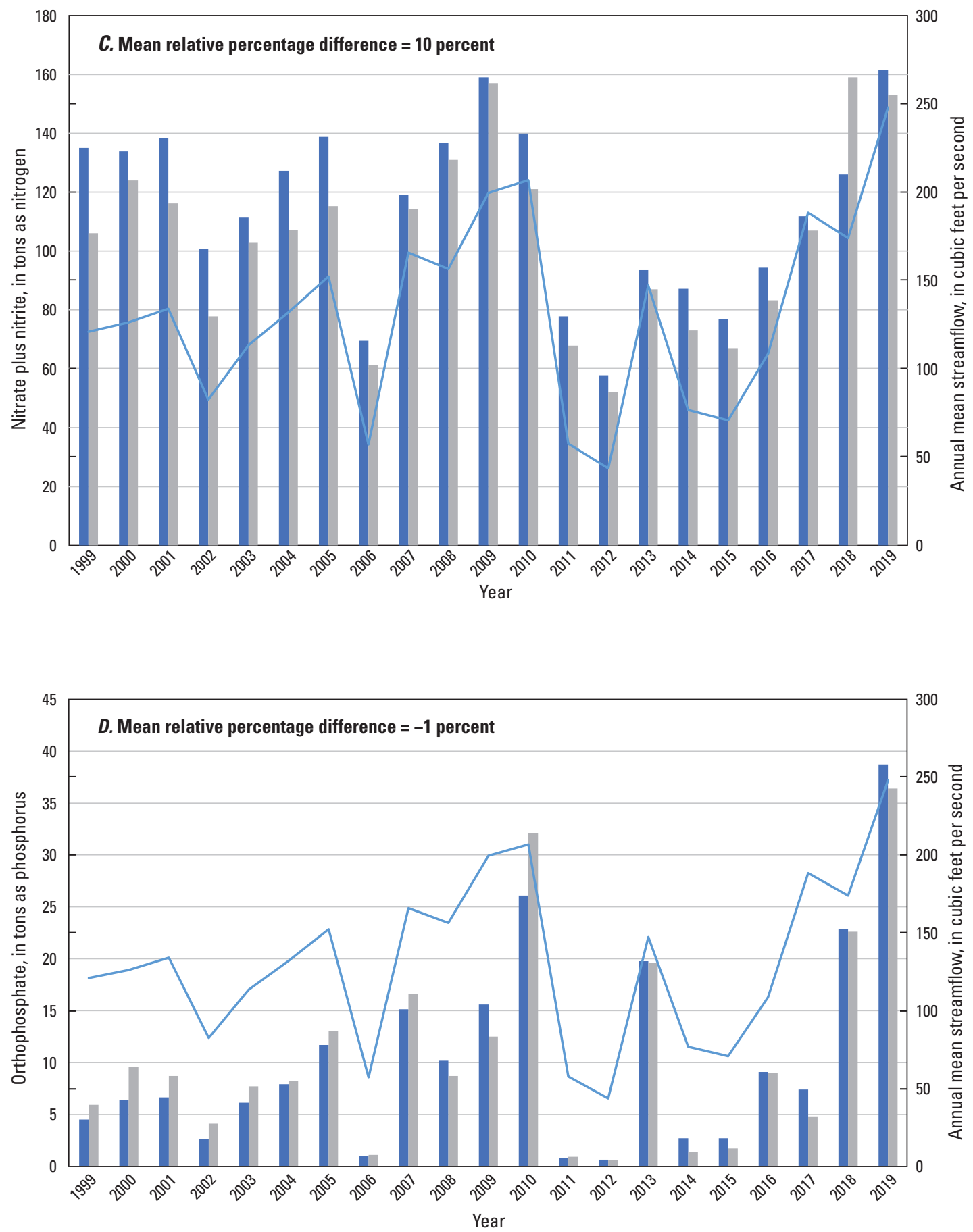

EXPLANATION

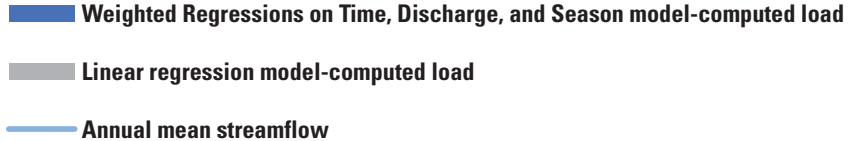

Figure 7. Model-computed load comparisons between Weighted Regressions on Time, Discharge, and Season model and linear regression developed models, 1999 through 2019. $A$, total suspended solids; $B$, suspended sediment; $C$, nitrate plus nitrite; $D$, orthophosphate; $E$, total phosphorus; $F$, total organic carbon.-Continued 

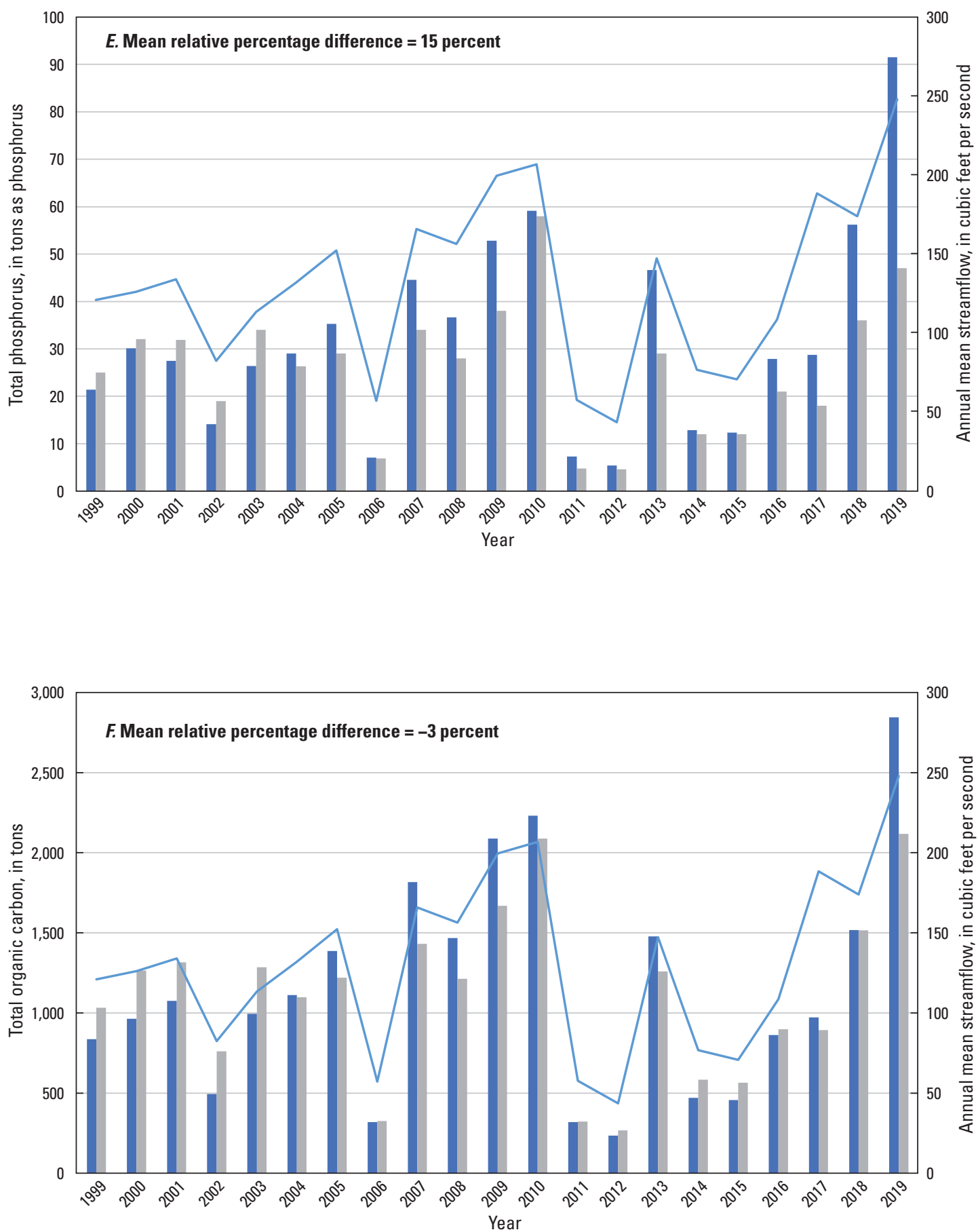

EXPLANATION

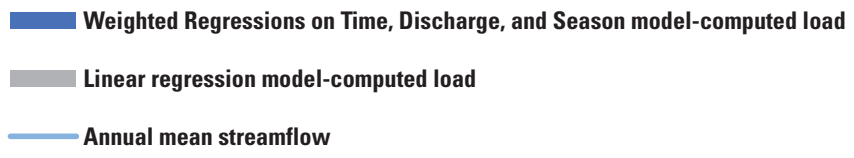

Figure 7. Model-computed load comparisons between Weighted Regressions on Time, Discharge, and Season model and linear regression developed models, 1999 through 2019. $A$, total suspended solids; $B$, suspended sediment; $C$, nitrate plus nitrite; $D$, orthophosphate; $E$, total phosphorus; $F$, total organic carbon.-Continued 


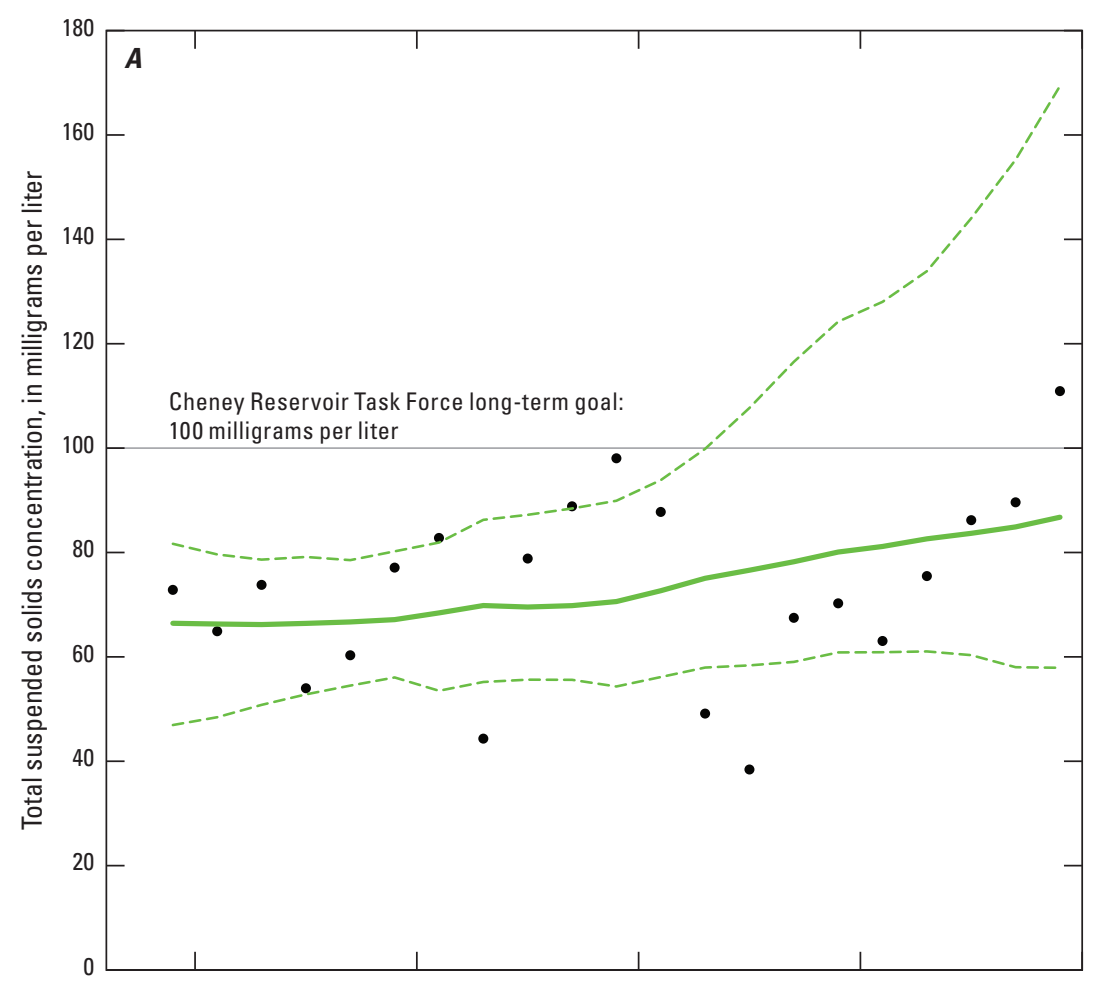

EXPLANATION

- Flow-normalized concentration

90-percent confidence interval on flow-normalized concentration

- Annual mean concentration

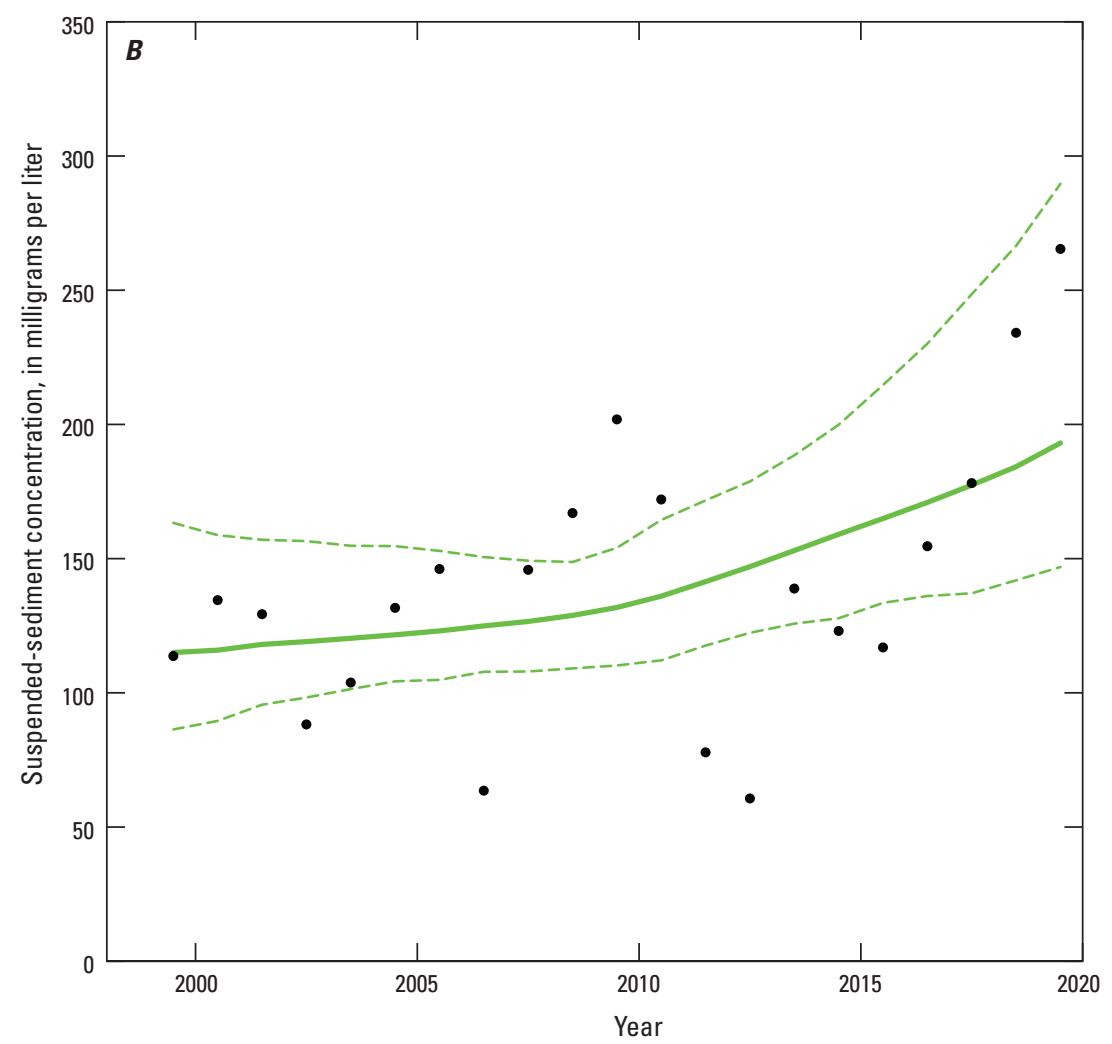

Figure 8. Annual mean concentrations with flow-normalized concentration trend and 90-percent confidence interval for constituents at the North Fork Ninnescah River upstream from Cheney Reservoir (U.S. Geological Survey site 07144780), south-central Kansas, 1999 through 2019. $A$, total suspended solids; $B$, suspended sediment; $C$, nitrate plus nitrite; $D$, orthophosphate; $E$, total phosphorus; $F$, total organic carbon. 


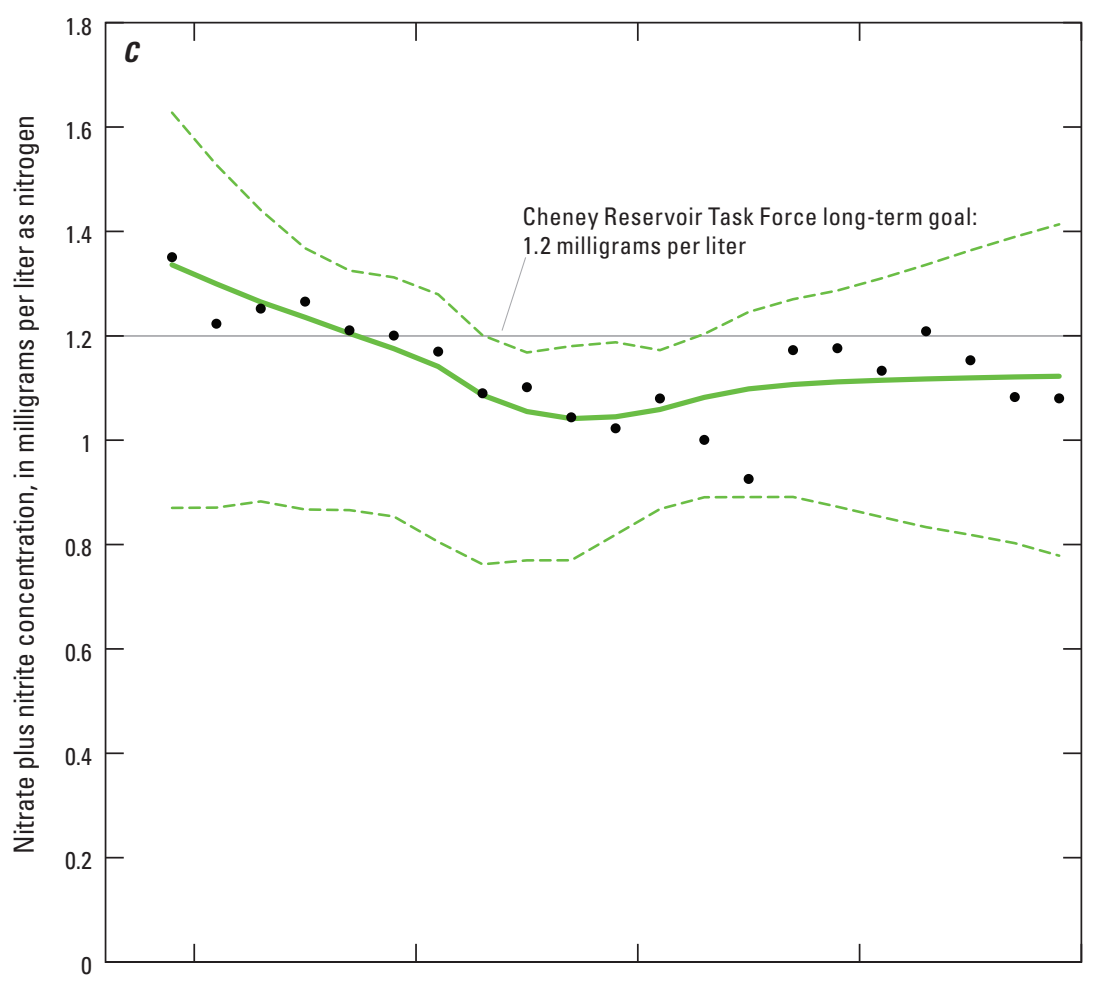

EXPLANATION

Flow-normalized concentration

90-percent confidence interval on flow-normalized concentration

- Annual mean concentration

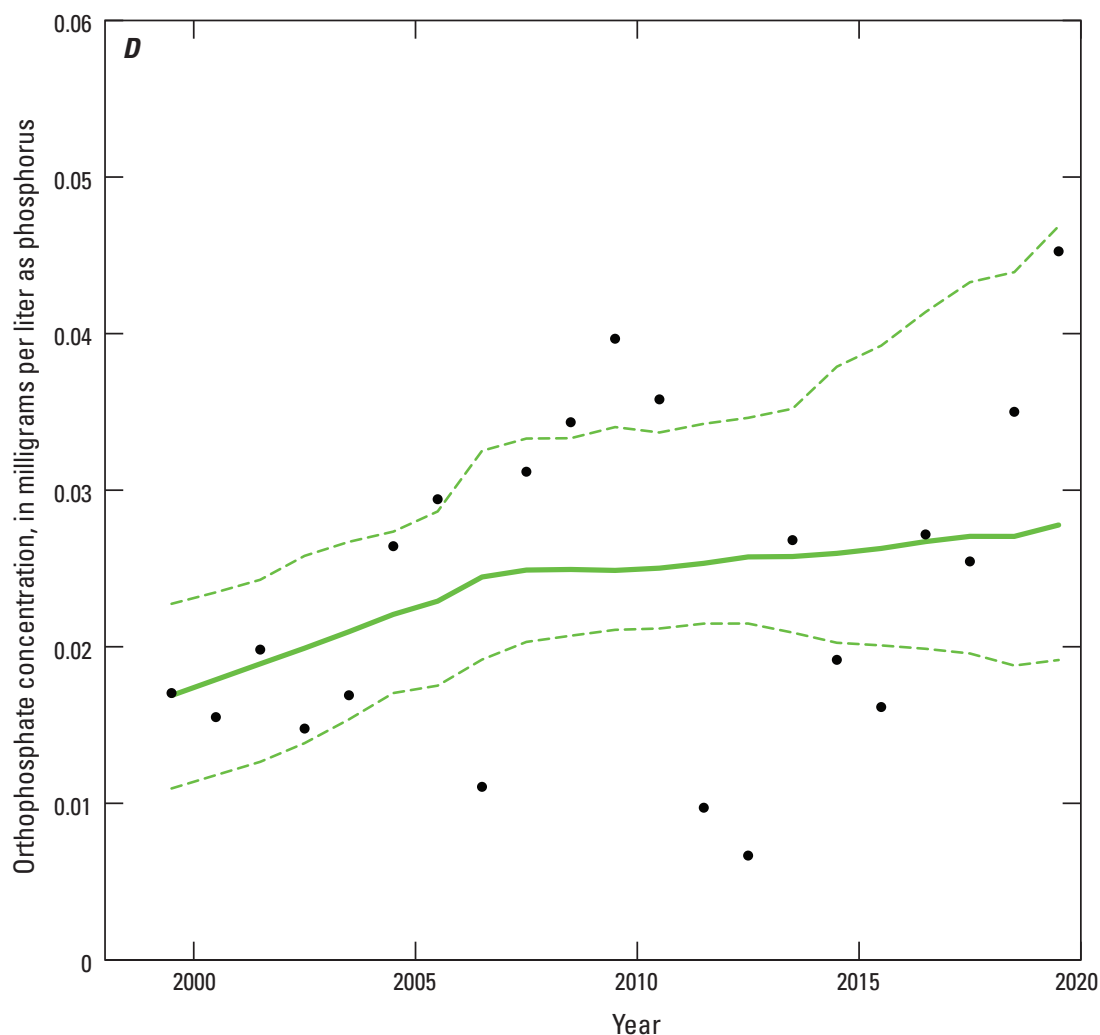

Figure 8. Annual mean concentrations with flow-normalized concentration trend and 90-percent confidence interval for constituents at the North Fork Ninnescah River upstream from Cheney Reservoir (U.S. Geological Survey site 07144780), south-central Kansas, 1999 through 2019. $A$, total suspended solids; $B$, suspended sediment; $C$, nitrate plus nitrite; $D$, orthophosphate; $E$, total phosphorus; $F$, total organic carbon.-Continued 


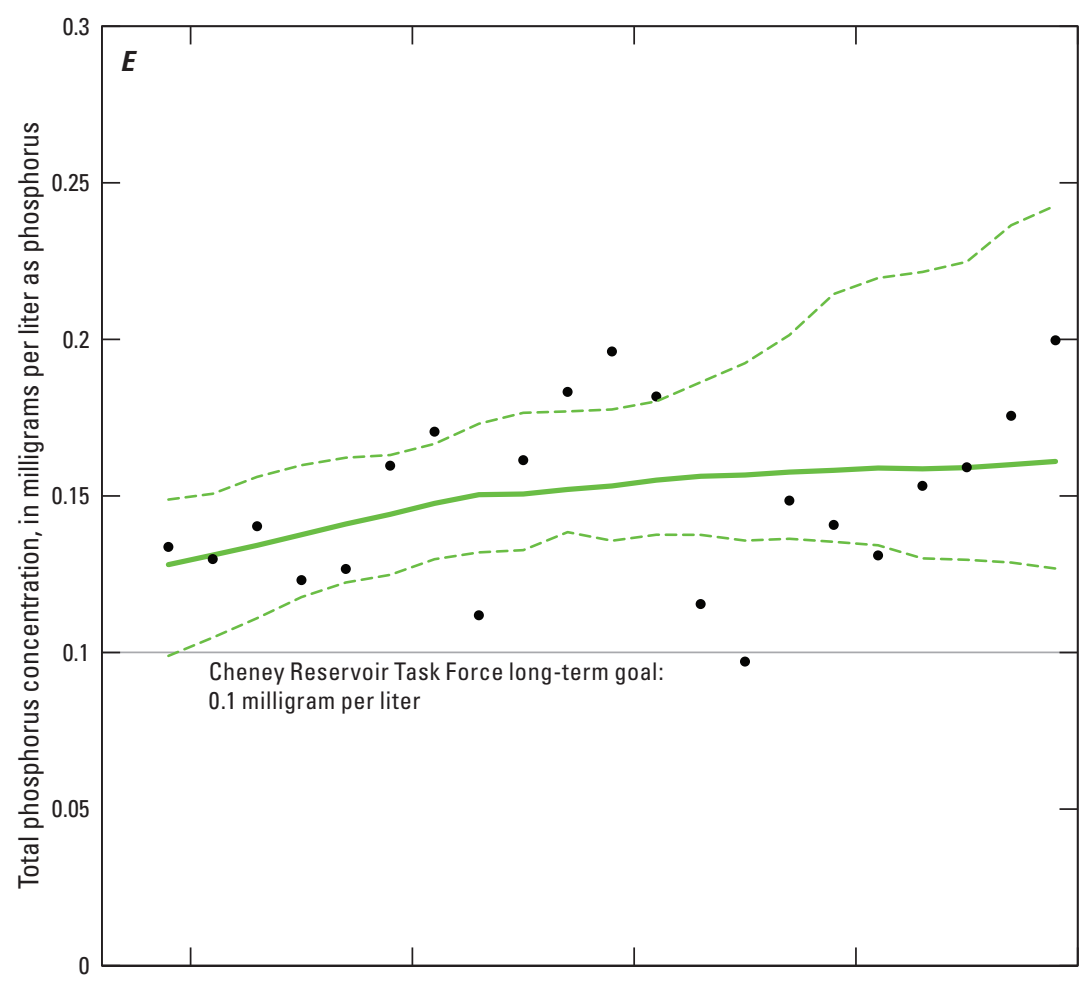

EXPLANATION

Flow-normalized concentration

90-percent confidence interval on flow-normalized concentration

- Annual mean concentration

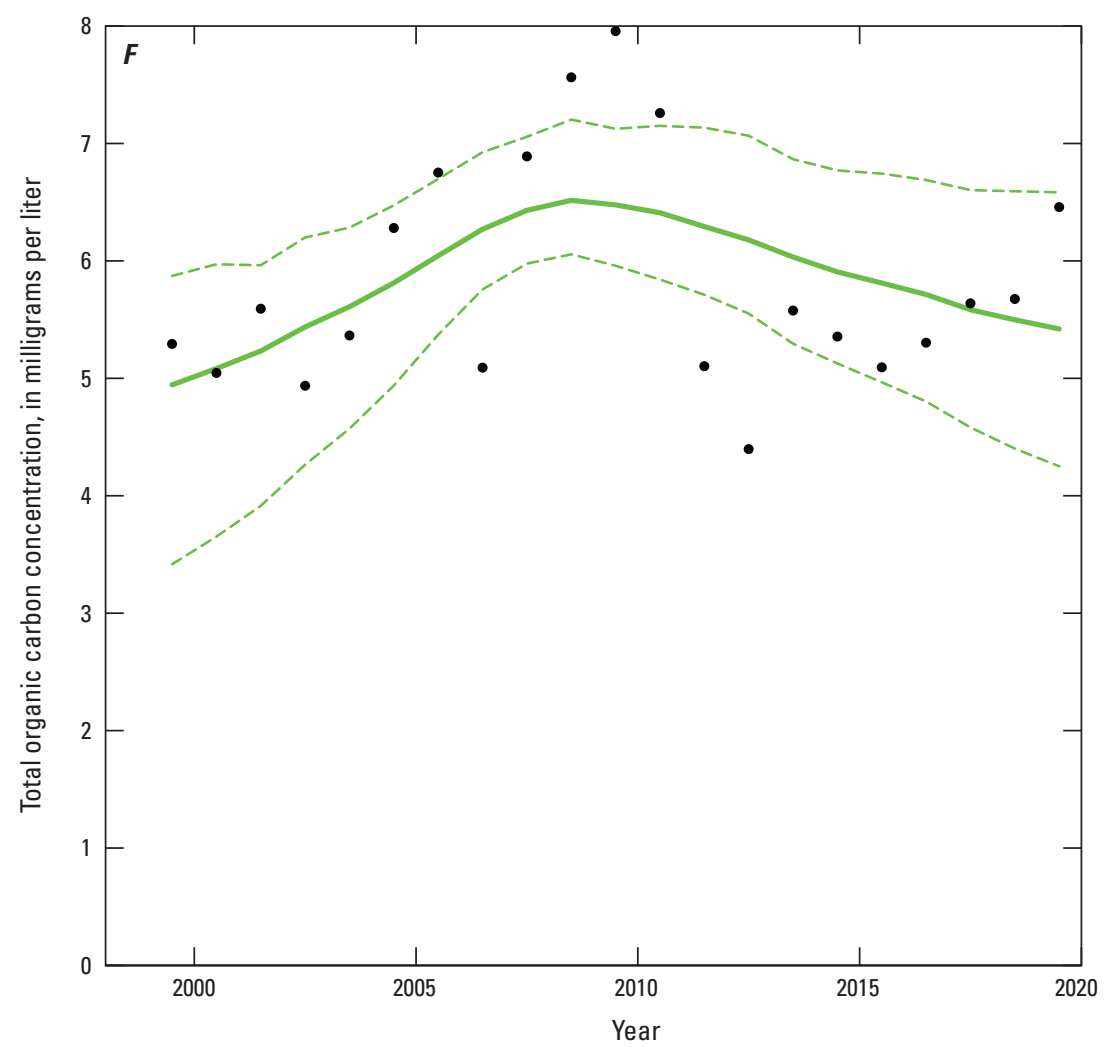

Figure 8. Annual mean concentrations with flow-normalized concentration trend and 90-percent confidence interval for constituents at the North Fork Ninnescah River upstream from Cheney Reservoir (U.S. Geological Survey site 07144780), south-central Kansas, 1999 through 2019. $A$, total suspended solids; $B$, suspended sediment; $C$, nitrate plus nitrite; $D$, orthophosphate; $E$, total phosphorus; $F$, total organic carbon.-Continued 


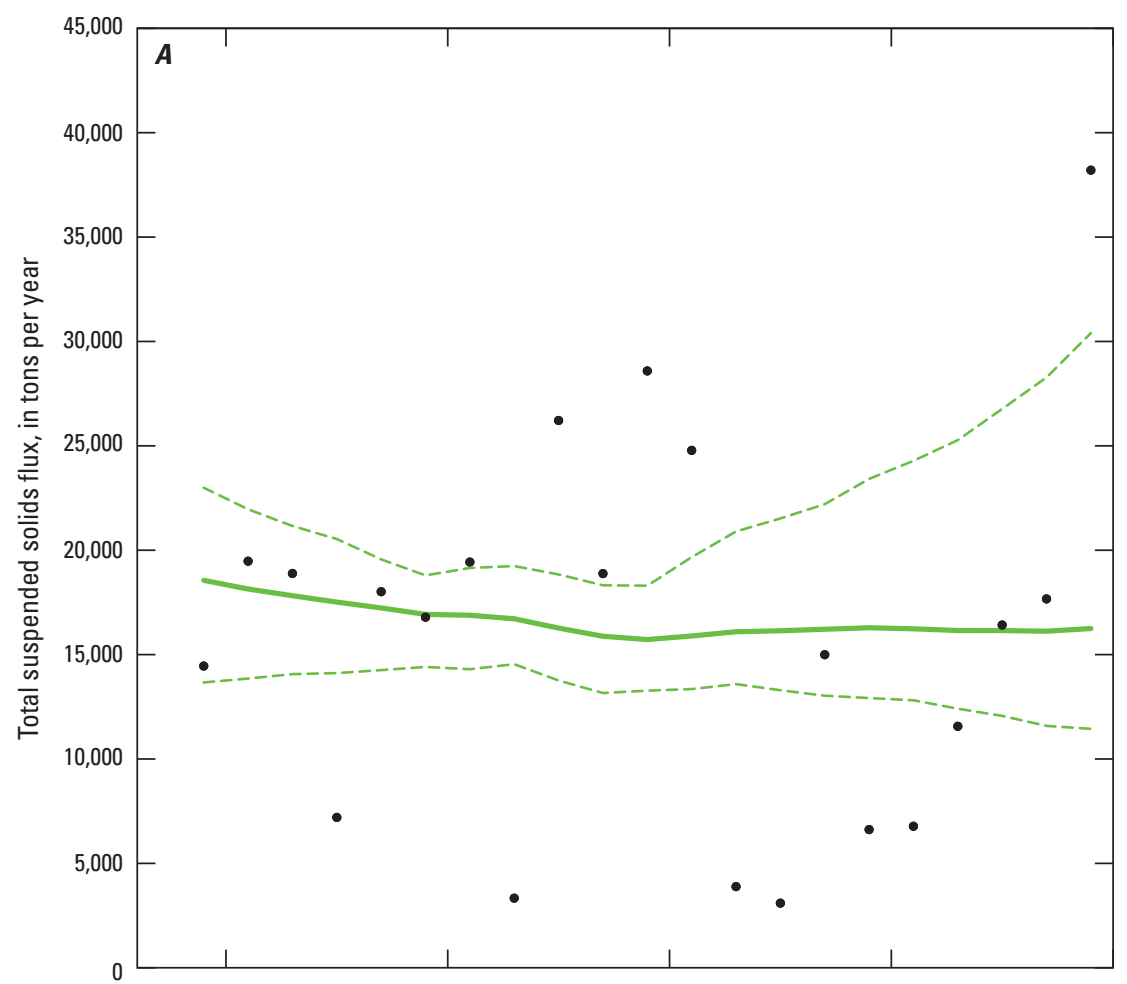

EXPLANATION

Flow-normalized flux

90-percent confidence interval on flow-normalized flux

- Annual mean flux

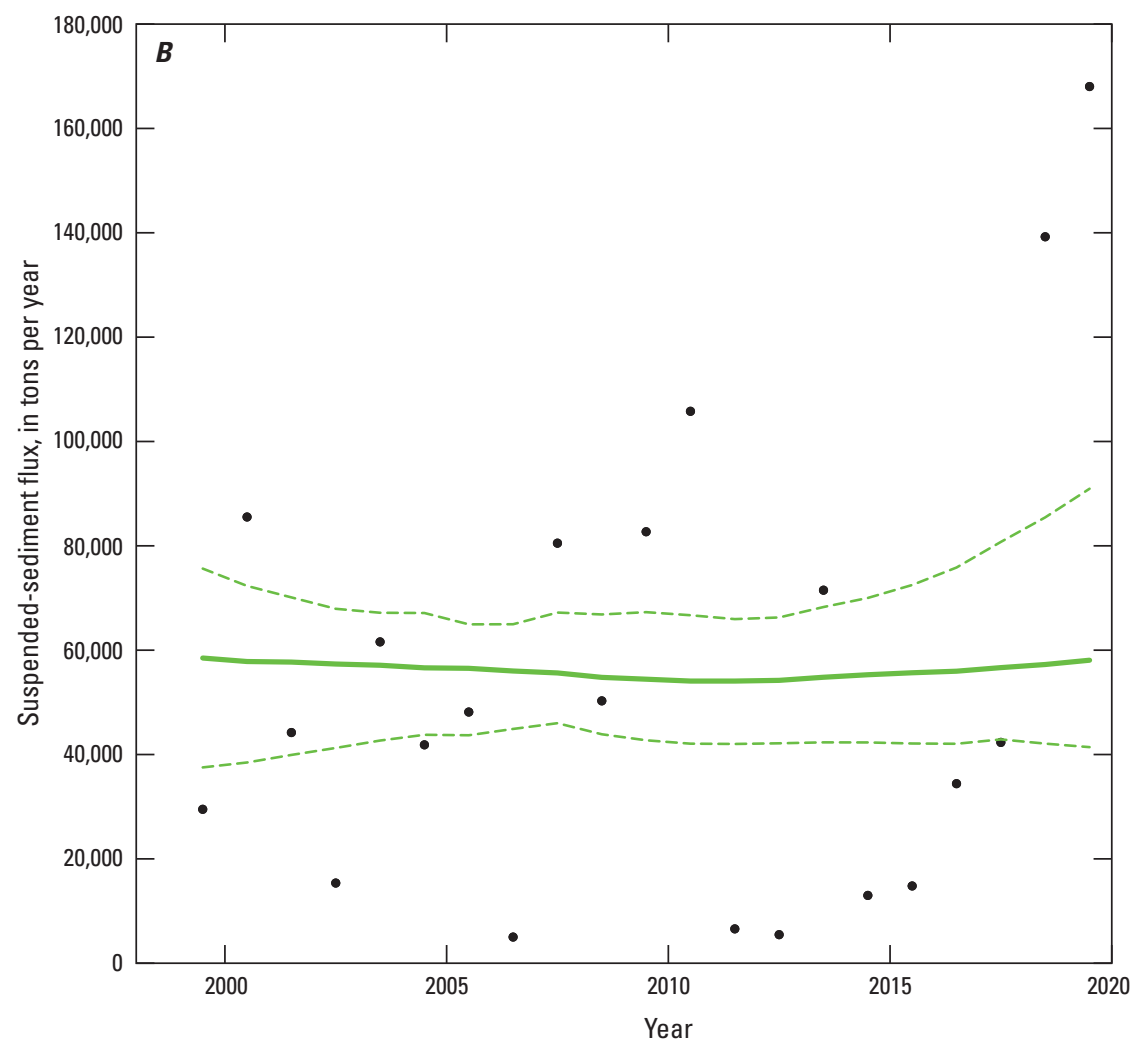

Figure 9. Annual mean fluxes with flow-normalized flux trend and 90-percent confidence interval for constituents at the North Fork Ninnescah River upstream from Cheney Reservoir (U.S. Geological Survey site 07144780), south-central Kansas, 1999 through 2019. $A$, total suspended solids; $B$, suspended sediment; $C$, nitrate plus nitrite; $D$, orthophosphate; $E$, total phosphorus; $F$, total organic carbon. 


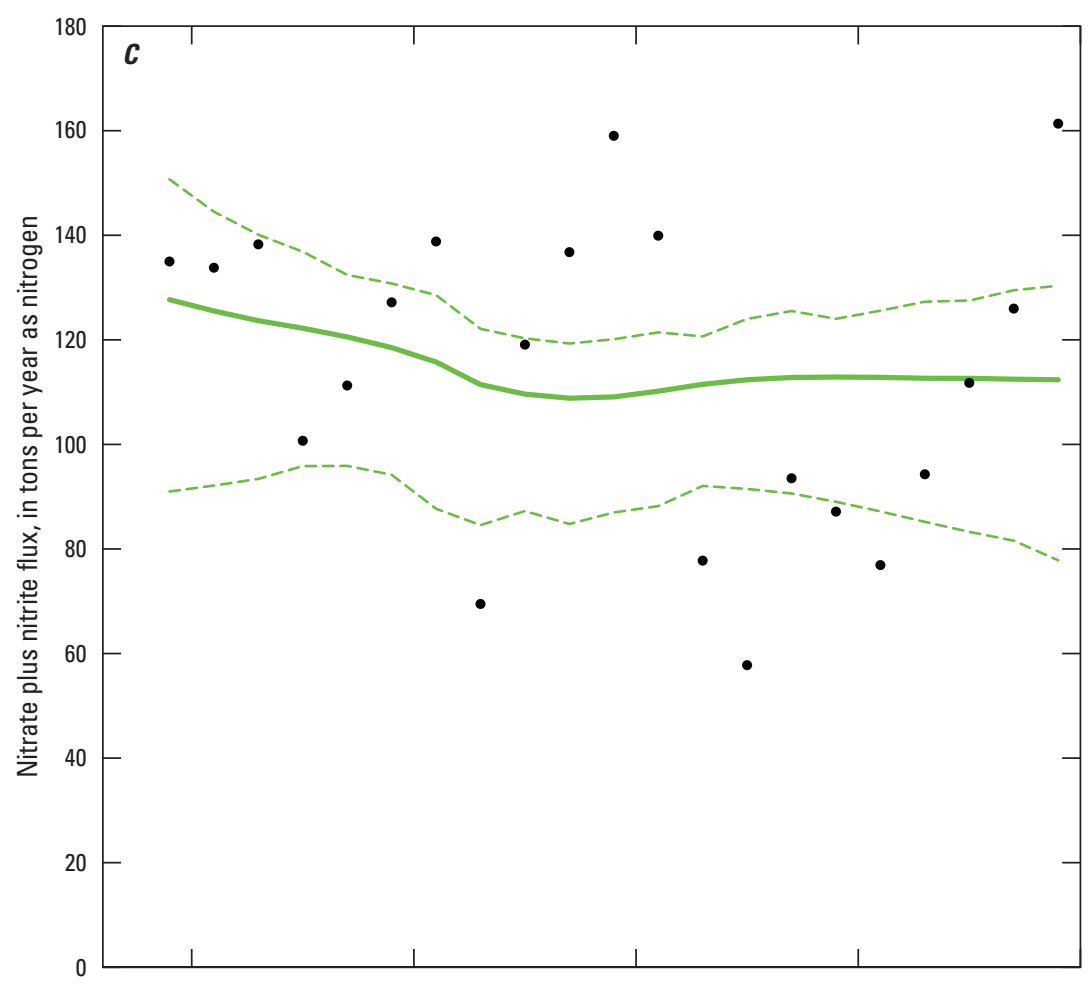

EXPLANATION

Flow-normalized flux

90-percent confidence interval on flow-normalized flux

- $\quad$ Annual mean flux

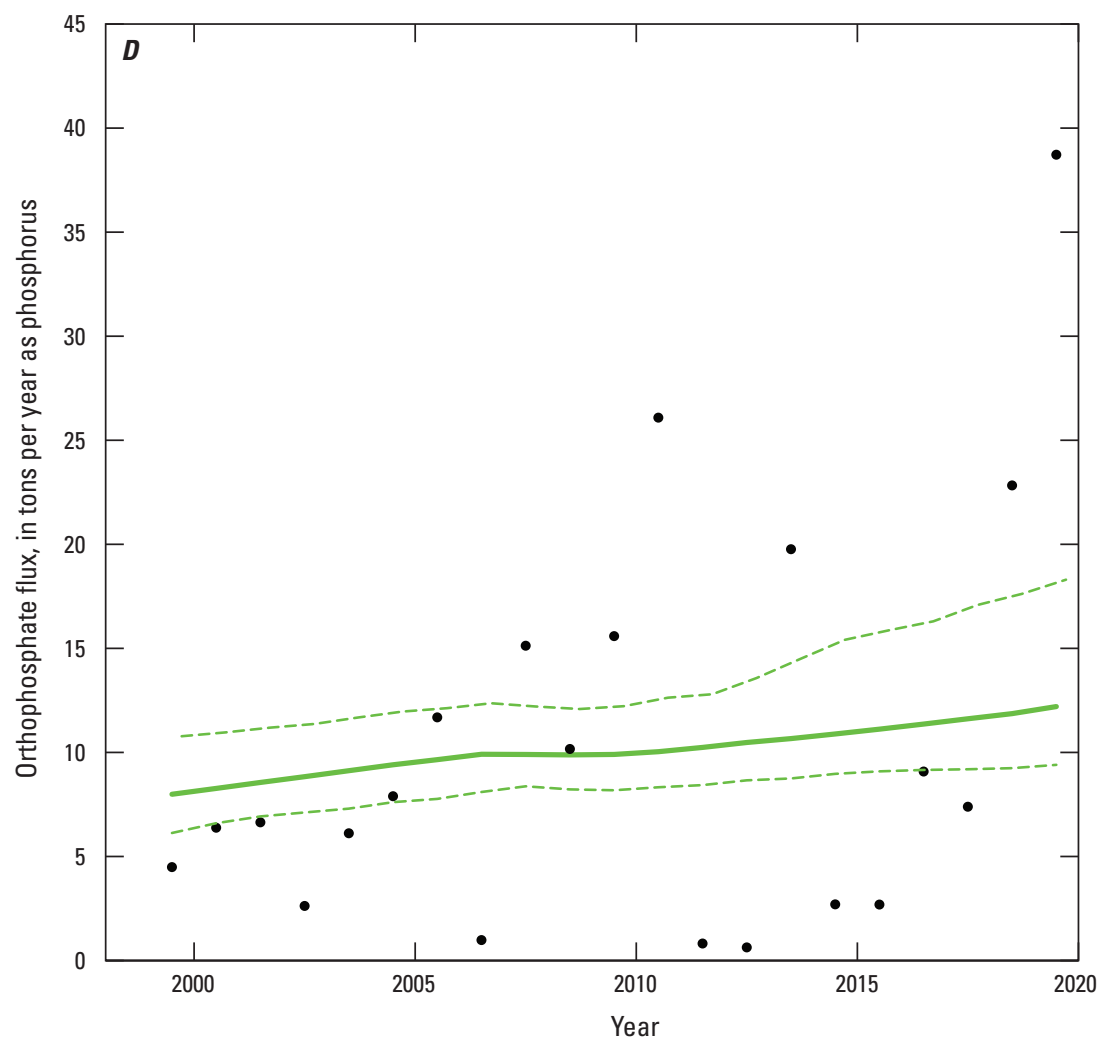

Figure 9. Annual mean fluxes with flow-normalized flux trend and 90-percent confidence interval for constituents at the North Fork Ninnescah River upstream from Cheney Reservoir (U.S. Geological Survey site 07144780), south-central Kansas, 1999 through 2019. $A$, total suspended solids; $B$, suspended sediment; $C$, nitrate plus nitrite; $D$, orthophosphate; $E$, total phosphorus; $F$, total organic carbon.-Continued 


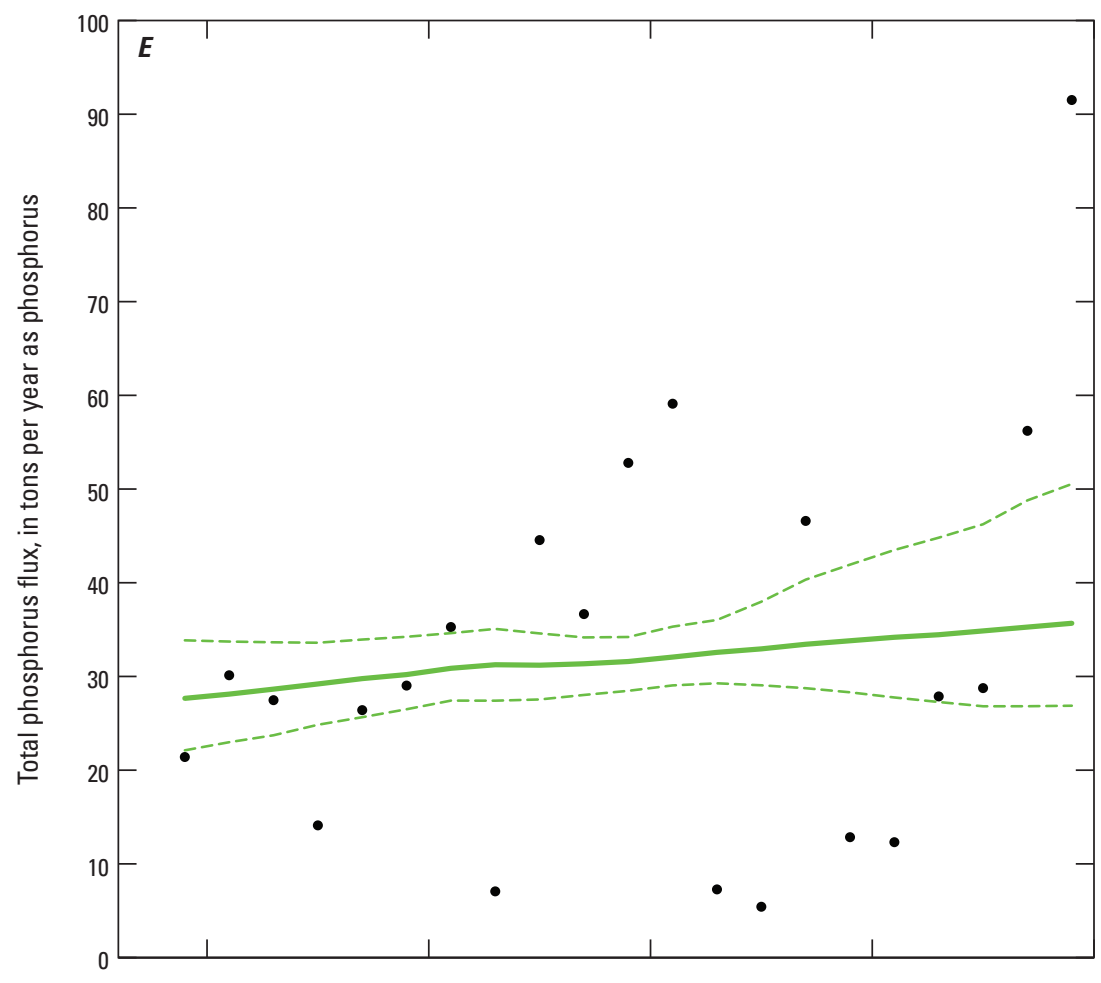

EXPLANATION

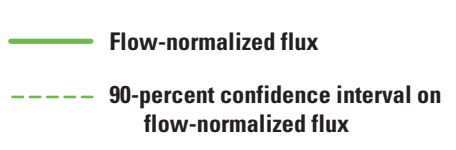

- Annual mean flux

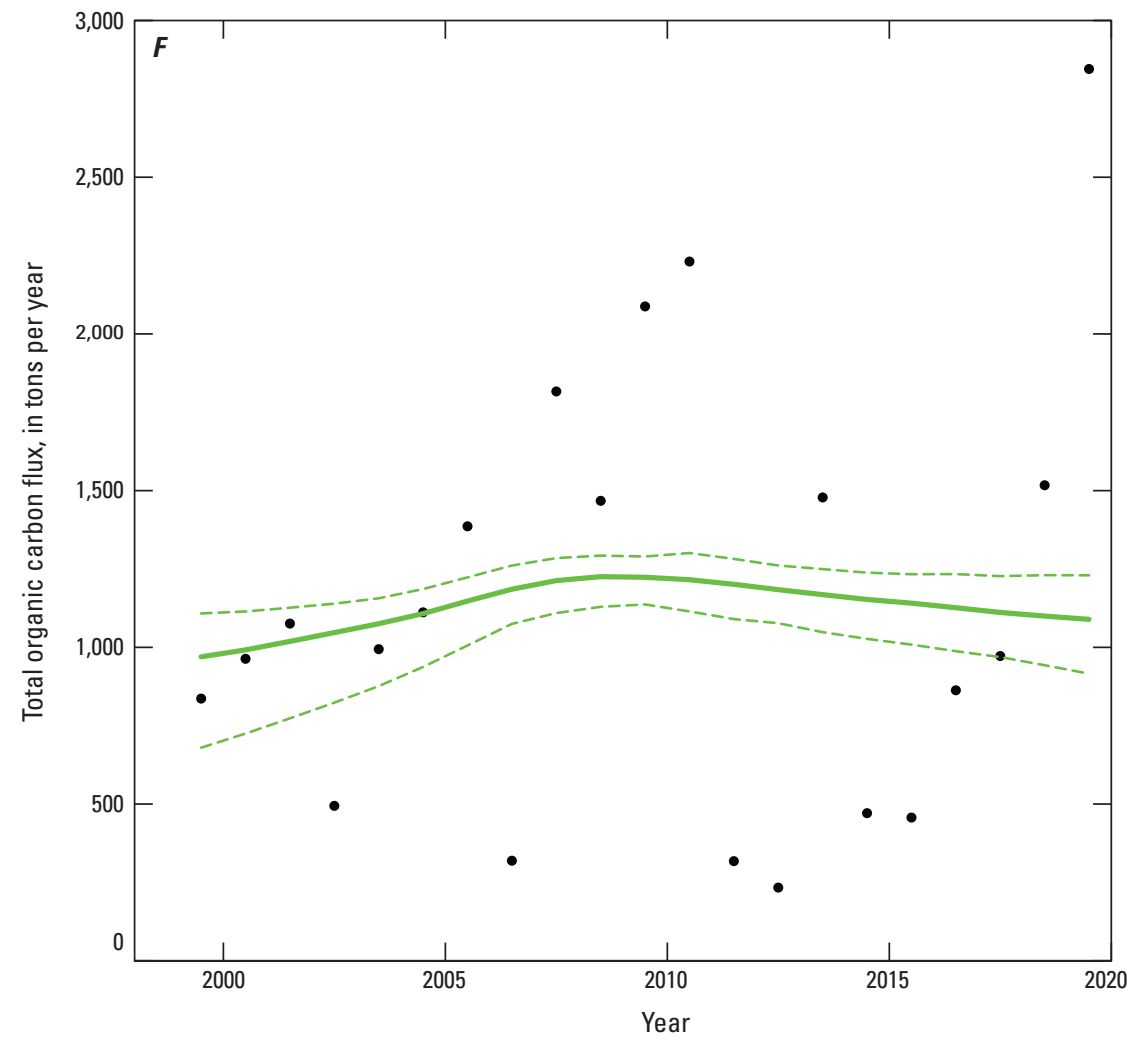

Figure 9. Annual mean fluxes with flow-normalized flux trend and 90-percent confidence interval for constituents at the North Fork Ninnescah River upstream from Cheney Reservoir (U.S. Geological Survey site 07144780), south-central Kansas, 1999 through 2019. $A$, total suspended solids; $B$, suspended sediment; $C$, nitrate plus nitrite; $D$, orthophosphate; $E$, total phosphorus; $F$, total organic carbon.-Continued 
Table 13. Definitions for descriptive statements of likelihood of trends for Weighted Regressions on Time, Discharge, and Season bootstrap test as a function of the posterior mean estimate of the probability of an upward (or downward) trend ( $\hat{\pi}$; Hirsch and others, 2015).

$[\geq$, greater than or equal to; $\leq$, less than or equal to; $<$, less than; $>$, greater than]

\begin{tabular}{ll}
\hline \multicolumn{1}{c}{ Range of $\hat{\pi}$ values } & \multicolumn{1}{c}{ Descriptors } \\
\hline$\geq 0.95$ and $\leq 1.0$ & Highly likely. \\
$\geq 0.90$ and $<0.95$ & Very likely. \\
$\geq 0.66$ and $<0.90$ & Likely. \\
$>0.33$ and $<0.66$ & About as likely as not. \\
$>0.1$ and $\leq 0.33$ & Unlikely. \\
$>0.05$ and $\leq 0.1$ & Very unlikely. \\
$\geq 0$ and $\leq 0.05$ & Highly unlikely. \\
\hline
\end{tabular}

Based on trend descriptors defined by Hirsch and others (2015; table 13), flow-normalized concentrations of TSS, SSC, OP, TP, and TOC had upward trend probabilities during 1999 through 2017 (table 14). Flow-normalized concentrations of nitrate plus nitrite during 1999 through 2017 had a probability of a downward trend (table 14). There was a probability of an upward trend in OP, TP, and TOC flownormalized fluxes (table 14). Flow-normalized TSS and suspended-sediment fluxes had no trend (table 14). There was a probability for a downward trend in flow-normalized nitrate plus nitrite flux (table 14).

TSS (fig. $8 A$ ) and SSC (fig. $8 B$ ) had upward trend probabilities in concentration during 1999 through 2017 and had probabilities of a very likely upward and highly likely upward trend (table 14), respectively. OP (fig. 8D), TP (fig. $8 E$ ), and TOC (fig. $8 F$ ) had probabilities of a highly likely, very likely, and likely upward trend respectively (table 14); however, TP flow-normalized concentrations were similar during 2005 through 2019 (fig. 8E) and TOC decreased after a 2008 peak (fig. 8F). Flow-normalized concentrations of TOC in 2019 were larger than 1999 despite the downward trend. OP flow-normalized concentration (fig. 8D) increased over the study period. Nitrate plus nitrite concentration was the only modeled constituent resulting in a probability of an overall downward trend (table 14). Flownormalized nitrate plus nitrite concentrations decreased during 1999-2009; during 2010-19, flow-normalized concentrations increased by 6 percent (fig. $8 C$; table 11 ).

TSS (fig. 9A) and SSC (fig. 9B) flow-normalized fluxes did not vary substantially over the analysis period and had a trend probability that was equally likely in either direction (table 14). Annual nitrate plus nitrite flow-normalized flux had a likely downward trend probability (fig. 9C). Annual flow-normalized TP flux had a very likely upward trend probability (fig. 9E). The OP flux trend (fig. 9D) is like TP, with a highly likely upward trend probability. Although TOC flow-normalized flux indicated an upward trend probability was likely (table 10), the flow-normalized flux trendline is like the flow-normalized concentration with a peak in flux around 2008 and then a small downward trend through 2019 (fig. 9F).

By examining subsets and the entirety of the analysis period (1999-2009, 2009-19, and 1999-2019) for concentration and flux for each of the modeled constituents (table 15), periods when the trend changed during the analysis period were identified. Nitrate plus nitrite had a negative trend in flow-normalized concentration during 1999 through 2009 and a positive trend in flow-normalized concentration during 2009 through 2019 (table 15). However, for the period of analysis (1999-2019), nitrate plus nitrite had a likely downward trend probability. TOC flow-normalized concentrations had a positive trend during 1999-2009 and a negative trend during 2009-19 with an overall trend probability during 1999-2019 of likely upward (table 15). Flow-normalized flux directional trends for nitrate plus nitrite and TOC were the same as the trends for flow-normalized concentrations. Trend changes in flow-normalized flux for TSS and SSC were negative from 1999 to 2009 and slightly positive from 2009 to 2019, resulting in small downward trends over the period of analysis (table 15).

\section{Comparison of Results with Long-Term Water-Quality Goals}

WBT analysis removes hydrologic variability that can obscure long-term water-quality temporal trends. Flownormalized concentrations for TSS (fig. 8A) were smaller than the CRTF long-term goal of $100 \mathrm{mg} / \mathrm{L}$; however, the upward trend indicates the $100 \mathrm{mg} / \mathrm{L}$ goal may be exceeded unless existing land-use practices change. Nitrate plus nitrite flow-normalized concentrations (fig. 8C) exceeded the $1.2 \mathrm{mg} / \mathrm{L} \mathrm{CRTF}$ goal at the beginning of the analysis period (1999-2003) and then decreased to less than the goal for the remainder of the analysis period. The trend in flownormalized concentrations of nitrate plus nitrite was fairly stable since 2012 but could potentially increase into the future (based on 90-percent confidence intervals) and exceed CRTF long-term goals. Annual flow-normalized TP concentrations (fig. $8 E$ ) were higher than the $0.1 \mathrm{mg} / \mathrm{L} \mathrm{CRTF}$ goal for the entire analysis period in addition to the upward trend. Since 1999, improvements resulting from efforts to decrease TSS and TP concentrations in the drainage basin were not evident. Based on the trends identified and presented as part of this analysis, efforts in the drainage basin, since the formation of the CRTF, to reduce water-quality constituents of concern may not be enough to meet the long-term goals established by the CRTF.

The Cheney Lake TMDL allocation for sediment is a 10 -percent reduction. WBTs did not indicate an upward trend in suspended-sediment flux over the study period (table 14), despite indicating that an upward trend in flow-normalized 
Table 14. Summary of trend likelihood results of Weighted Regressions on Time, Discharge, and Season bootstrap tests for trends in flow-normalized concentrations and fluxes at the North Fork Ninnescah River upstream from Cheney Reservoir (U.S. Geological Survey site 07144780), south-central Kansas, 1999 through September 2017.

[Trends in flow-normalized annual concentrations and fluxes are from Weighted Regressions on Time, Discharge, and Season models; $\uparrow$, upward trend; $\downarrow$, downward trend; --, no trend; $\hat{\pi}$, the posterior mean estimate of the probability of an upward (or downward) trend (Hirsch and others, 2015)]

\begin{tabular}{|c|c|c|c|c|c|c|}
\hline \multirow[b]{2}{*}{ Water-quality constituent } & \multicolumn{3}{|c|}{ Flow-normalized concentration } & \multicolumn{3}{|c|}{ Flow-normalized flux } \\
\hline & $\uparrow / \downarrow$ & $\hat{\pi}$ & Likelihood descriptor & $\uparrow / \downarrow$ & $\hat{\pi}$ & Likelihood descriptor \\
\hline Total suspended solids & $\uparrow$ & 0.912 & Upward trend is very likely & -- & 0.363 & Upward trend is as likely as not. \\
\hline Suspended sediment & $\uparrow$ & 0.988 & Upward trend is highly likely & -- & 0.463 & Upward trend is as likely as not. \\
\hline Nitrate plus nitrite & $\downarrow$ & 0.856 & Downward trend is likely & $\downarrow$ & 0.900 & Downward trend is likely. \\
\hline Orthophosphate & $\uparrow$ & 0.971 & Upward trend is highly likely & $\uparrow$ & 0.990 & Upward trend is highly likely. \\
\hline Total phosphorus & $\uparrow$ & 0.931 & Upward trend is very likely & $\uparrow$ & 0.912 & Upward trend is very likely. \\
\hline Total organic carbon & $\uparrow$ & 0.787 & Upward trend is likely & $\uparrow$ & 0.838 & Upward trend is likely. \\
\hline
\end{tabular}


Table 15. Trend changes for selected water-quality constituents at the North Fork Ninnescah River upstream from Cheney Reservoir (U.S. Geological Survey site 07144780), south-central Kansas, 1999 through 2019.

[Estimated changes in trends are from Weighted Regressions on Time, Discharge, and Season models. Negative trends are shown in bold. \% change, percent flow-normalized concentrations or fluxes changed over the specified period; \%/yr, percent change divided by total number of years during period; mg/L, milligram per liter; yr, year]

\begin{tabular}{|c|c|c|c|c|c|c|c|c|c|c|c|c|c|c|c|c|c|c|}
\hline \multirow[b]{2}{*}{ 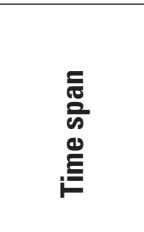 } & \multicolumn{3}{|c|}{ Total suspended solids } & \multicolumn{3}{|c|}{ Suspended sediment } & \multicolumn{3}{|c|}{ Nitrate plus nitrite } & \multicolumn{3}{|c|}{ Orthophosphate } & \multicolumn{3}{|c|}{ Total phosphorus } & \multicolumn{3}{|c|}{ Total organic carbon } \\
\hline & 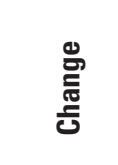 & 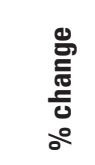 & $\begin{array}{l}\stackrel{2}{a} \\
\text { ¿ } \\
\text { 흥 }\end{array}$ & 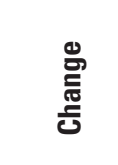 & 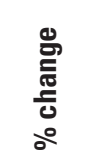 & $\begin{array}{l}\stackrel{2}{\vdots} \\
\vdots \\
\frac{0}{0}\end{array}$ & 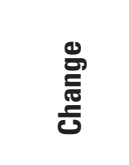 & 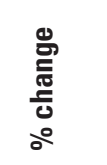 & 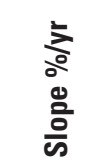 & $\begin{array}{l}\text { 을 } \\
\text { 苞 }\end{array}$ & 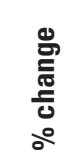 & $\begin{array}{l}\stackrel{2}{a} \\
\text { ¿ } \\
\text { 흥 }\end{array}$ & $\begin{array}{l}\stackrel{0}{E} \\
\frac{\bar{E}}{0}\end{array}$ & 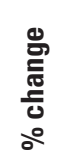 & 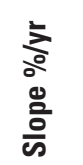 & $\begin{array}{l}\text { 可 } \\
\text { 壱 }\end{array}$ & 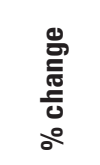 & 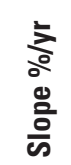 \\
\hline \multicolumn{19}{|c|}{ Flow-normalized concentration trends (mg/L) } \\
\hline 1999-2009 & 4 & 6.3 & 0.6 & 17 & 15 & 1.5 & -0.29 & -22 & -2.2 & 0.008 & 47 & 4.7 & 0.02 & 20 & 2.0 & 1.5 & 31 & 3.1 \\
\hline 2009-19 & 16 & 23 & 2.3 & 61 & 47 & 4.7 & 0.078 & 7.4 & 0.74 & 0.003 & 12 & 1.2 & 0.01 & 5.1 & 0.51 & -1.1 & -16 & -1.6 \\
\hline 1999-2019 & 20 & 31 & 1.5 & 78 & 68 & 3.4 & -0.21 & -16 & -0.8 & 0.011 & 64 & 3.2 & 0.03 & 26 & 1.3 & 0.5 & 9.6 & 0.5 \\
\hline \multicolumn{19}{|c|}{ Flow-normalized flux trends (tons/yr) } \\
\hline 1999-2009 & $-2,840$ & -15 & -1.5 & $-4,050$ & -6.9 & -0.69 & -19 & -15 & -1.5 & 1.9 & 24 & 2.4 & 3.9 & 14 & 1.4 & 254 & 26 & 2.6 \\
\hline 2009-19 & 528 & 3.4 & 0.34 & 3,640 & 6.7 & 0.67 & 3.3 & 3.0 & 0.3 & 2.3 & 23 & 2.3 & 4.1 & 13 & 1.3 & -134 & -11 & -1.1 \\
\hline 1999-2019 & $-2,310$ & -12 & -0.62 & -414 & -0.71 & -0.04 & -15 & -12 & -0.6 & 4.2 & 53 & 2.6 & 8.0 & 29 & 1.4 & 120 & 12 & 0.6 \\
\hline
\end{tabular}


SSC was highly likely (table 14). The phase II Cheney Lake TMDL for TP $(40,184$ pounds per year-about 20 tons per year; Kansas Department of Health and Environment, $2015 b$ ) was exceeded in 14 out of 20 years of this study by 5 (in 2016) to 190 (in 2010) percent (table 9). Additionally, WBTs indicate that TP flow-normalized loads are very likely increasing (table 14).

Effects of agricultural BMPs on stream water quality are highly variable (Sprague and others, 2011; Kroll and Oakland, 2019; Oelsner and Stets, 2019). Linking water-quality changes to causal factors requires consistent monitoring before, during, and after changes; this presents challenges related to length and frequency of data collection and available concomitant land-use and conservation practice data. A complete concomitant long-term dataset of specific BMP types and locations is not available for the State of Kansas, including the Cheney Reservoir drainage basin. As such, attribution of water-quality trends to land-use changes or conservation practices was not possible for this study. Further, detection of BMP implementation effects may not be possible at the basin scale. Additionally, because precipitation frequency and intensity are projected to continue to increase in the Great Plains region (Shafer and others, 2014; Kloesel and others, 2018), accounting for extreme episodic events may be an important consideration for future sediment and nutrient load reduction plans.

\section{Summary}

The North Fork Ninnescah River, in south-central Kansas, is the largest tributary into Cheney Reservoir and contributes about 70 percent of the inflow. Cheney Reservoir is the primary drinking-water source for the city of Wichita, providing about 70 percent of the municipal water supply. Concerns about taste-and-odor issues and cyanobacterial blooms causing public health concerns, displeasing drinking water, and increased treatment costs led to the formation of the Cheney Reservoir Task Force (CRTF) in 1992. The CRTF identified nutrients and sediments as primary pollutants of concern in the Cheney Reservoir watershed and prepared a water-quality plan to abate the transport of these pollutants.

Since November 1998, the U.S. Geological Survey, in cooperation with the City of Wichita, has been monitoring water quality on the North Fork Ninnescah River upstream from Cheney Reservoir (U.S. Geological Survey site 07144780) (that is, the "inflow site") to better describe changing conditions in the drainage basin. Continuous water-quality data collection of physical properties (water temperature, specific conductance, $\mathrm{pH}$, dissolved oxygen, and turbidity) in combination with discretely collected samples has provided necessary information to develop site-specific regression models to describe water-quality conditions that cannot be continuously monitored. Linear regression models including total suspended solids (TSS), suspended-sediment concentration (SSC), nitrate plus nitrite, nitrate, orthophosphate (OP), total phosphorus (TP), and total organic carbon (TOC) were updated from previous studies published in 2006 and 2013. Additional data collection over a wider range of hydrologic conditions and changing continuous data collection technology facilitated the development of new models.

Continuous streamflow, water temperature, specific conductance, $\mathrm{pH}$, dissolved-oxygen, and turbidity data were collected at the inflow site during November 1998 through 2019. Daily mean streamflow ranged from 0 to 8,250 cubic feet per second $\left(\mathrm{ft}^{3} / \mathrm{s}\right)$ with a mean annual streamflow of $128 \mathrm{ft} 3 / \mathrm{s}$ during 1999 through 2019. The 10-percent streamflow-separation point used to define base-flow and runoff conditions occurred at $190 \mathrm{ft} 3 / \mathrm{s}$. The largest annual streamflow occurred during 2019 , and the smallest annual streamflow occurred during 2012. The $\mathrm{pH}$ values never dropped to less than the Kansas aquatic-life-support criterion of 6.5 standard units, but they did exceed 8.5 standard units about 28 percent of the time during 1999 through 2019. Dissolved-oxygen concentrations were less than the Kansas aquatic-life-support criterion of 5 milligrams per liter $(\mathrm{mg} / \mathrm{L})$ less than 1 percent of the time. Turbidity exceeded the U.S. Environmental Protection Agency nonenforceable guideline for level III ecoregion 27 streams of 22.13 formazin nephelometric units about 37 percent of the time.

Daily concentrations, loads, and yields were computed for all modeled constituents included in this report during 1999 through 2019. TSS and SSC had the largest loads during 2010. The corresponding streamflow total in 2010 was the second highest during the period of analysis. The largest annual streamflow was in 2019, yet TSS and suspended-sediment loads were noticeably smaller than in 2010 (second largest annual streamflow). Limitations with the available turbidity data for TSS model development likely played a role in the smaller computed loads in 2019. The low bias potential should be considered when interpreting the results of the models using turbidity as a surrogate. The smallest loads for TSS and SSC were during 2011 (year with the second smallest annual streamflow).

Sedimentation is progressively reducing the storage capacity of Cheney Reservoir. During 1999-2019, 55 percent of the suspended-sediment load was transported during the top 1 percent of loading days ( 76 days); 22 percent of the total load during 1999-2019 was transported in the top 10 loading days. The data continue to indicate substantial parts of suspended-sediment loads are delivered during disproportionately small periods. Successful sediment management efforts necessitate reduction techniques that account for these large load events.

Nitrate plus nitrite and nitrate annual loads were largest in 2018 despite it having the fourth largest annual streamflow. During October through December 2018, about 65 percent of total annual nitrate plus nitrite and nitrate loads were transported. The total streamflow in October through December 2018 was on average 7 times larger (range: 2.8-22.5 times larger) than the total streamflow during this 
period of any other year during the analysis period. It is likely agricultural practices, including fertilizer application, contributed to the elevated nitrate plus nitrite and nitrate loads computed at the inflow site during greater than average precipitation events during October through December 2018. OP, TP, and TOC loads were largest in 2010 and 2019 (years with highest annual streamflow) and smallest in 2011 and 2012 (years with smallest annual streamflow).

CRTF goals for base-flow concentrations of TSS, nitrate plus nitrite, and TP were exceeded more frequently (70 to 99.9 percent of the time) than runoff goals ( 0 to 11 percent of the time). Except for 2012, annual mean TSS concentrations exceeded the base-flow goal every year. Annual mean concentrations of nitrate plus nitrite and TP exceeded the base-flow goals every year. Except for 2000 and 2011-12, annual mean nitrate plus nitrite concentrations were larger during baseflow conditions than during runoff conditions and exceeded base-flow goals by 3.5-4.5 times, indicating goals may not be attainable. Annual mean concentrations of TSS and nitrate plus nitrite during runoff conditions never exceeded the CRTF runoff goal, and TP annual mean concentrations during runoff conditions only exceeded the CRTF runoff goal during 2002.

North Fork Ninnescah River sediment and nutrient temporal trends have not been evident largely because of hydrologic variability. Weighted Regressions on Time, Discharge, and Season (WRTDS) can be used to estimate annual or seasonal mean water-quality constituent concentrations and fluxes and to describe long-term water-quality constituent trends. Flow-based flux computations using WRTDS models for TSS, SSC, nitrate plus nitrite, OP, TP, and TOC during 1999 through 2019 had mean relative percentage differences ranging from -3 to 25 percent from the loads computed using linear regression models. Total computed flux from the flow-based models was generally greater than flux from the loads computed using linear regression models except for OP and TOC, which were slightly lower over the analysis period.

Flow-normalized concentrations and fluxes were computed using WRTDS statistical models and trends were described using WRTDS bootstrap tests. Flow-normalized concentrations of TSS, SSC, OP, TP, and TOC had upward trend probabilities. A downward trend was identified in nitrate plus nitrite flow-normalized concentrations. There was a probability of an upward trend in OP, TP, and TOC flow-normalized fluxes. No trends were identified for flownormalized flux of TSS or SSC during the study. Nitrate plus nitrite flow-normalized flux indicated a downward trend.

Flow-normalized concentrations for TSS were less than the CRTF long-term goal of $100 \mathrm{mg} / \mathrm{L}$, but the upward trend for TSS indicated the long-term goal could be exceeded if no changes are made. The Cheney Lake total maximum daily load allocation for sediment is a 10-percent reduction. WRTDS bootstrap tests did not indicate an upward trend in suspended-sediment flow-normalized flux over the study period, despite indicating that an upward trend in flownormalized SSC was highly likely.
Flow-normalized TP concentrations were larger than the CRTF long-term goal of $0.1 \mathrm{mg} / \mathrm{L}$ for the period of analysis. The phase II Cheney Lake total maximum daily load for TP was exceeded in 14 out of 20 years of this study by 5 (in 2016) to 190 (in 2010) percent. Additionally, WRTDS bootstrap tests indicate that TP flow-normalized loads are very likely increasing.

Flow-normalized concentrations of nitrate plus nitrite exceeded the CRTF long-term goal of $1.2 \mathrm{mg} / \mathrm{L}$ during 1999-2003 and then decreased to less than the goal for the remainder of the analysis period (2004-19). Flow-normalized nitrate plus nitrite concentrations decreased during 1999-2009; during 2010-19, flow-normalized concentrations increased by 6 percent. Based on the trends identified and presented as part of this analysis, current efforts to reduce water-quality constituents of concern may not be enough to meet the long-term goals established by the CRTF.

Continued data collection would be beneficial to update and describe changing water-quality conditions in the drainage basin and in the reservoir over time. Long-term water-quality data collection (20+ years) makes it possible to analyze trends of flow-normalized data because this type of statistical analysis requires a robust and lengthy dataset. Linking water-quality changes to causal factors requires consistent monitoring before, during, and after changes; this presents challenges related to length and frequency of data collection and available concomitant land-use and conservation practice data. A complete concomitant long-term dataset of specific best management practice types and locations is not available for the State of Kansas, including the Cheney Reservoir drainage basin. As such, attribution of water-quality trends to land-use changes or conservation practices was not possible for this study. Additionally, because precipitation frequency and intensity are projected to continue to increase in the Great Plains region, accounting for extreme episodic events may be an important consideration for future sediment and nutrient load reduction plans. The information in this report allows the City of Wichita to base decisions regarding the municipal water supply in Cheney Reservoir on past and present water-quality conditions and trends in the drainage basin.

\section{References Cited}

Agel, L., Barlow, M., Colby, F., Binder, H., Catto, J.L., Hoell, A., and Cohen, J., 2019, Dynamical analysis of extreme precipitation in the US northeast based on large-scale meteorological patterns: Climate Dynamics, v. 52, no. 3-4, p. 1739-1760. [Also available at https://doi.org/10.1007/ s00382-018-4223-2.]

Agel, L., Barlow, M., Feldstein, S.B., and Gutowski, W.J., Jr., 2018, Identification of large-scale meteorological patterns associated with extreme precipitation in the US northeast: Climate Dynamics, v. 50, no. 5-6, p. 1819-1839. [Also available at https://doi.org/10.1007/s00382-017-3724-8.] 
Allan, J.D., and Castillo, M.M., 2007, Stream ecologyStructure and function of running waters ( $2 \mathrm{~d}$ ed.): Dordrecht, Netherlands, Springer, 436 p.

American Public Health Association, American Water Works Association, and Water Environment Federation, 1995, Standard methods for the examination of water and wastewater (19th ed.): Washington, D.C., American Public Health Association, $905 \mathrm{p}$.

Anderson, C.W., 2005, Turbidity (ver. 2.1, September 2005): U.S. Geological Survey Techniques of Water-Resources Investigations, book 9, chap. A6.7, 55 p. [Also available at https://doi.org/10.3133/twri09A6.7.]

ASTM International, 2003, D1889-00 Standard test method for turbidity of water, in ASTM International, Annual Book of ASTM Standards: West Conshohocken, Penn., Water and Environmental Technology, 6 p.

Barlow, M., Gutowski, W.J., Jr., Gyakum, J.R., Katz, R.W., Lim, Y.-K., Schumacher, R.S., Wehner, M.F., Agel, L., Bosilovich, M., Collow, A., Gershunov, A., Grotjahn, R., Leung, R., Milrad, S., and Min, S.-K., 2019, North American extreme precipitation events and related largescale meteorological patterns - A review of statistical methods, dynamics, modeling, and trends: Climate Dynamics, v. 53, no. 11, p. 6835-6875. [Also available at https://doi.org/10.1007/s00382-019-04958-z.]

Bennett, T.J., Graham, J.L., Foster, G.M., Stone, M.L., Juracek, K.E., Rasmussen, T.J., and Putnam, J.E., 2014, U.S. Geological Survey quality-assurance plan for continuous water-quality monitoring in Kansas, 2014: U.S. Geological Survey Open-File Report 2014-1151, 34 p. plus appendixes, accessed January 2020 at https://doi.org/ 10.3133/ofr20141151.

Bureau of Reclamation, 2016, Wichita project: Bureau of Reclamation web page, accessed October 2019 at https:/www.usbr.gov/projects/index.php?id=403.

Camargo, J.A., and Alonso, Á., 2006, Ecological and toxicological effects of inorganic nitrogen pollution in aquatic ecosystems - A global assessment: Environment International, v. 32, no. 6, p. 831-849. [Also available at https://doi.org/10.1016/j.envint.2006.05.002.]

Cheney Reservoir Task Force, 1994, Watershed pollution management plan for North Fork Ninnescah Watershed and Cheney Reservoir: Final Report: 22 p.

Christensen, V.G., Graham, J.L., Milligan, C.R., Pope, L.M., and Ziegler, A.C., 2006, Water quality and relation to tasteand-odor compounds in the North Fork Ninnescah River and Cheney Reservoir, south-central Kansas, 1997-2003: U.S. Geological Survey Scientific Investigations Report 2006-5095, 43 p. [Also available at https://doi.org/10.3133/ sir20065095.]
Christensen, V.G., and Pope, L.M., 1997, Occurrence of dissolved solids, nutrients, atrazine, and fecal coliform bacteria during low flow in the Cheney Reservoir watershed, south-central Kansas, 1996: U.S. Geological Survey WaterResources Investigations Report 97-4153, 13 p. [Also available at https://doi.org/10.3133/wri974153.]

Cohen, A.C., Jr., 1950, Estimating the mean and variance of normal populations from singly truncated and doubly truncated samples: Annals of Mathematical Statistics, v. 21, no. 4, p. 557-569, accessed October 2019 at https://doi.org/ 10.1214/aoms/1177729751.

Dodge, D.A., Hoffman, B.R., and Horsch, M.L., 1978, Soil survey of Stafford County, Kansas: Washington, D.C., U.S. Government Printing Office, 59 p.

Duan, N., 1983, Smearing estimate-A nonparametric retransformation method: Journal of the American Statistical Association, v. 78, no. 383, p. 605-610. [Also available at https://doi.org/10.1080/01621459.1983.10478017.]

Dubrovsky, N.M., Burrow, K.R., Clark, G.M., Gronberg, J.M., Hamilton, P.A., Hitt, K.J., Mueller, D.K., Munn, M.D., Nolan, B.T., Puckett, L.J., Rupert, M.G., Short, T.M., Spahr, N.E., Sprague, L.A., and Wilber, W.G., 2010, The quality of our Nation's waters - Nutrients in the Nation's streams and groundwater, 1992-2004: U.S. Geological Survey Circular 1350, 174 p. [Also available at https://doi.org/10.3133/ cir1350.]

Fishman, M.J., and Friedman, L.C., 1989, Methods for determination of inorganic substances in water and fluvial sediments ( $3 \mathrm{~d}$ ed.): U.S. Geological Survey Techniques of Water Resources Investigations, book 5, chap. A1, 545 p. [Also available at https://doi.org/10.3133/twri05A1.]

Gillespie, J.B., and Hargadine, G.D., 1994, Geohydrology and saline ground-water discharge to the South Fork Ninnescah River in Pratt and Kingman Counties, south-central Kansas: U.S. Geological Survey Water-Resources Investigations Report 93-4177, 51 p. [Also available at https://doi.org/ 10.3133/wri934177.]

Graham, J.L., Foster, G.M., Williams, T.J., Kramer, A.R., and Harris, T.D., 2017, Occurrence of cyanobacteria, microcystin, and taste-and-odor compounds in Cheney Reservoir, Kansas, 2001-16: U.S. Geological Survey Scientific Investigations Report 2017-5016, 57 p., accessed July 2020 at https://doi.org/10.3133/sir20175016.

Graham, J.L., Loftin, K.A., Ziegler, A.C., and Meyer, M.T., 2008, Cyanobacteria in lakes and reservoirsToxin and taste-and-odor sampling guidelines (ver. 1.0, September 2008): U.S. Geological Survey Techniques of Water-Resources Investigations, book 9, chap. A7, sec. 7.5, accessed September 2016 at https://doi.org/10.3133/ twri09A7.5. 
Graham, J.L., Stone, M.L., Rasmussen, T.J., and Poulton, B.C., 2010, Effects of wastewater effluent discharge and treatment facility upgrades on environmental and biological conditions of the upper Blue River, Johnson County, Kansas and Jackson County, Missouri, January 2003 through March 2009: U.S. Geological Survey Scientific Investigations Report 2010-5248, 85 p. [Also available at https://doi.org/10.3133/sir20105248.]

Gray, J.R., Glysson, G.D., Turcios, L.M., and Schwarz, G.E., 2000, Comparability of suspended-sediment concentration and total suspended solids data: U.S. Geological Survey Water-Resources Investigations Report 2000-4191, 14 p., accessed March 2008 at https://doi.org/10.3133/wri004191.

Guy, H.P., 1969, Laboratory theory and methods for sediment analysis: U.S. Geological Survey Techniques of WaterResources Investigations, book 5, chap. C1, 58 p. [Also available at https://doi.org/10.3133/twri05C1.]

Hald, A., 1949, Maximum likelihood estimation of the parameters of a normal distribution which is truncated at a known point: Scandinavian Actuarial Journal, v. 1949, no. 1, p. 119-134. [Also available at https://doi.org/10.1080/ 03461238.1949.10419767.]

Hansen, C.V., Whisnant, J.A., and Lanning-Rush, J.L., 2014, Status of groundwater levels and storage volume in the Equus Beds aquifer near Wichita, Kansas, 2012 to 2014: U.S. Geological Survey Scientific Investigations Report 2014-5185, 39 p., accessed February 2020 at https://doi.org/ $10.3133 /$ sir20145185.

Helsel, D.R., 2012, Statistics for censored environmental data using Minitab and R: New York, Wiley, 324 p.

Helsel, D.R., and Cohn, T.A., 1988, Estimation of descriptive statistics for multiply censored water quality data: Water Resources Research, v. 24, no. 12, p. 1997-2004. [Also available at https://doi.org/10.1029/WR024i012p01997.]

Helsel, D.R., Hirsch, R.M., Ryberg, K.R., Archfield, S.A., and Gilroy, E.J., 2020, Statistical methods in water resources: U.S. Geological Survey Techniques and Methods, book 4, chapter A3, 458 p. [Also available at https://doi.org/ $10.3133 / \mathrm{tm} 4 \mathrm{a} 3$.] [Supersedes USGS Techniques of WaterResources Investigations, book 4, chapter A3, version 1.1.]

Hem, J.D., 1985, Study and interpretation of chemical characteristics of natural water (3d ed.): U.S. Geological Survey Water-Supply Paper 2254, 263 p., 4 pls. [Also available at https://doi.org/10.3133/wsp2254.]

Hickman, R.E., and Hirsch, R.M., 2017, Trends in the quality of water in New Jersey streams, water years 1971-2011: U.S. Geological Survey Scientific Investigations Report 2016-5176, 58 p., accessed December 2019 at https://doi.org/10.3133/sir20165176.
Hirsch, R.M., Archfield, S.A., and De Cicco, L.A., 2015, A bootstrap method for estimating uncertainty of water quality trends: Environmental Modelling \& Software, v. 73, p. 148-166. [Also available at https://doi.org/10.1016/ j.envsoft.2015.07.017.]

Hirsch, R.M., and De Cicco, L.A., 2015, User guide to Exploration and Graphics for RivEr Trends (EGRET) and dataRetrieval — R packages for hydrologic data (ver. 2.0, February 2015): U.S. Geological Survey Techniques and Methods, book 4, chap. A10, 93 p., accessed December 2019 at https://doi.org/10.3133/tm4A10.

Hirsch, R.M., Moyer, D.L., and Archfield, S.A., 2010, Weighted regressions on time, discharge, and season (WRTDS), with an application to Chesapeake Bay River inputs: Journal of the American Water Resources Association, v. 46, no. 5, p. 857-880, accessed August 23, 2013, at https://doi.org/10.1111/j.1752-1688.2010.00482.x.

Horsch, M.L., Hoffman, B.R., and Gier, D.A., 1968, Soil survey of Pratt County, Kansas: Washington, D.C., U.S. Government Printing Office, $56 \mathrm{p}$.

Juracek, K.E., and Rasmussen, P.P., 2008, Sediment quality and comparison to historical water quality, Little Arkansas River Basin, south-central Kansas, 2007: U.S. Geological Survey Scientific Investigations Report 2008-5187, 47 p., accessed June 2020 at https://doi.org/10.3133/sir20085187.

Kansas Biological Survey, 2012, Bathymetric and sediment survey of Cheney Reservoir, Reno-KingmanSedgwick Counties, Kansas: Kansas Biological Survey Report 2011-01, 54 p. [Also available at https://kgi.contentdm.oclc.org/digital/collection/ p16884coll78/id/64/.]

Kansas Department of Health and Environment, 2000, Lower Arkansas River Basin total maximum daily load: Kansas Department of Health and Environment, Bureau of Water, 9 p., accessed April 2020 at https://www.kdheks.gov/tmdl/la/ CheneySILT.pdf.

Kansas Department of Health and Environment, 2004, Surface water nutrient reduction plan: Topeka, Kans., Kansas Department of Health and Environment, Bureau of Water, 47 p., accessed April 2020 at https://cdm16884.contentdm.oclc.org/digital/collection/ p16884coll4/id/88.

Kansas Department of Health and Environment, 2011, Cheney Lake WRAPS - 9 element watershed plan summary: Kansas Department of Health and Environment, Bureau of Water, 126 p., accessed November 2020 at https://www.kdheks.gov/nps/wraps/CheneyLake_ Plan\&Summary.pdf. 
Kansas Department of Health and Environment, 2015a, Kansas surface water quality standards - Tables of numeric criteria: Kansas Department of Health and Environment, Bureau of Water, 24 p., accessed November 2019 at https://www.kdheks.gov/tmdl/download/SWQS_Tables_ 2015.pdf.

Kansas Department of Health and Environment, 2015b, Lower Arkansas River Basin total maximum daily load: Kansas Department of Health and Environment, 62 p., accessed November 2019 at https:/www.kdheks.gov/tmdl/2015/ Cheney_Eu.pdf.

Kansas Department of Health and Environment, 2016, Historical HABs: Kansas Department of Health and Environment web page, accessed November 2019 at https://www.kdheks.gov/algae-illness/historical_habs.htm.

Kansas Department of Health and Environment, 2018, 2018 303(d) list of all impaired \& potentially impaired waters: Kansas Department of Health and Environment, 56 p., accessed September 2019 at https:/www.kdheks.gov/tmdl/ 2018/Approved_2018_303_d)_List_of_All_Impaired Waters.pdf.

Kansas Department of Health and Environment, [undated], Kansas TMDL curve methodology: Bureau of Water, Watershed, Planning, Monitoring, and Assessment Section, accessed May 2012 at https:/www.kdheks.gov/tmdl/ basic.htm.

Kloesel, K., Bartush, B., Banner, J., Brown, D., Lemery, J., Lin, X., Loeffler, C., McManus, G., Mullens, E., NielsenGammon, J., Shafer, M., Sorensen, C., Sperry, S., Wildcat, D., and Ziolkowska, J., 2018, Southern Great Plains, in Reidmiller, D.R., Avery, C.W., Easterling, D.R., Kunkel, K.E., Lewis, K.L.M., Maycock, T.K., and Stewart, B.C., eds., Impacts, risks, and adaptation in the United States_-Fourth National Climate Assessment, volume II: Washington, D.C., U.S. Global Change Research Program, p. 987-1035, accessed September 2020 at https://doi.org/ 10.7930/NCA4.2018.CH23.

Kroll, S.A., and Oakland, H.C., 2019, A review of studies documenting the effects of agricultural best management practices on physiochemical and biological measures of stream ecosystem integrity: Natural Areas Journal, v. 39, no. 1, p. 58-77. [Also available at https://doi.org/10.3375/ 043.039.0105.]

Maidment, D.R., 1993, Handbook of hydrology: New York, McGraw-Hill, Inc. [variously paged].

Mastrandrea, M.D., and Mach, K.J., 2011, Treatment of uncertainties in IPCC Assessment Reports-Past approaches and considerations for the Fifth Assessment Report: Climatic Change, v. 108 , no. 4, p. 659-673. [Also available at https://doi.org/10.1007/s10584-011-0177-7.]
Mau, D.P., 2001, Sediment depositional trends and transport of phosphorus and other chemical constituents, Cheney Reservoir watershed, south-central Kansas: U.S. Geological Survey Water-Resources Investigations Report 2001-4085, 40 p. [Also available at https://doi.org/10.3133/wri014085.]

McKelvey, R.D., and Zavoina, W., 1975, A statistical model for the analysis of ordinal level dependent variables: The Journal of Mathematical Sociology, v. 4, no. 1, p. 103-120. [Also available at https://doi.org/10.1080/ 0022250X.1975.9989847.]

Medalie, L., Hirsch, R.M., and Archfield, S.A., 2012, Use of flow-normalization to evaluate nutrient concentration and flux changes in Lake Champlain tributaries, 1990-2009: Journal of Great Lakes Research, v. 38, p. 58-67. [Also available at https://doi.org/10.1016/j.jglr.2011.10.002.]

Menne, M.J., Durre, I., Korzeniewski, B., McNeal, S., Thomas, K., Yin, X., Anthony, S., Ray, R., Vose, R.S., Gleason, B.E., and Houston, T.G., 2012a, Global Historical Climatology Network-Daily (GHCN-Daily), version 3.26: National Oceanic and Atmospheric Administration, National Climate Data Center.

Menne, M.J., Durre, I., Vose, R.S., Gleason, B.E., and Houston, T.G., 2012b, An overview of the Global Historical Climatology Network-Daily database: Journal of Atmospheric and Oceanic Technology, v. 29, no. 7, p. 897-910. [Also available at https://doi.org/10.1175/ JTECH-D-11-00103.1.]

Moyer, D.L., Hirsch, R.M., and Hyer, K.E., 2012, Comparison of two regression-based approaches for determining nutrient and sediment fluxes and trends in the Chesapeake Bay watershed: U.S. Geological Survey Scientific Investigations Report 2012-5244, 118 p., accessed April 2020 at https://doi.org/10.3133/sir20125244.

Mueller, D.K., Schertz, T.L., Martin, J.D., and Sandstrom, M.W., 2015, Design, analysis, and interpretation of field quality-control data for water-sampling projects: U.S. Geological Survey Techniques and Methods, book 4, chap. C4, 54 p., accessed November 2019 at https://doi.org/ $10.3133 / \mathrm{tm} 4 \mathrm{C} 4$.

Murphy, J.C., Hirsch, R.M., and Sprague, L.A., 2013, Nitrate in the Mississippi River and its Tributaries, 1980-2010An update: U.S. Geological Survey Scientific Investigations Report 2013-5169, 31 p., accessed August 2020 at https://doi.org/10.3133/sir20135169.

National Oceanic and Atmospheric Administration, 2018, Global Historical Climatology Network-Daily (GHCNDaily), version 3: National Oceanic and Atmospheric Administration web page, accessed May 22, 2020, at https://doi.org/10.7289/V5D21VHZ. 
Oelsner, G.P., Sprague, L.A., Murphy, J.C., Zuellig, R.E., Johnson, H.M., Ryberg, K.R., Falcone, J.A., Stets, E.G., Vecchia, A.V., Riskin, M.L., De Cicco, L.A., Mills, T.J., and Farmer, W.H., 2017, Water-quality trends in the Nation's rivers and streams, 1972-2012-Data preparation, statistical methods, and trend results (ver. 2.0, October 2017): U.S. Geological Survey Scientific Investigations Report 2017-5006, 136 p., accessed November 2020 at https://doi.org/10.3133/sir20175006.

Oelsner, G.P., and Stets, E.G., 2019, Recent trends in nutrient and sediment loading to coastal areas of the conterminous U.S.-Insights and global context: The Science of the Total Environment, v. 654, p. 1225-1240. [Also available at https://doi.org/10.1016/j.scitotenv.2018.10.437.]

Otten, T.G., Graham, J.L., Harris, T.D., and Dreher, T.W., 2016, Elucidation of taste-and odor-producing bacteria and toxigenic cyanobacteria in a Midwestern drinking water supply reservoir by shotgun metagenomics analysis: Applied and Environmental Microbiology, v. 82, no. 17, p. 5410-5420. [Also available at https://dx.doi.org/10.1128/ AEM.01334-16.]

Painter, C.C., and Loving, B.L., 2015, U.S. Geological Survey quality-assurance plan for surface-water activities in Kansas, 2015: U.S. Geological Survey Open-File Report 2015-1074, 33 p., accessed November 2019 at https://doi.org/10.3133/ofr20151074.

Paulsen, G.M., 1997, Growth and development, in Wheat production handbook: Manhattan, Kans., Kansas State University, K-State Research and Extension Handbook C-529, p. 2-7, accessed November 2020 at https://bookstore.ksre.ksu.edu/pubs/C529.pdf.

Peterson, D.L., Whistler, J.L., Lomas, J.M., Dobbs, K.E., Jakubauskas, M.E., and Martinko, E.A., 2010, 2005 Kansas land cover patterns - Phase I: University of Kansas, Kansas Biological Survey Report 150, 29 p.

Pope, L.M., 1998, Watershed trend analysis and water-quality assessment using bottom-sediment cores from Cheney Reservoir, south-central Kansas: U.S. Geological Survey Water-Resources Investigations Report 98-4227, 24 p. [Also available at https://doi.org/10.3133/wri984227.]

Pope, L.M., and Milligan, C.R., 2000, Preliminary assessment of phosphorus transport in the Cheney Reservoir watershed, south-central Kansas, 1997-98: U.S. Geological Survey Water-Resources Investigations Report 2000-4023, 29 p. [Also available at https://doi.org/10.3133/wri004023.]

Pope, L.M., Milligan, C.R., and Mau, D.P., 2002, Historical contributions of phosphorus from natural and agricultural sources and implications for stream water quality, Cheney Reservoir watershed, south-central Kansas: U.S. Geological Survey Water-Resources Investigations Report 2002-4021, 25 p. [Also available at https://doi.org/10.3133/wri024021.]
Porterfield, G., 1972, Computation of fluvial-sediment discharge: U.S. Geological Survey Techniques of Water Resources Investigations, book 3, chap C3, 66 p. [Also available at https://doi.org/10.3133/twri03C3.]

R Core Team, 2019, R-A language and environment for statistical computing: Vienna, Austria, R Foundation for Statistical Computing, accessed October 2019 at https://www.R-project.org/.

Rasmussen, T.J., Bennett, T.J., Stone, M.L., Foster, G.M., Graham, J.L., and Putnam, J.E., 2014, Quality-assurance and data-management plan for water-quality activities in the Kansas Water Science Center, 2014: U.S. Geological Survey Open-File Report 2014-1233, 41 p., accessed November 2019 at https://doi.org/10.3133/ofr20141233.

Rasmussen, P.P., Gray, J.R., Glysson, G.D., and Ziegler, A.C., 2009, Guidelines and procedures for computing time-series suspended-sediment concentrations and loads from in-stream turbidity-sensor and streamflow data: U.S. Geological Survey Techniques and Methods, book 3, chap. C4, 52 p. [Also available at https://doi.org/10.3133/tm3C4.]

Rasmussen, T.J., Lee, C.J., and Ziegler, A.C., 2008, Estimation of constituent concentrations, loads, and yields in streams of Johnson County, northeast Kansas, using continuous water quality monitoring and regression models, October 2002 through December 2006: U.S. Geological Survey Scientific Investigations Report 2008-5014, 103 p. [Also available at https://doi.org/10.3133/sir20085014.]

Rasmussen, T.J., Ziegler, A.C., and Rasmussen, P.P., 2005, Estimation of constituent concentrations, densities, loads, and yields in lower Kansas River, northeast Kansas, using regression models and continuous water-quality monitoring, January 2000 through December 2003: U.S. Geological Survey Scientific Investigations Report 2005-5165, 117 p. [Also available at https://doi.org/10.3133/sir20055165.]

Rockers, J.J., Ratcliff, I., Dowd, L.W., and Bouse, E.F., 1966, Soil survey of Reno County, Kansas: Washington, D.C., U.S. Government Printing Office, 72 p.

Sauer, V.B., and Turnipseed, D.P., 2010, Stage measurement at gaging stations: U.S. Geological Survey Techniques and Methods, book 3, chap. A7, 45 p., accessed November 2019 at https://doi.org/10.3133/tm3A7.

Shafer, M., Ojima, D., Antle, J.M., Kluck, D., McPherson, R.A., Petersen, S., Scanlon, B., and Sherman, K., 2014, Great Plains, in Melillo, J.M., Richmond, T.C., and Yohe, G.W., eds., Climate change impacts in the United StatesThe Third National Climate Assessment: U.S. Global Change Research Program, p. 441-461. [Also available at https://doi.org/10.7930/J0D798BC.] 
Smith, V.H., Sieber-Denlinger, J., deNoyelles, F., Jr., Campbell, S., Pan, S., Randtke, S.J., Blain, G.T., and Strasser, V.A., 2002, Managing taste and odor problems in a eutrophic drinking water reservoir: Lake and Reservoir Management, v. 18, no. 4, p. 319-323. [Also available at https://doi.org/10.1080/07438140209353938.]

Sprague, L.A., Hirsch, R.M., and Aulenbach, B.T., 2011, Nitrate in the Mississippi River and its tributaries, 1980 to 2008-Are we making progress?: Environmental Science \& Technology, v. 45, no. 17, p. 7209-7216. [Also available at https://doi.org/10.1021/es201221s.]

Stone, M.L., Graham, J.L., and Gatotho, J.W., 2013a, Continuous real-time water-quality monitoring and regression analysis to compute constituent concentrations and loads in the North Fork Ninnescah River upstream from Cheney Reservoir, south-central Kansas, 1999-2012: U.S. Geological Survey Scientific Investigations Report 2013-5071, 44 p., accessed November 2020 at https://doi.org/10.3133/sir20135071.

Stone, M.L., Graham, J.L., and Gatotho, J.W., 2013b, Model documentation for relations between continuous real-time and discrete water-quality constituents in Cheney Reservoir near Cheney, Kansas, 2001-2009: U.S. Geological Survey Open-File Report 2013-1123, 100 p., accessed November 2020 at https://doi.org/10.3133/ofr20131123.

Stone, M.L., Graham, J.L., and Ziegler, A.C., 2009, Twelve years of monitoring phosphorus and suspended-solids concentrations and yields in the North Fork Ninnescah River above Cheney Reservoir, south-central Kansas 1997-2008: U.S. Geological Survey Fact Sheet 2009-3073, 4 p. [Also available at https://doi.org/10.3133/fs20093073.]

Stone, M.L., Juracek, K.E., Graham, J.L., and Foster, G.M., 2015, Quantifying suspended sediment loads delivered to Cheney Reservoir, Kansas-Temporal patterns and management implications: Journal of Soil and Water Conservation, v. 70, no. 2, p. 91-100. [Also available at https://doi.org/ 10.2489/jswc.70.2.91.]

Stone, M.L., Klager, B.J., and Ziegler, A.C., 2019, Waterquality and geochemical variability in the Little Arkansas River and Equus Beds aquifer, south-central Kansas, 2001-16: U.S. Geological Survey Scientific Investigations Report 2019-5026, 79 p., accessed June 2020 at https://doi.org/10.3133/sir20195026.

Stumm, W., and Morgan, J.J., 1996, Aquatic chemistryChemical equilibria and rates in natural waters ( $3 \mathrm{~d}$ ed.): John Wiley \& Sons, 1,040 p.

Taylor, W.D., Losee, R.F., Torobin, M., Izaguirre, G., Sass, D., Khiari, D., and Atasi, K., 2005, Early warning and management of surface water taste-and-odor events: AWWA Research Foundation, 373 p.
Tobin, J., 1958, Estimation of relationships for limited dependent variables: Econometrica, v. 26, no. 1, p. 24-36. [Also available at https://doi.org/10.2307/1907382.]

Turnipseed, D.P., and Sauer, V.B., 2010, Discharge measurements at gaging stations: U.S. Geological Survey Techniques and Methods, book 3, chap. A8, 87 p., accessed November 2019 at https://doi.org/10.3133/tm3A8.

U.S. Department of Agriculture, 2018a, Kansas crop progress and condition: National Agricultural Statistics Service news release, October 9, 2018, accessed October 2020 at https://www.nass.usda.gov/Statistics_by_State/Kansas/ Publications/Crop_Progress_and_Condition/2018/KSweekly1009.pdf.

U.S. Department of Agriculture, 2018b, Kansas crop progress and condition: National Agricultural Statistics Service news release, November 19, 2018, accessed October 2020 at https://www.nass.usda.gov/Statistics_by_State/Kansas/ Publications/Crop_Progress_and_Condition/2018/KSweekly1119.pdf.

U.S. Environmental Protection Agency, 2000, Nutrient criteria technical guidance manual-Rivers and streams: Washington, D.C., U.S. Environmental Protection Agency, Office of Water, EPA-822-B-00-002, 126 p. plus appendixes. [Also available at https://nepis.epa.gov/Exe/ ZyPDF.cgi/20003CVP.PDF?Dockey=20003CVP.PDF.]

U.S. Environmental Protection Agency, 2001, Ambient water quality criteria recommendations-Rivers and streams in nutrient Ecoregion V: Washington, D.C., U.S. Environmental Protection Agency, Office of Water, EPA 822-B-01-014, 29 p. plus appendixes. [Also available at https://www.epa.gov/sites/production/files/documents/ rivers5.pdf.]

U.S. Environmental Protection Agency, 2002, Summary table for the nutrient criteria documents: U.S. Environmental Protection Agency, 3 p., accessed March 2011 at https://water.epa.gov/scitech/swguidance/standards/criteria/ nutrients/upload/2007_09_27_criteria_nutrient_ecoregions_ sumtable.pdf.

U.S. Environmental Protection Agency, 2005, Occurrence assessment for the final stage 2 disinfectants and disinfection byproducts rule: Washington, D.C., U.S. Environmental Protection Agency, Office of Water, EPA 815-R-05-011 [variously paged]. [Also available at https://nepis.epa.gov/ Exe/ZyPDF.cgi?Dockey=P1005ED2.txt.]

U.S. Environmental Protection Agency, 2009, National primary drinking water regulations: U.S. Environmental Protection Agency, EPA 816-F-09-004, 7 p., accessed October 2017 at https://www.epa.gov/sites/production/files/ 2016-06/documents/npwdr_complete_table.pdf. 
U.S. Environmental Protection Agency, 2016a, National lakes assessment 2012-A collaborative survey of lakes in the United States: Washington, D.C., U.S. Environmental Protection Agency, Office of Water, EPA 841-R-16-113, $35 \mathrm{p}$. [Also available at https://www.epa.gov/sites/ production/files/2016-12/documents/nla_report_dec_ 2016.pdf.]

U.S. Environmental Protection Agency, 2016b, National rivers and streams assessment 2008-2009-A collaborative survey: Washington, D.C., U.S. Environmental Protection Agency, Office of Water, EPA 841-R-16-007, 116 p. [Also available at https://www.epa.gov/sites/production/files/ 2016-03/documents/nrsa_0809_march_2_final.pdf.]

U.S. Environmental Protection Agency, 2017, National water quality inventory-Report to congress: Washington, D.C., U.S. Environmental Protection Agency, Office of Water, EPA 841-R-16-011, 21 p. [Also available at https:/www.epa.gov/sites/production/files/2017-12/ documents/305brtc_finalowow_08302017.pdf.]

U.S. Geological Survey, 2006, Collection of water samples (ver. 2.0, September 2006): U.S. Geological Survey Techniques of Water Resources Investigations, book 9 , chap. A4 [variously paged]. [Also available at https://doi. org/10.3133/twri09A4.]

U.S. Geological Survey, 2020, USGS water data for the Nation: U.S. Geological Survey National Water Information System database, accessed April 20, 2020, at https://doi.org/ 10.5066/F7P55KJN.

Wagner, R.J., Boulger, R.W., Jr., Oblinger, C.J., and Smith, B.A., 2006, Guidelines and standard procedures for continuous water-quality monitors - Station operation, record computation, and data reporting: U.S. Geological Survey Techniques and Methods, book 1, chap D3, 51 p. plus 8 attachments. [Also available at https://doi.org/10.3133/ tm1D3.]

Walton, G., 1951, Survey of literature relating to infant methemoglobinemia due to nitrate-contaminated water: American Journal of Public Health and the Nation's Health, v. 41, no. 8, pt. 1, p. 986-996. [Also available at https://www.ncbi.nlm.nih.gov/pme/articles/PMC1525621/.]

Ward, M.H., deKok, T.M., Levallois, P., Brender, J., Gulis, G., Nolan, B.T., and vanDerslice, J., 2005, Workgroup reportDrinking-water nitrate and health-Recent findings and research needs: Environmental Health Perspectives, v. 113, no. 11, p. 1607-1614. [Also available at https://doi.org/ 10.1289/ehp.8043.]

Wetzel, R.G., 2001, Limnology (3d ed.): San Diego, Calif., Academic Press, 1,006 p.
Wilde, F.D., ed., 2008, General information and guidelines: U.S. Geological Survey Techniques of Water-Resources Investigations, book 9, chap. A6.0, 27 p., accessed November 2019 at https://doi.org/10.3133/twri09A6.0.

Wilde, F.D., ed., variously dated, Field measurements: U.S. Geological Survey Techniques of Water-Resources Investigations, book 9, chap. A6, 9 p., accessed September 2016 at https://pubs.water.usgs.gov/twri9A6/.

Yang, L., Jin, S., Danielson, P., Homer, C., Gass, L., Bender, S.M., Case, A., Costello, C., Dewitz, J., Fry, J., Funk, M., Granneman, B., Liknes, G.C., Rigge, M., and Xian, G., 2018, A new generation of the United States National Land Cover Database - Requirements, research priorities, design, and implementation strategies: ISPRS Journal of Photogrammetry and Remote Sensing, v. 146, p. 108-123. [Also available at https://doi.org/10.1016/ j.isprsjprs.2018.09.006.]

YSI Incorporated, 2007, YSI 6136 turbidity sensor: YSI Incorporated, 2 p., accessed November 2019 at https://www.ysi.com/File\%20Library/Documents/ Specification\%20Sheets/E56-6136-Turbidity-Sensor.pdf.

YSI Incorporated, 2012a, 6-series multiparameter water quality sondes-User manual, revision J: YSI Incorporated, 379 p., accessed November 2019 at https://www.ysi.com/ File\%20Library/Documents/Manuals/069300-YSI-6-SeriesManual-RevJ.pdf.

YSI Incorporated, 2012b, EXO water quality field sensorsFeatures, specifications, and comparability to YSI 6-series sensors, revision B: YSI Incorporated, 14 p., accessed November 2019 at https://www.exowater.com/media/pdfs/ EXO-6Series-Sensor-Comparison.pdf.

YSI Incorporated, 2019, Turbidity units and calibration solutions-YSI turbidity sensors: Yellow Springs, Ohio, YSI Incorporated, 2 p., accessed November 2019 at https://www.ysi.com/File\%20Library/Documents/ Technical\%20Notes/T627_Turbidity_Units_and Calibration_Solutions.pdf.

Zeller, D.E., 1968, The stratigraphic succession in KansasState Geological Survey of Kansas Bulletin 189: Lawrence, Kans., University of Kansas Publications, 81 p. 


\section{Appendixes 1-24}

The model archive summaries, including previous model versions, are provided in appendixes $1-18$. The Weighted Regressions on Time, Discharge, and Season model evaluation and Weighted Regressions on Time, Discharge, and Season bootstrap test output for each constituent are provided in appendixes 19-24. Each appendix is available for download at https://doi.org/10.3133/sir20215006. 

For more information about this publication, contact: Director, USGS Kansas Water Science Center

1217 Biltmore Drive

Lawrence, KS 66049

785-842-9909

For additional information, visit: https://www.usgs.gov/centers/kswsc

Publishing support provided by the

Rolla Publishing Service Center 


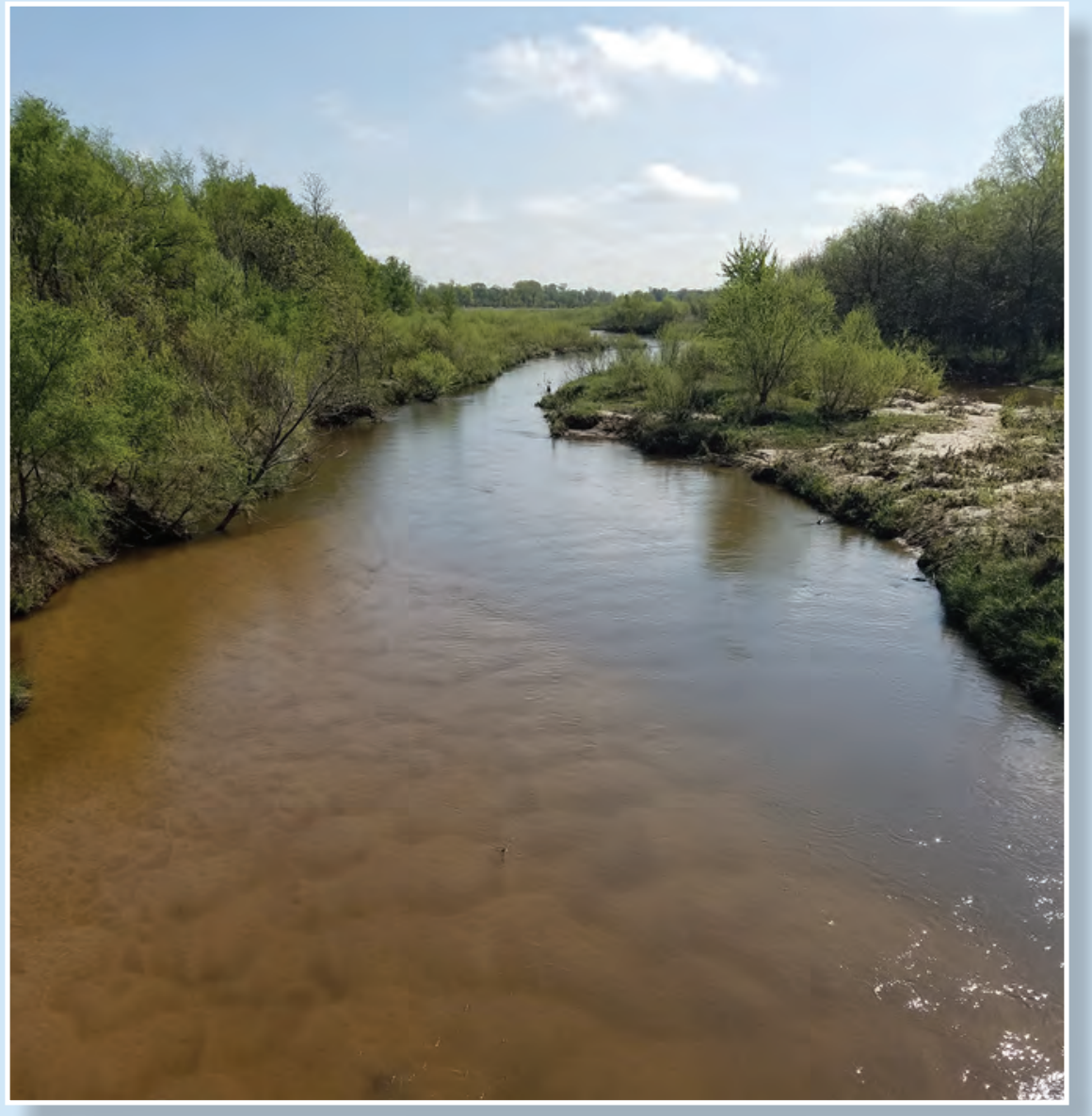

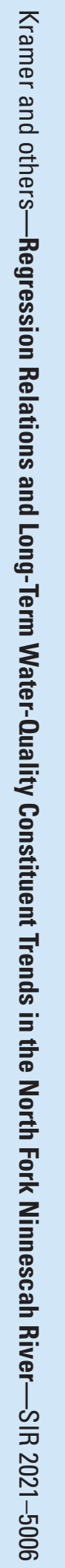

